\title{
UMKM Goes Online Regulasi E-Commerce
}




\section{UU No 28 tahun 2014 tentang Hak Cipta}

\section{Fungsi dan sifat hak cipta Pasal 4}

Hak Cipta sebagaimana dimaksud dalam Pasal 3 huruf a merupakan hak eksklusif yang terdiri atas hak moral dan hak ekonomi.

Pembatasan Pelindungan Pasal 26

Ketentuan sebagaimana dimaksud dalam Pasal 23, Pasal 24, dan Pasal 25 tidak berlaku terhadap:

i. Penggunaan kutipan singkat Ciptaan dan/atau produk Hak Terkait untuk pelaporan peristiwa aktual yang ditujukan hanya untuk keperluan penyediaan informasi aktual;

ii. Penggandaan Ciptaan dan/atau produk Hak Terkait hanya untuk kepentingan penelitian ilmu pengetahuan;

iii. Penggandaan Ciptaan dan/atau produk Hak Terkait hanya untuk keperluan pengajaran, kecuali pertunjukan dan Fonogram yang telah dilakukan Pengumuman sebagai bahan ajar; dan

iv. Penggunaan untuk kepentingan pendidikan dan pengembangan ilmu pengetahuan yang memungkinkan suatu Ciptaan dan/atau produk Hak Terkait dapat digunakan tanpa izin Pelaku Pertunjukan, Produser Fonogram, atau Lembaga Penyiaran.

\section{Sanksi Pelanggaran Pasal 113}

1. Setiap Orang yang dengan tanpa hak melakukan pelanggaran hak ekonomi sebagaimana dimaksud dalam Pasal 9 ayat (1) huruf i untuk Penggunaan Secara Komersial dipidana dengan pidana penjara paling lama 1 (satu) tahun dan/atau pidana denda paling banyak Rp100.000.000 (seratus juta rupiah).

2. Setiap Orang yang dengan tanpa hak dan/atau tanpa izin Pencipta atau pemegang Hak Cipta melakukan pelanggaran hak ekonomi Pencipta sebagaimana dimaksud dalam Pasal 9 ayat (1) huruf c, huruf d, huruf f, dan/atau huruf h untuk Penggunaan Secara Komersial dipidana dengan pidana penjara paling lama 3 (tiga) tahun dan/atau pidana denda paling banyak Rp500.000.000,00 (lima ratus juta rupiah). 


\title{
UMKM Goes Online Regulasi E-Commerce
}

\author{
Ni Putu Suci Meinarni, S.H., LL.M. \\ Ida Bagus Ari Indra Iswara, S.Kom., M.Kom. \\ I Nyoman Saputra Wahyu Wijaya, S.Kom., M.Cs. \\ Ayu Gede Willdahlia, S.E., M.M.
}

\section{deepublish}




\title{
UMKM GOES ONLINE REGULASI E-COMMERCE
}

\author{
Ni Putu Suci Meinarni ... [et al.]
}

Desain Cover :

Herlambang Rahmadhani

Tata Letak :

\section{Haris Ari Susanto}

Ukuran :

viii, 99 hlm, Uk: $15.5 \times 23 \mathrm{~cm}$

ISBN :

No ISBN

Cetakan Pertama :

Bulan 2020

Hak Cipta 2020, Pada Penulis

Isi diluar tanggung jawab percetakan

Copyright (C) 2020 by Deepublish Publisher

All Right Reserved

Hak cipta dilindungi undang-undang

Dilarang keras menerjemahkan, memfotokopi, atau memperbanyak sebagian atau seluruh isi buku ini tanpa izin tertulis dari Penerbit.

\section{PENERBIT DEEPUBLISH}

(Grup Penerbitan CV BUDI UTAMA)

Anggota IKAPI (076/DIY/2012)

Jl.Rajawali, G. Elang 6, No 3, Drono, Sardonoharjo, Ngaglik, Sleman

Jl.Kaliurang Km.9,3 - Yogyakarta 55581

Telp/Faks: (0274) 4533427

Website: www.deepublish.co.id

www.penerbitdeepublish.com

E-mail: cs@deepublish.co.id 


\section{KATA PENGANTAR}

Masyarakat pada era revolusi industri 4.0 menyadari pertumbuhan ekonomi yang sangat dinamis dan progresif. Fenomena tersebut harus dibarengi dengan skill serta kompetensi mumpuni didalam berbagai bidang. Salah satunya adalah bidang perekonomian. Telah terjadi pergerakan yang masiv baik dalam skala mikro maupun makro terkait pertumbuhan ekonomi tersebut.

Kekhawatiran akan culture shock pada kalangan masyarakat pelaku ekonomi mikro pun muncul. Keberadaan teknologi sebagai penunjang roda perekonomian selain memberikan dampak yang positif memungkinkan pula timbulnya potensi pelanggaran terkait regulasi perdagangan. Dunia digital merupakan wilayah tanpa batas. Dimana setiap orang yang berada didalamnya harus bersedia mempersiapkan diri atas berbagai pengetahuan, paling tidak pengetahuan umum terkait suatu topik. Karena bisa saja terjadi informasi yang diterima oleh pengguna belum tentu sesuai dengan fakta dan realita. Dan buku ini disusun dalam rangka memberikan pengetahuan terkait regulasi e-commerce.

Penyusunan buku ini pada dasarnya bertujuan untuk memberikan pengetahuan mengenai gambaran umum roda perekonomian lokal, nasional maupun global. Penyajian gambar dan literasi di dalam buku ini diharapkan dapat memberikan pengetahuan baru bagi pembaca.

Akhir kata, tidak lupa kami panjatkan puji syukur kehadapan Ida Sang Hyang Wasa karena atas restu beliau buku ini dapat 
terselesaikan. Serta kami ucapkan terima kasih kepada para pihak yang turut mendukung terealisasinya buku ini, diantaranya: Direktorat Riset Pengabdian Masyarakat (DRPM) Kementerian Riset, Teknologi dan Pendidikan Tinggi Indonesia, Lembaga Penelitian dan Pengabdian Masyarakat STMIK STIKOM Indonesia, Riko Kaliadrem sebagai mitra dalam kegiatan Pengabdian Kepada Masyarakat, serta pihak-pihak yang tidak dapat kami sebutkan satu persatu.

Denpasar, Desember 2020

Penulis 


\section{DAFTAR ISI}

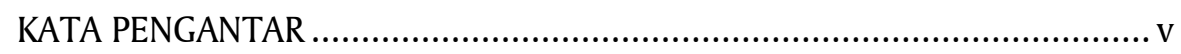

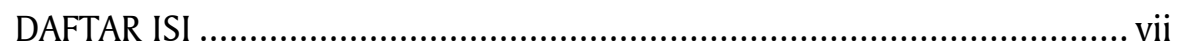

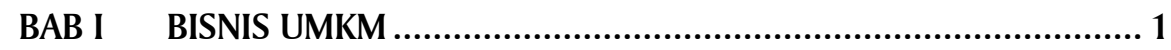

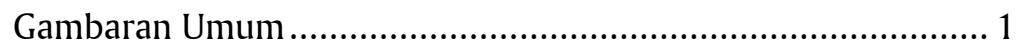

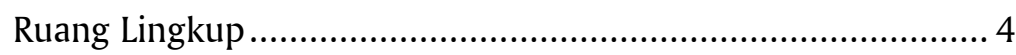

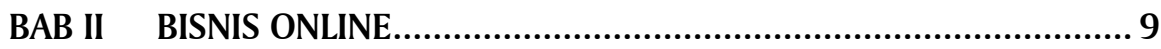

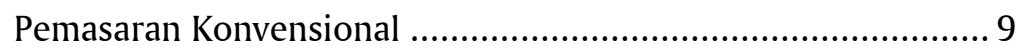

Model Penjualan Digital........................................................ 12

BAB III REGULASI TERKAIT UMKM DAN E-COMMERCE ...................... 19

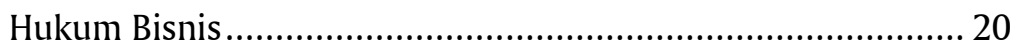

Tata Cara Pendaftaran Usaha ..................................................... 28

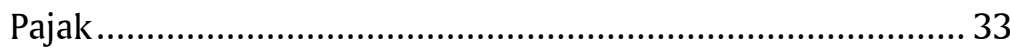

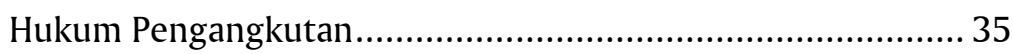

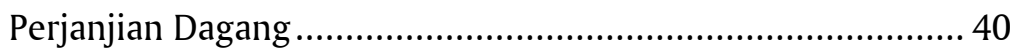

Perlindungan Konsumen ..................................................... 44

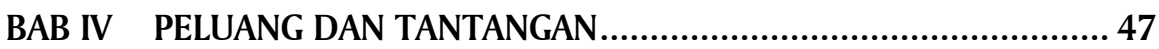

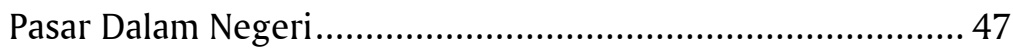

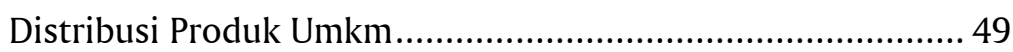

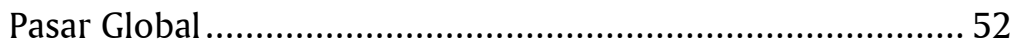

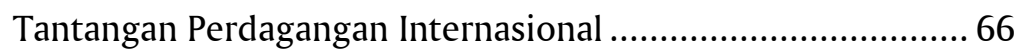

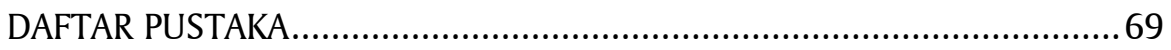

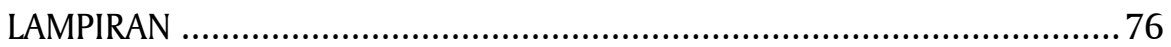

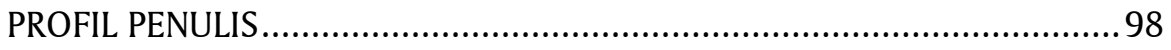


viii $\square$ Ni Putu Suci Meinarni ... [et al.] 


\section{BAB I \\ BISNIS UMKM}

\section{GAMBARAN UMUM}

Buku ini disusun untuk memberikan pemahaman umum mengenai bagaimana masyarakat Indonesia dapat memulai bisnis/usaha. Terkait dengan era revolusi industri 4.0, usaha yang dimaksudkan pada buku ini merujuk pada konteks usaha yang bergerak pada ranah digital. Untuk itu, hal paling mendasar yang perlu diketahui adalah pengertian umum tentang usaha dan badan usaha. Badan Usaha adalah perusahaan perseorangan atau perusahaan persekutuan, baik yang berbadan hukum maupun yang tidak berbadan hukum(tertuang pada Pasal 1 ayat 22, UU ITE).(UU Informasi Dan Transaksi Elektronik, 2016) Badan usaha sebagai sebuah entitas hukum yang dalam kegiatan operasionalnya bertujuan untuk mendapatkan keuntungan (laba). Hasil produksi dari kegiatan operasional seyogyanya dapat terdistribusi dengan baik agar sebuah usaha dapat berjalan dengan lancar.

Salah satu bentuk badan usaha yang tumbuh dan berkembang ditengah-tengah masyarakat Indonesia adalah Usaha Mikro, Kecil dan Menengah (UMKM). Kegiatan UMKM diminati masyarakat belakangan ini karena usaha ini disebut oleh para ahli sebagai tulang punggung dari ekonomi yang sehat. Menurut International Council for Small Business (ICSB), 90\% dari bisnis merupakan UMKM, menyumbang rata-rata 60$70 \%$ dari total lapangan pekerjaan dan 50\% dari PDB. Sederhananya, UMKM memiliki peran signifikan dalam mendorong pertumbuhan ekonomi, menyediakan peluang kerja, dan menciptakan pasar yang 
seimbang. UMKM juga menciptakan persaingan dan dapat meningkatkan produktivitas lintas industri. Dengan memanfaatkan celah yang ada atau menciptakan target pasar mereka sendiri, UMKM seringkali 'memaksa' bisnis yang lebih besar untuk meningkatkan inovasi dan daya saing mereka.(Lalamove, 2020)

Selain itu, selama krisis terjadi UMKM sebagai katup pengaman bagi perekonomian nasional. Hal ini terasa sekali ketika Indonesia dilanda krisis multidimensi, ketika usaha skala besar masih berkutat dengan masalah ketergantungan pada pinjaman luar negeri, yang makin membengkak pada saat krisis. Pengembangan UMKM yang fleksibel justru menikmati kondisi krisis moneter khususnya bagi usaha yang bergerak yang berorientasi pasar luar negeri (ekspor). Ketika terjadi krisis, maka merekalah yang menggerakkan ekonomi Indonesia.(Abdurohim, 2020)

Ada empat karakteristik mengapa UMKM mampu bertahan dalam krisis:(Basri, 2003)

1. Sebagian besar UMKM menghasilkan barang-barang konsumsi (consumer goods) khususnya yang tidak tahan lama (non-durable consumer goods). Kelompok barang ini dicirikan apabila terjadi peningkatan pendapatan masyarakat, permintaan terhadap barang ini tidak meningkat banyak. Begitu juga sebaliknya, jika pendapatan masyarakat merosot sebagai akibat dari krisis, maka permintaan pun tidak berkurang banyak.

2. Mayoritas UMKM lebih mengandalkan pada pembiayaan nonbanking dalam aspek pendanaan usaha. Saat perbankan terpuruk akibat krisis, usaha ini tidak terpengaruh.

3. Umumnya usaha ini melakukan spesialisasi yang ketat, yaitu hanya memproduksi barang atau jasa tertentu (kebalikan dari konglomerasi). UMKM mengarah pada pasar persaingan sempurna dimana kondisi keluar-masuk pasar kerap terjadi spesialisasi dan struktur pasar tersebut membuat UMKM cenderung fleksibel dalam memilih dan berganti usaha.

4. Usaha kecil informal baru muncul karena banyaknya pemutusan hubungan kerja dimasa-masa krisis. Selain itu, daya tahan UMKM tercipta karena mereka tidak banyak memiliki ketergantungan pada 
faktor eksternal, seperti utang dalam valuta asing dan bahan baku impor dalam melakukan kegiatan usahanya, sebab umumnya UMKM menggunakan bahan baku dari sumber alam lokal.

Pada 26 Februari 2019, gerakan UMKM Go Online 2019 resmi diluncurkan Kementerian Komunikasi dan Informatika. Gerakan tersebut mewakili suara UMKM terkait pemerataan akses pasar melalui platform digital.(Sari, Anggri Puspita; Anggraini, Dina Dewi; Sari, Marlynda Happy Nurmalita; Gandasari, Dyah; Siagian, Valentine; Septarini, Ri Sabti; Tjiptadi, Diena Dwidienawati; Sulaiman, Oris Krianto; Munsarif, Muhammad; Siregar, Prima Andreas; Nugraha, Nur Arif; Sima, 2020) Dari sisi potensi pasar ada platform digital, pertumbuhan pengguna internet di Indonesia juga diikuti dengan pertumbuhan UMKM. Data Badan Pusat Statistik Indonesia (BPS) menunjukkan pasca krisis ekonomi 1997-1998, jumlah UMKM tidak menurun dan justru meningkat, bahkan mampu menyerap lebih dari 85 juta hingga 107 juta pekerja hingga tahun 2012.(Syahputro, 2020)

Dengan berbagai potensi yang dimiliki UMKM, buku ini diharapkan dapat memberikan gambaran mengenai UMKM di ranah digital sehingga para pelaku di industri tersebut dapat memaksimalkan potensi bisnisnya bahkan mampu mengembangkan usaha tersebut. Begitu pula bagi masyarakat lainnya yang mulai melirik potensi dari UMKM, semoga semakin termotivasi untuk menciptakan ruang kerja serta kreativitasnya melalui UMKM. 


\section{RUANG LINGKUP}

Usaha Mikro, Kecil dan Menengah menurut Undang-Undang Nomor 20 Tahun 2008 didefinisikan sebagai berikut:

\section{Usaha Mikro}

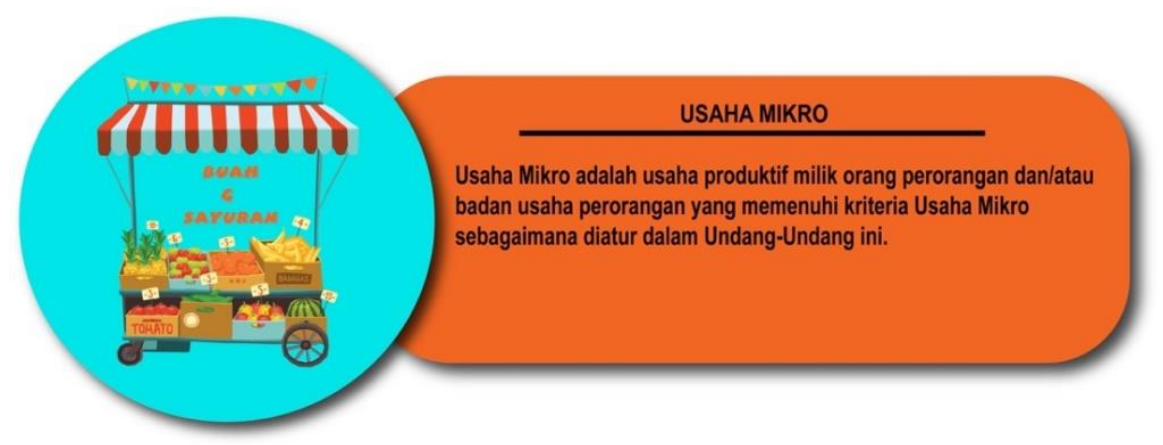

Karakteristik usaha mikro yaitu:(Rijanto, Ahmad; Rahayuningsih, 2020)

1. Jenis barang/komoditi usahanya tidak selalu tetap, sewaktu-waktu dapat berganti.

2. Tempat usahanya tidak selalu menetap, sewaktu-waktu dapat pindah tempat.

3. Belum melakukan administrasi keuangan yang sederhana sekalipun, dan tidak memisahkan keuangan keluarga dengan keuangan usaha.

4. Sumber daya manusianya (pengusahanya) belum memiliki jiwa wirausaha yang memadai.

5. Tingkat Pendidikan rata-ratarelatif sangat rendah.

6. Umumnya belum akses kepada perbankan, namun sebagian sudah akses ke Lembaga keuangan non bank.

7. Umumnya tidak memiliki izin usaha atau persyaratan legalitas lainnya termasuk NPWP.

Contoh Usaha Mikro:

1. Usaha tani pemilik dan penggarap perorangan, peternak, nelayan dan pembudidaya;

2. Industri makanan dan minuman, industri meubel, pengolahan kayu dan rotan, industri pelaku usaha mikro besi pembuat alat-alat;

$4 \square$ Ni Putu Suci Meinarni ... [et al.] 
3. Usaha perdagangan kaki lima serta pedagang di pasar;

4. Peternakan ayam, itik dan perikanan

5. Usaha jasa-jasa seperti perbengkelan, salon kecantikan, ojek dan penjahit (konveksi).

\section{Usaha Kecil}

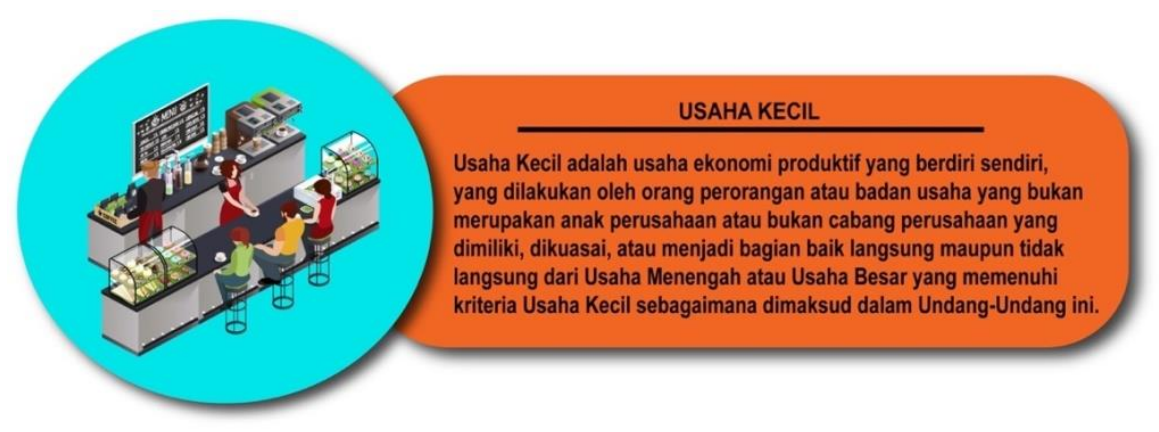

Karakteristik usaha kecil, diantaranya adalah:(Rijanto, Ahmad; Rahayuningsih, 2020)

1. Jenis barang/komoditi yang diusahakan umumnya sudah tetap tidak gampang berubah;

2. Lokasi/tempat usaha umumnya sudah menetap tidak berpindahpindah;

3. Pada umumnya sudah melakukan administrasi keuangan walau masih sederhana, keuangan perusahaan sudah mulai dipisahkan dengan keuangan keluarga, sudah membuat neraca usaha;

4. Sudah memiliki izin usaha dan persyaratan legalitas lainnya termasuk NPWP;

5. Sumberdaya manusia (pengusaha) memiliki pengalaman dalam berwirausaha;

6. Sebagian sudah akses ke perbankan dalam keperluan modal;

7. Sebagian besar belum dapat membuat manajemen usaha dengan baik seperti business palnning. 
Contoh Usaha Kecil:

1. Usaha tani sebagai pemilik tanah perorangan yang memiliki tenaga kerja;

2. Pedagang dipasar grosir (agen) dan pedagang pengumpul lainnya;

3. Pengrajin industri makanan dan minuman, industri meubel, kayu dan rotan, industri alat-alat rumah tangga, industri pakaian jadi dan industri kerajinan tangan;

4. Peternak ayam, itik dan perikanan;

5. Koperasi berskala kecil.

\section{Usaha Menengah}

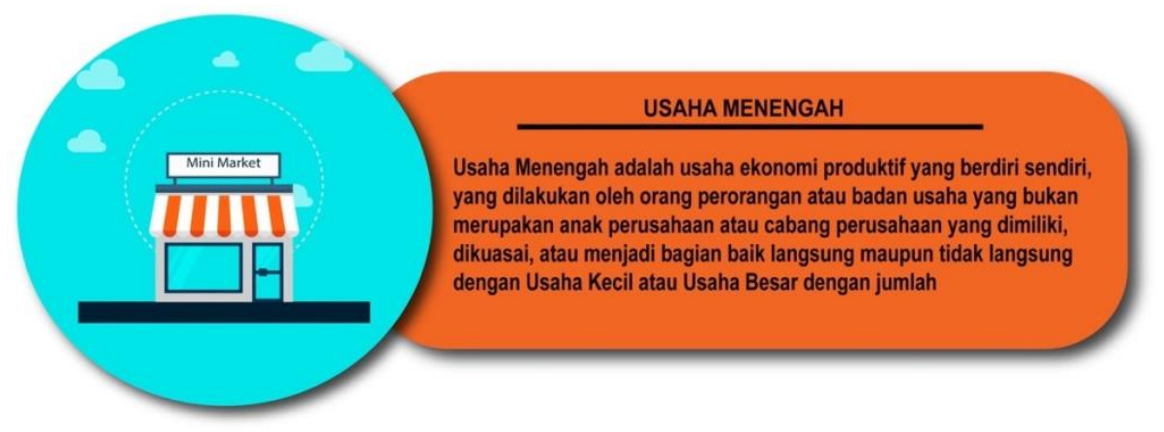

Karakteristik usaha menengah, sebagai berikut:(Rijanto, Ahmad; Rahayuningsih, 2020)

1. Umumnya memiliki manajemen dan organisasi yang lebih baik, lebih teratur bahkan lebih modern, dengan pembagian tugas yang jelas antara lain, bagian keuangan, bagian pemasaran dan bagian produksi;

2. Telah melakukan manajemen keuangan dengan menerapkan sistem akuntansi dengan teratur, sehingga memudahkan untuk auditing dan penilaian atau pemeriksaan termasuk oleh perbankan;

3. Telah melakukan aturan atau pengelolaan dan organisasi perburuhan, telah ada jamsostek, pemeliharaan kesehatan dll;

4. Sudah memiliki segala persyaratan legalitas antara lain izin tetangga, izin usaha, izin tempat, NPWP, upaya pengelolaan lingkungan dll;

5. Sudah akses kepada sumber-sumber pendanaan perbankan;

6. Pada umumnya telah memiliki sumber daya manusia yang terlatih dan terdidik 
Contoh usaha menengah antara lain:

1. Usaha pertanian, peternakan, perkebunan, kehutanan skala menengah;

2. Usaha perdagangan (grosir) termasuk expor dan impor;

3. Usaha jasa EMKL (Ekspedisi Muatan Kapal Laut), garmen dan jasa transportasi taxi dan bus antar propinsi;

4. Usaha industri makanan dan minuman, elektronik dan logam;

5. Usaha pertambangan batu gunung untuk konstruksi dan marmer buatan.

Usaha Mikro, Kecil, dan Menengah berasaskan:
a. Kekeluargaan
b. Demokrasi Ekonomi
c. Kebersamaan
d. Efisiensi Berkeadilan
e. Berkelanjutan
f. Berwawasan lingkungan
g. Kemandirian
h. Keseimbangan Kemajuan dan
i. Kesatuan Ekonomi Nasional.

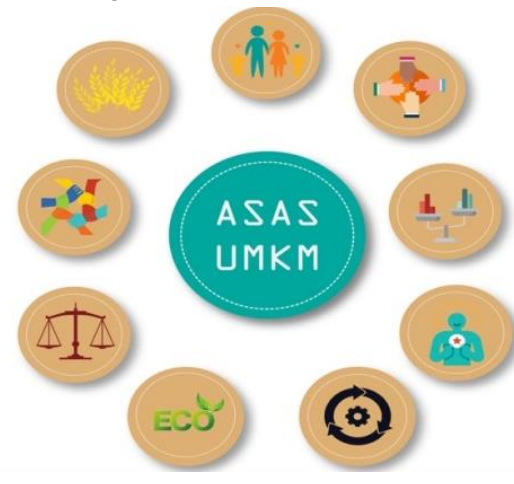

Pentingnya UMKM bagi pertumbuhan ekonomi bangsa(Lalamove, 2020)

\begin{tabular}{|c|c|}
\hline $\begin{array}{l}\text { Membuka } \\
\text { Lapangan Kerja }\end{array}$ & $\begin{array}{l}\text { Dengan banyaknya jumlah UMKM, artinya semakin banyak } \\
\text { juga tenaga kerja yang dibutuhkan. Menurut data } \\
\text { Kementerian Koperasi dan UKM, usaha kecil dan menengah } \\
\text { mampu menyerap } 89,17 \text { persen tenaga kerja domestik. } \\
\text { Meningkatnya lapangan pekerjaan dapat membantu } \\
\text { mengurangi angka pengangguran dan kemiskinan, khususnya } \\
\text { bagi masyarakat lokal. } \\
\text { Tak hanya itu, pekerja UMKM dikatakan memiliki tingkat } \\
\text { kepuasan kerja yang lebih tinggi. Hal ini dikarenakan dalam } \\
\text { bisnis yang skalanya lebih kecil, pekerja lebih bisa } \\
\text { merasakan dampak dari kontribusi mereka secara langsung } \\
\text { sehingga mereka pun merasa lebih puas. }\end{array}$ \\
\hline $\begin{array}{l}\text { Meningkatkan } \\
\text { Daya Saing }\end{array}$ & $\begin{array}{l}\text { Adanya UMKM artinya mereka memiliki target pasarnya } \\
\text { sendiri secara spesifik dengan produk yang juga mereka } \\
\text { kontrol secara independen. Dengan cakupan fokus yang lebih } \\
\text { kecil, mereka bisa menekan biaya operasional dan }\end{array}$ \\
\hline
\end{tabular}




\begin{tabular}{|c|c|}
\hline \multicolumn{2}{|c|}{ Pentingnya UMKM bagi pertumbuhan ekonomi bangsa(Lalamove, 2020) } \\
\hline & $\begin{array}{l}\text { menawarkan harga produk yang lebih murah. } \\
\text { Selain itu, mereka juga lebih mudah untuk berinovasi dan } \\
\text { beradaptasi dengan lebih cepat dibandingkan bisnis berskala } \\
\text { besar. Artinya, UMKM dapat mendorong terciptanya } \\
\text { persaingan yang lebih merata dan meningkatkan kondisi } \\
\text { persaingan pasar sehingga bisnis-bisnis pun terus berinovasi } \\
\text { untuk meningkatkan kepuasan konsumen mereka. }\end{array}$ \\
\hline $\begin{array}{l}\text { Mendukung } \\
\text { Perekonomian } \\
\text { Nasional \& Lokal }\end{array}$ & $\begin{array}{l}\text { Menurut Kementerian Koperasi dan UKM, bisnis UMKM } \\
\text { mampu menyumbang berkontribusi sebesar } 60 \% \text { terhadap } \\
\text { PDB. Dengan angka tersebut, UMKM memiliki peran } \\
\text { penting dalam mendukung jalannya roda perekonomian. } \\
\text { Selain itu, UKM juga mendorong perekonomian yang } \\
\text { merata. Berbeda dengan perusahaan besar yang biasanya } \\
\text { terletak di ibukota atau pusat kota saja, UKM lebih tersebar } \\
\text { di berbagai daerah. Hal ini memudahkan masyarakat di kota } \\
\text { kecil atau daerah untuk mengakses produk dan mendapatkan } \\
\text { penghidupan yang layak tanpa perlu menempuh jarak yang } \\
\text { jauh. }\end{array}$ \\
\hline $\begin{array}{l}\text { Menjawab } \\
\text { Kebutuhan } \\
\text { Masyarakat Lokal }\end{array}$ & $\begin{array}{l}\text { Bisnis besar biasanya memproduksi barang yang homogen. } \\
\text { Artinya, barang dijual di lokasi A dan di lokasi B merupakan } \\
\text { barang yang sama. Sebaliknya, UKM yang dikelola secara } \\
\text { mandiri akan lebih mencerminkan kebutuhan dan budaya } \\
\text { lokal di daerah bisnis tersebut. Dengan demikian, UKM bisa } \\
\text { lebih menjawab kebutuhan masyarakat lokal yang mungkin } \\
\text { belum bisa diberikan oleh bisnis berskala nasional. } \\
\text { Namun saat ini, UKM merupakan salah satu yang paling } \\
\text { terpukul selama pandemi Covid-19. PSBB, gangguan pada } \\
\text { rantai pemasokan, dan menurunnya permintaan konsumen } \\
\text { menciptakan tantangan besar yang belum pernah dialami para } \\
\text { pebisnis UKM sebelumnya. Dengan dimulai fase pemulihan } \\
\text { atau new normal, para pebisnis UKM diuji untuk beradaptasi } \\
\text { dengan situasi ini. }\end{array}$ \\
\hline
\end{tabular}




\section{BAB II BISNIS ONLINE}

\section{PEMASARAN KONVENSIONAL}

Secara umum pemasaran mengandung arti menyalurkan, menyebarluaskan atau meneruskan hasil produksi baik berupa barang/jasa dengan perhitungan tertentu baik ke distributor maupun ke konsumen dengan untuk mendapatkan laba. Inti dari pemasaran (marketing) adalah mengindentifikasi dan memenuhi kebutuhan manusia dan sosial. Salah satu definisi yang baik dan singkat dari pemasaran adalah memenuhi kebutuhan dengan cara yang menguntungkan.(Firmansyah, 2019) Definisi lainnya tentang pemasaran adalah suatu aktivitas yang bertujuan untuk mencapai sasaran perusahaan, dilakukan dengan cara mengantisipasi kebutuhan pelanggan atau klien serta mengarahkan aliran barang dan jasa yang memenuhi kebutuhan pelanggan atau klien dari produsen.(Cannon, Joseph P; Perreault, William D; McCarthy, 2008) Sehingga melalui proses manajerial tersebut dapat diidentifikasi kebutuhan pelanggan dan untuk memenuhi kebutuhan-kebutuhan tersebut dengan baik, maka produk yang tercipta akan menjual dirinya dengan otomatis.

Sebagaimana kita ketahui bahwa kegiatan pemasaran adalah berbeda dengan penjualan, transaksi ataupun perdagangan.(Supriatna, Yuda; Adiyanto, Yoga; Sunaryo, 2019) Yang mencirikan perbedaan tersebut adalah proses manajerial dari transaksi perdagangan tersebut. Dalam pemasaran dikenal sebuah aspek manajemen yang berfungsi sebagai tata kelola dari sebuah organisasi atau perusahaan, disebut dengan manajemen pemasaran. Manajemen pemasaran adalah kunci dari kelangsungan bisnis 
organisasi dengan menjalankan fungsinya sebagai proses pelaksanaan, dan penetapan seluruh aspek suatu produk pada saat awal sebelum diedarkan ke masyarakat.(Musfar, 2020)

Pemasaran yang kita kenal sebelum memasuki era digital dan masih eksis hingga kini adalah model pemasaran konvensional. Pemasaran Konvensional adalah salah satu jenis pemasaran yang dilakukan secara langsung (bukan online) dengan metode-metode konvensional (menggunakan kebiasaan umum yang lazim digunakan). Pembeli mendatangi langsung calon penjual secara bertatap muka dan begitu pula sebaliknya.(Markey, 2019) Cara transaksi ini masih diminati sampai sekarang oleh masyarakat.

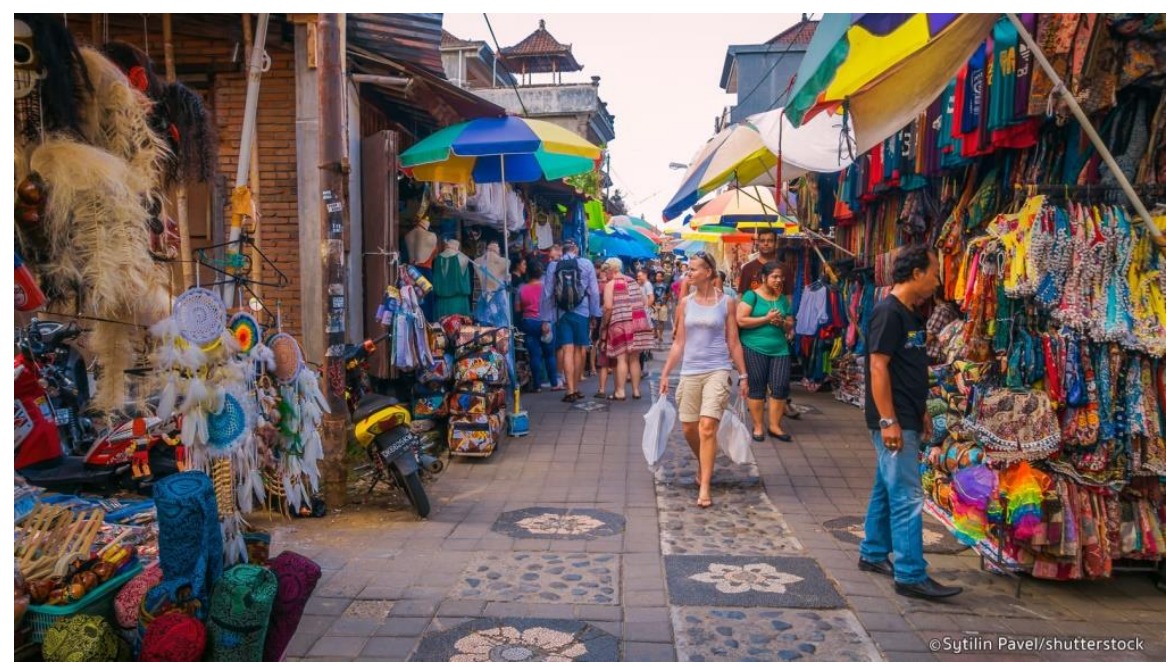

Gambar 1: Salah satu sudut pasar tradisional di daerah Ubud. (Hotels.com, n.d.)

Pada dasarnya, pemasaran tradisional adalah strategi promosi yang dilakukan sebelum adanya Internet. Hal Ini mencakup banyak taktik pemasaran seperti penjualan langsung, melalui TV, radio, surat, iklan cetak (misalnya, majalah, buku kupon, papan reklame dll), dan materi promosi tercetak seperti katalog atau brosur.(Semesta, 2020) 
Bahkan hingga saat ini dimana teknologi berkembang dengan sangat pesat, pemasaran secara tradisional ternyata masih memiliki banyak kelebihan:

1. Metode pemasaran secara tradisional mungkin satu-satunya alat untuk menjangkau kelompok konsumen tertentu Anda. Misalnya, jika Anda tertarik untuk menargetkan para CEO yang telah pensiun, sebagian besar demografis ini tidak memanfaatkan saluran media internet atau sosial media.

2. Penjualan secara "person to person" masih sangat dipertimbangkan oleh banyak strategi pemasaran tradisional. Pasti terdapat waktu dan tempat ketika melakukan penjualan secara tradisional karena hal ini memang cara paling efektif untuk memasarkan produk atau layanan. Misalnya, melalui orang-ke-orang, Anda bisa melakukan demonstrasi. Selanjutnya, banyak pelanggan dan klien lebih suka berbisnis dengan orang-orang yang berhubungan langsung dengan mereka.

3. Pemasaran tradisional menawarkan hal yang nyata. Ada sesuatu yang bisa dikatakan tentang memperlihatkan kepada para konsumen tentang hal yang nyata. Hal ini memudahkan untuk memberikan informas, seperti membagi-bagikan kartu nama atau memiliki sesuatu di acara-acara pribadi, seperti ceramah atau acara dagang.

Beberapa kekurangan pemasaran tradisional, seperti:

1. Biaya yang lebih mahal: Membayar iklah di TV, radio, atau media cetak bisa sangat mahal bagi banyak pemilik bisnis rumahan.

2. Sulit Melacak untuk Hasil: Pemasaran tradisional sangat mirip melempar benda ke dinding dan berharap mereka tetap bertahan. Sangat sulit untuk melacak hasil kuantitatif yang nyata.

3. Biasanya Membutuhkan Bantuan dari pihak Luar: Materi pencetakan, media pembelian dan pembuatan iklan di media, semuanya memerlukan bantuan dari pihak luar, seperti desainer grafis atau penulis skrip, yang menambah biaya.

4. Hanya satu arah: Pemasaran tradisional biasanya dipaksakan pada konsumen, dan hal ini sering mengganggu mereka. Banyak orang tidak suka kotak surat mereka sarat dengan email spam. 


\section{MODEL PENJUALAN DIGITAL}

Pada era sekarang ini, bisnis online sudah tidak asing lagi bagi para pelaku dagang. Banyak orang melakukan pemasaran produknya dengan metode penjualan digital. Awal penggunaan teknologi dalam bidang pemasaran adalah untuk beriklan. Mengapa orang-orang memilih untuk beriklan secara digital adalah karena beberapa alasan berikut:(Suyanto, 2003)

1. Iklan dapat di-update setiap waktu dengan biaya minimal, karena hal tersebut iklan-iklan di internet selalu bias tampil baru.

2. Iklan dapat menjangkau pembeli potensial dalam jumlah yang sangat besar dalam hitungan global.

3. Iklan online kadang lebih murah dibandingkan iklan televisi, koran atau radio. Media beriklan yang disebutkan belakangan itu menjadi lebih mahal karena ditentukan oleh ruang yang akan dipakai, berapa hari (waktunya) iklan tersebut dimuat, serta pada berapa stasiun televise dan koran lokal atau nasional iklan dipasang.

4. Iklan pada e-commerce dapat secara efisien menggunakan konvergensi teks, audio, grafik dan animasi.

5. Manfaat internet sendiri sedang berkembang pesatnya.

6. Iklan e-commerce dapat dibuat interaktif dan dibidikkan ke kelompok-kelompok tertentu dan/atau perorangan.

Seiring dengan perkembangan teknologi serta berkembangnya kemampuan manusia memahami teknologi, tidak hanya proses dalam beriklan yang dilakukan didalam dunia maya bahkan bertransaksi juga dilakukan di dalam dunia digital. Namun menjalankan bisnis secara online /digital tidaklah mudah, dibutuhkan suatu pola yang sistematis agar dapat membantu para pelaku usaha memudahkan bisnisnya. Menurut Des Chandra Kusuma, beberapa hal yang harus diperhatikan sebagai gambaran alur kerja bisnis online adalah :(Kusuma, 2018)

A. Marketing Research (termasuk didalamnya segementasi pasar.

B. Konsep Toko Online

C. Pembuatan Desain Toko Online

D. Pembuatan Sistem Toko Online

E. Perawatan Situs Web Toko Online 
F. Pencarian Produk

G. Survei Vendor

H. Persiapan Vendor, Hosting, dan Internet

I. Modal (Stok/Lokasi)

J. Aktivitas dan Biaya Operasional

K. Distribusi Pengiriman

L. Excellent Service

M. Customer's Trust

N. Membangun Loyalitas Pembeli

O. Perbankan dan Perizinan

A. Marketing Research (termasuk didalamnya segementasi pasar)

" Still Facebook is the most widely engaged social media site with well over a billion active users and so its potential for structuring human communication according to its own logics of platform sovereignty remains profound. ”(Bratton, 2015)

Strategi Pemasaran menurut penelitian yang dakukan oleh Endang Purwanti dapat dilakukan dengan 4 cara yaitu, Penentuan harga, Penentuan pasar, Promosi yang dijalankan, dan Kualitas produk(Purwanti, 2012)

1. Penentuan Harga : Pelaku usaha harus menentukan terlebih dahulu harga dari barang/jasa yang dijual dengan mempertimbangkan aspek-aspek penentu harga baik yang bersifat internal (biaya produksi) maupun eksternal (harga sejenis dari kompetitor)

2. Penentuan Pasar : Segmentasi diperlukan untuk memperjelas sasaran pemasaran. Misalnya ketika menjual produk panci tidak mungkin anda memasang promo yang followernya kebanyakan remaja usia sekolah.

3. Promosi : Terkait dengan pasar, promosi harus dilakukan dengan tepat dengan berbagai platform online yng ada, baik sosial media, marketplace maupun e-commerce 
4. Kualitas Produk : Pelanggan akan selalu mengharapkan kualitas terbaik dari produk yang mereka beli. Di dalam bisnis online, penunjang dari tampilan produk yang baik adalah kualitas serta cara pengambilan foto yang baik.

Selain strategi pemasaran, dibutuhkan marketing research sebelum memulai sebuah bisnis online. Seperti data berikut yang diperoleh di website Wearesocial, dapat memberi pelaku usaha sebuah gambaran mengenai jumlah sosial media terfavorit. Sehingga dapat dijadikan salah satu acuan untuk membuat pola pemasaran yang paling mendekati.

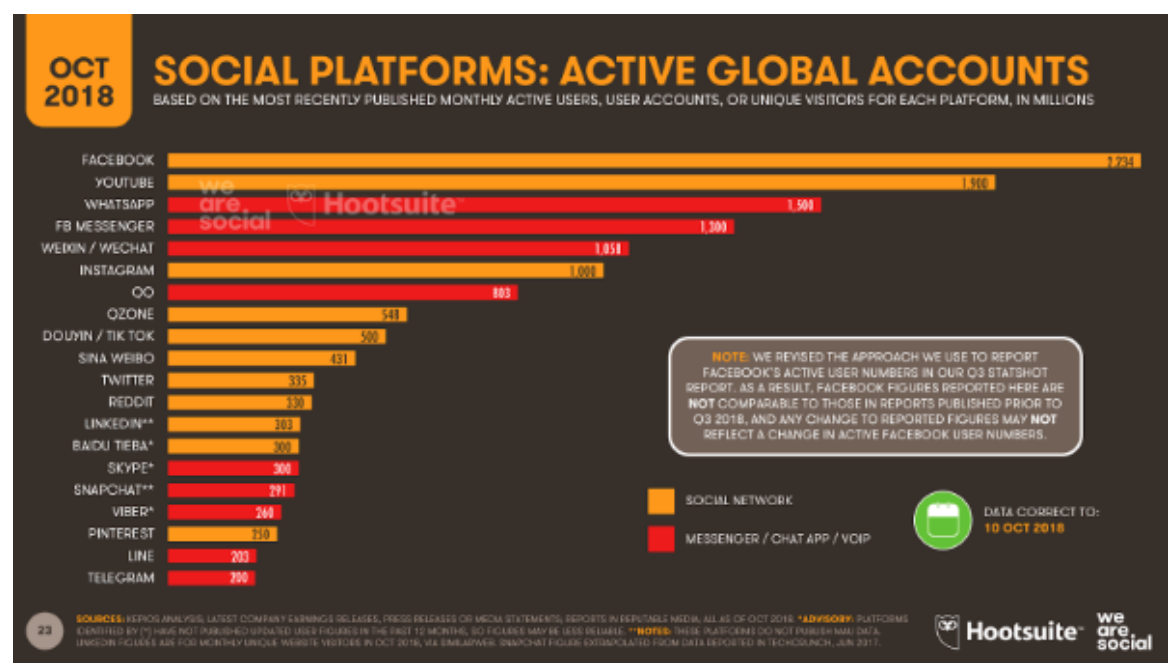

Gambar 2: Statistik pengguna aktif media sosial pada kuartal 4 tahun 2018.(Wearesocial, 2018)

\section{B. $\quad$ Konsep Toko Online}

Konsep toko adalah hal yang menjadi dasar atau patokan dalam pengembangan bisnis kedepannya. Konsep adalah karakter serta nyawa dari sebuah toko online. Konsep dapat ditentukan apabila setelah melakukan marketing research calon pelaku bisnis online telah menentukan segmen bisnis yang akan dijalankan. Selain itu, prinsip dari diferensiasi yang harus dilakukan adalah memilih nama untuk sebuah toko online harus memperhatikan Bab VI UU ITE terkait nama domain, hak kekayaan intelektual dan perlindungan pribadi. 


\section{Pembuatan Desain, Sistem dan Perawatan Situs Website Toko Online}

Desain toko online seharusnya tidak melenceng jauh dari konsep awal pembuatan toko online. Idealnya desain yang dibuat dapat menjelaskan konsep dari sebuah toko. Maka dari itu merancang sebuah desain toko bukanlah hal yang mudah, karena akan banyak pertimbangan yang muncul baik dari segi layout maupun pemilihan warna. Namun tidak sedikit toko online yang terkesan "ngawur" dalam merancang dan memilih desain. Sehingga banyak konsep dari toko online yang kurang menjiwai desain toko tersebut.

\section{Pencarian Produk}

Google adalah mesin pencari terbesar di dunia yang paling berpengaruh saat ini. Berada pada ratting atas Google adalah salah satu indikasi sebuah bisnis online yang digemari oleh banyak orang. Ketika pelanggan mengetikkan aneka ragam produk untuk mencarinya di internet, sebagian besar dari pengguna akan mengakses Google untuk mencari produk dan toko online yang sesuai dengan keinginan mereka.(RM, 2017) Dan untuk meningkatkan ratting sebuah bisnis di Google, seorang pelaku bisnis online dapat mempelajari lebih lanjut mengenai strategi Search Engine Optimization (SEO).

\section{E. Survei Vendor}

Di dalam bisnis konvensional istilah untuk vendor merujuk pada (satu atau beberapa) pihak ketiga yang memiliki keterkaitan dengan usaha atau bisnis yang sedang dijalankan. Sebagai contoh, sebuah usaha jahit biasanya memiliki vendor material yaitu, toko kain dan toko alat jahit. Survei perlu dilakukan untuk menentukan pihak manakah yang paling baik sesuai dengan kebutuhan usaha tersebut. Selain itu survei vendor sekaligus memberikan informasi ataupun pilihan tentang vendor-vendor yang dimasukkan ke dalam daftar vendor utama dan vendor cadangan.

\section{F. Persiapan Vendor, Hosting, dan Internet}

Vendor, hosting dan internet merupakan modal dasar dalam menjalankan bisnis online. Dan sekaligus menjadi hal yang patut pula mendapatkan perhatian lebih karena ketiga hal tersebut berada diluar 
kendali pelaku usaha. Pelaku usaha dituntut untuk berpikir kreatif dan senantiasa high motivated ketika terjadi hal-hal diluar dugaan atau harapan.

\section{G. Modal (Stok/Lokasi)}

Modal dalam menjalankan bisnis online sebenarnya jauh lebih murah daripada toko konvensional. Karena toko yang dibuka bersifat virtual jadi tidak diperlukan biaya yang besar seperti interior misalnya. Perbandingan biaya sewa toko online dibandingkan dengan sewa toko virtual sangatlah signifikan.

\section{H. Aktivitas dan Biaya Operasional}

Kegiatan operasional adalah kegiatan yang menghasilkan produk dari suatu usaha, baik berupa barang maupun jasa. Diperlukan kemampuan pengelolaan yang baik dalam aspek operasional agar tujuan dari organisasi ataupun usaha dapat berjalan dengan ideal atau sesuai dengan ekspektasi pendirian usaha.

\section{Distribusi Pengiriman}

Pengiriman barang pada bisnis online merupakan salah satu tahapan yang sangat vital. Pelaku usaha harus memastikan barang yang diterima oleh konsumen dalam kondisi yang baik, serta tiba tepat pada waktunya. Hal tersebut mengharuskan pelaku usaha bisnis online untuk memilih kurir yang memiliki kredibilitas yang baik. Dalam hal ini rekomendasi dari pelaku bisnis online lainnya juga dibutuhkan sebagai pembanding.

\section{J. Excellent Service}

Dibutuhkan suatu pelayanan yang prima atau pelayanan terbaik untuk memenuhi harapan dan kebutuhan dari pelanggan. Dengan kata lain, pelayanan prima merupakan suatu pelayanan yang memenuhi standar kualitas yang sudah ditentukan.(Rangkuti, 2017)

\section{K. Customer's Trust}

Itikad baik adalah dasar utama dari sebuah kepercayaan. Dalam menjalankan bisnis online. Pelaksanaan transaksi bisnis online antara penjual dan pembeli tidak saling bertatap muka. Sehingga akan sangat 
wajar apabila kedua belah pihak saling mencurigai. Misalnya kekhawatiran penjual terhadap pembeli tidak melakukan transfer sesuai dengan tata cara perbankan yang legal, atau pun kekhawatiran pembeli apabila penjual tidak benar-benar mengirimkan barang yang dipesan. Hal itulah yang mendasari transaksi bisnis secara online harus dilakukan dengan itikad baik.

\section{Membangun Loyalitas Pembeli}

Telah banyak sekali platform penilaian pelanggan dalam transaksi online. Terkait pula dengan customer's trust, platform tersebut biasanya menyediakan penjelasan mengenai review kepuasan pembeli. Biasanya ketika pembeli merasa puas, maka pembeli tersebut akan menjadi pelanggan loyal dari sebuah usaha. Tidak hanya itu bentuk lain dari loyalitas pembeli tersebut adalah rekomendasi atau review. Contoh platform kepuasan pelanggan salah satunya adalah Trip Advisor. Trip Advisor dapat dijadikan sebagai media alternatif untuk membangun loyalitas pelanggan.

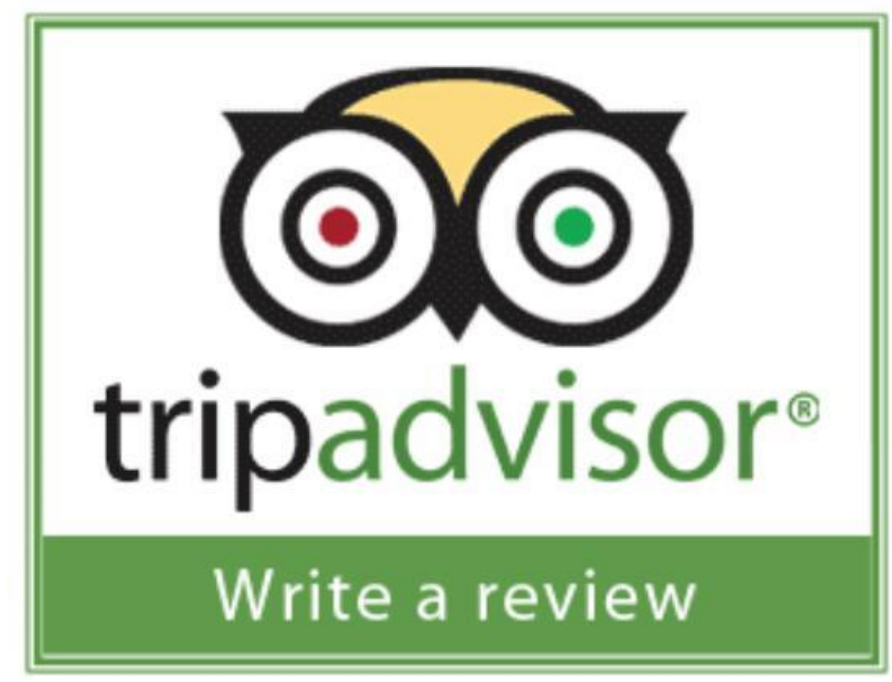

Gambar 3: Tripadvisor, platform loyalitas pelanggan. (Tripadvisor, n.d.) 


\section{Perbankan dan Perizinan}

Pemerintah dalam konteks fasilitator sangat mendukung para pelaku usaha di Indonesia utamanya dalam hal perizinan dan perbankan. Melalui pembaharuan serta evaluasi kebijakan, pemerintah mempermudah tatacara berusaha para pelaku usaha. Selain hal-hal terkait kebijakan, pemerintah bersinergi bersama perbankan mengeluarkan kebijakan terkait pinjaman modal dengan bunga yang cukup rendah melalui program KUR (Kredit Usaha Rakyat). Pemerintah menyalurkan dana KUR kepada para pelaku usaha mikro, pada tahun 2016 dana yang disalurkan yaitu mencapai Rp100 triliun. Penyaluran KUR dilakukan melalui lembaga keuangan dan bank yang ada di Indonesia, bank yang paling banyak menyalurkan KUR adalah bank BRI.

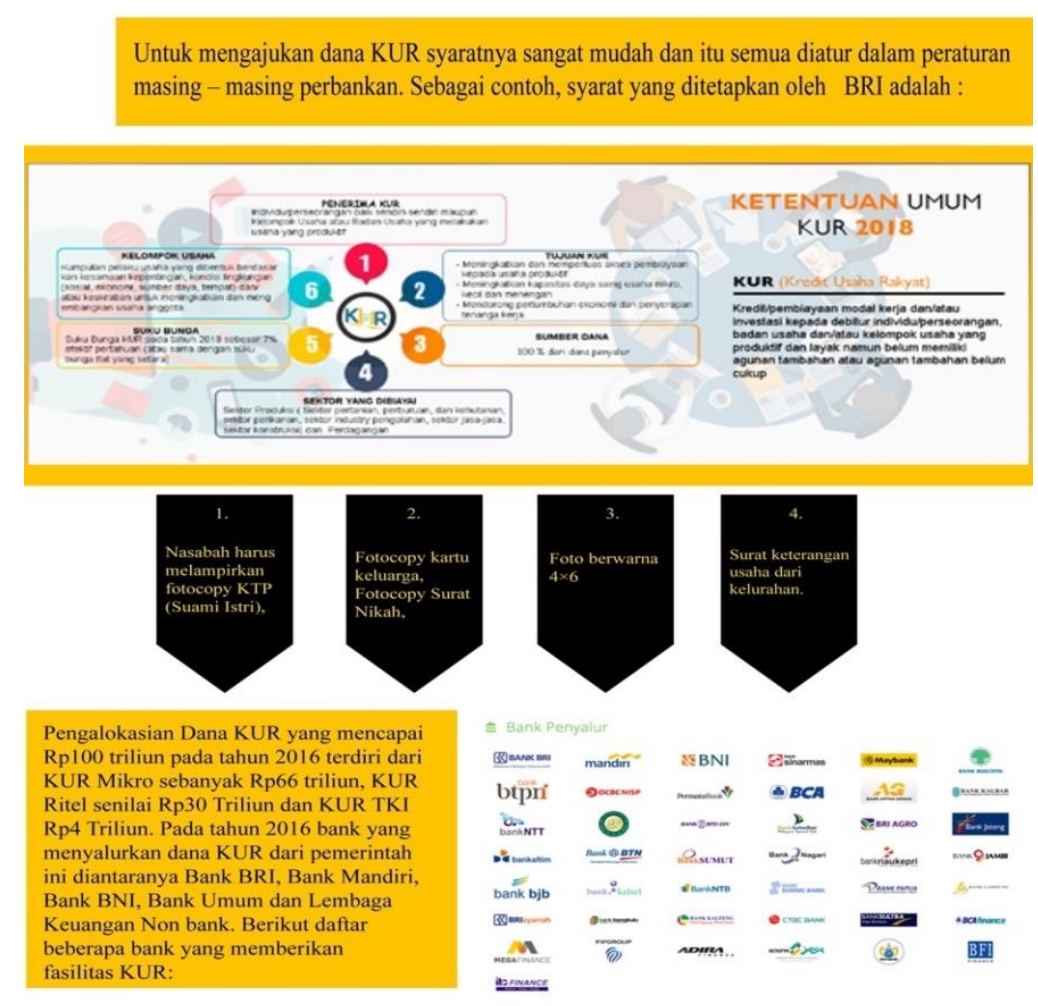

Gambar 5: Ilustrasi KUR (diolah sendiri) 


\section{BAB III \\ REGULASI TERKAIT UMKM DAN E-COMMERCE}

Pemanfaatan Teknologi Informasi di berbagai bidang sesuai dengan yang diatur di dalam Peraturan Perundang-undangan, bahwa pemanfaatan Teknologi Informasi juga dapat dipergunakan untuk mengembangkan perdagangan dan perekonomian nasional dalam rangka meningkatkan kesejahteraan masyarakat.(UU Informasi Dan Transaksi Elektronik, 2016) Atas dasar tersebut regulasi nasional terkait dengan transaksi elektronik idealnya dan diharapkan dapat memberikan kontribusi yang besar dalam rangka mendongkrak perekonomian dalam ranah UMKM. Untuk itu diperlukan pemahaman atas berbagai regulasi terkait pengembangan UMKM yang berlaku di Indonesia.

Selain mengetahui mengenai UU ITE dalam rangka UMKM go online, perlu diketahui beberapa tipe atau jenis regulasi terkait dengan perdagangan atau usaha. Berlaku asas Fiksi Hukum, yang beranggapan bahwa ketika suatu peraturan perundang-undangan telah diundangkan maka pada saat itu setiap orang dianggap tahu (presumption iures de iure) dan ketentuan tersebut berlaku mengikat sehingga ketidaktahuan seseorang akan hukum tidak dapat membebaskan/memaafkannya dari tuntutan hukum (ignorantia jurist non excusat). Keberadaan asas fiksi hukum, telah dinormakan di dalam penjelasan Pasal 81 ketentuan Undang-Undang Nomor 12 Tahun 2011 tentang Peraturan Perundang-undangan yakni "Dengan diundangkannya Peraturan Perundang-undangan dalam lembaran resmi sebagaimana dimaksud dalam ketentuan ini, setiap orang dianggap 
telah mengetahuinya". Jadi para pelaku usaha, paling tidak telah mengetahui kebijakan atau peraturan yang manakah yang berlaku dalam pelaksanaan kegiatan usahanya.(Agung, 2017)

Secara umum ketentuan atau regulasi terkait usaha dapat dilihat pada gambar berikut:

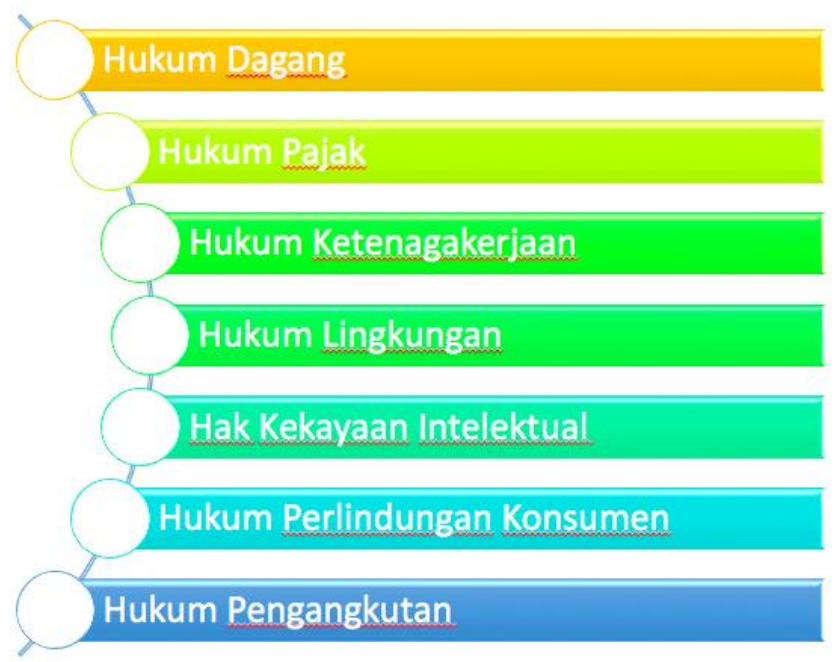

Gambar 6: Ilustrasi Regulasi Terkait Perdagangan (diolah sendiri)

\section{HUKUM BISNIS}

Apa itu Hukum Bisnis???

Hukum mengandung pengertian keseluruhan kaidah serta semua asas yang mengatur pergaulan hidup dalam masyarakat dan bertujuan untuk memelihara ketertiban serta meliputi berbagai lembaga dan proses guna mewujudkan berlakunya kaidah sebagai suatu kenyataan dalam masyarakat.(Jonaedi Efendi, 2016) Menurut salah satu pakar hukum kenamaan asal Belanda, E. Utrecht, hukum adalah himpunan petunjuk hidup yang mengatur tata tertib dalam suatu masyarakat dan seharusnya ditaati oleh anggota masyarakat yang bersangkutan, oleh karenanya pelanggaran terhadap petunjuk hidup itu dapat menimbulkan tindakan dari pemerintah masyarakat itu. 
Hukum bisnis merupakan semua ketentuan hukum yang bersifat tertulis maupun lisan, yang mengatur berbagai hak dan kewajiban akibat dari adanya suatu perjanjian dan perikatan yang terjadi dalam aktivitas bisnis.(Tambunan, Toman Sony; Tambunan, 2019) Hukum bisnis pada implementasinya di lapangan kegiatan perekonomian menggunakan metode sesuai dengan alur perjalanan arah perkembangan di berbagai sector usaha dan industri.(Laila, 2018)

\section{Sejarah Hukum Dagang di Indonesia}

Interaksi dengan hukum dagang pada dasarnya baru mulai dikenal ketika manusia mengenal suatu bentuk perilaku yang disebut dengan barter. Dikemukakan demikian karena sesederhana apapun yang dilakukan, barter tersebut sesungguhnya merupakan suatu sistem yang mengintrodusikan dan mendasarkan kinerjanya pada syarat-syarat yang disepakati dan semua ini merupakan representasi dari aturanaturan.(Sumadi, 2019)

Perkembangan hukum dagang di dunia telah berlangsung pada tahun 1000 hingga 1500 pada abad pertengahan di Eropa. Kala itu telah lahir kota-kota yang berfungsi sebagai pusat perdagangan, seperti Genoa, Venesia, Marseille, Florence hingga Barcelona. Meski telah diberlakukan Hukum Romawi (Corpus Iulis Civilis), namun berbagai masalah terkait perdagangan belum bisa diselesaikan. Maka dari itu dibentuklah Hukum Pedagang (Koopmansrecht). Saat itu hukum dagang masih bersifat kedaerahan. Kodifikasi hukum dagang pertama dibentuk di Prancis dengan nama Ordonance de Commerce pada masa pemerintahan Raja Louis XIV pada 1673. Dalam hukum itu terdapat segala hal berkaitan dengan dunia perdagangan, mulai dari pedagang, bank, badan usaha, surat berharga hingga pernyataan pailit. Pada 1681 lahirlah kodifikasi hukum dagang kedua dengan nama Ordonance de la Marine. Dalam kodifikasi ini termuat segala hal berkaitan dengan dagang dan kelautan, misalnya tentang perdagangan di laut.(Wikipedia, 2020)

Kedua hukum itu kemudian menjadi acuan dari lahirnya $\underline{\text { Code de }}$ Commerce, hukum dagang baru yang mulai berlaku pada 1807 di Prancis. Code de Commerce membahas tentang berbagai peraturan hukum yang timbul dalam bidang perdagangan sejak abad pertengahan. Code de 
Commerce kemudian menjadi cikal bakal hukum dagang di Belanda dan Indonesia. Sebagai negara bekas jajahan Prancis, Belanda memberlakukan Wetboek van Koophandel yang diadaptasi dari Code de Commerce. Meski telah dipublikasikan sejak 1847, penerapan Wetboek van Koophandel baru berlangsung sejak 1 Mei 1848. Lalu Belanda menjajah Indonesia dan turut mempengaruhi perkembangan hukum dagang di Indonesia. Akhirnya lahirlah Kitab Undang-undang Hukum Dagang (KUHD) yang diadaptasi dari Wetboek van Kopphandel yang kemudian menjadi salah satu sumber dari hukum dagang Indonesia.

\section{Pengertian Hukum Dagang}

Hukum dagang ialah hukum yang mengatur tingkah laku manusia yang turut melakukan perdagangan untuk memperoleh keuntungan atau hukum yang mengatur hubungan hukum antara manusia dan badan-badan hukum satu sama lainnya dalam lapangan perdagangan.(Suwardi, 2015) Hukum dagang adalah ilmu yang mengatur hubungan antara suatu pihak dengan pihak lain yang berkaitan dengan urusan-urusan dagang. ${ }^{[1]}$ Definisi lain menyatakan bahwa hukum dagang merupakan serangkaian norma yang timbul khusus dalam dunia usaha atau kegiatan perusahaan. (Wikipedia, 2020) Hukum dagang masuk dalam kategori hukum perdata, tepatnya hukum perikatan. Alasannya karena hukum dagang berkaitan dengan tindakan manusia dalam urusan dagang. Oleh karena itu hukum dagang tidak masuk dalam hukum kebendaan. Kemudian hukum dagang juga berkaitan dengan hak dan kewajiban antar pihak yang bersangkutan dalam urusan dagang. Hukum perikatan mengatur hal ini. Itulah sebabnya hukum dagang dikategorikan ke dalam hukum perikatan. Hukum perikatan adalah hukum yang secara spesifik mengatur perikatan-perikatan dalam urusan dagang.

\section{Sumber dan Dasar Hukum Dagang}

Hukum dagang di Indonesia tidak tercipta begitu saja, melainkan berdasarkan pada sumber. Terdapat tiga jenis sumber yang menjadi rujukan dari hukum dagang, yakni hukum tertulis yang sudah dikodifikasikan, hukum tertulis yang belum dikodifikasikan dan hukum kebiasaan. Pada hukum tertulis yang sudah dikodifikasikan, hal yang 
menjadi acuan adalah KUHD yang mempunyai 2 kitab dan 23 bab. Dalam KUHD dibahas tentang dagang umumnya sebanyak 10 bab serta hak-hak dan kewajiban sebanyak 13 bab. Selain KUHD, sumber lainnya adalah Kitab Undang-undang Hukum Perdata (KUHPerdata) atau juga dikenal dengan istilah Burgerlijk Wetboek $(\mathrm{BW})$. Salah satu bab pada BW membahas tentang perikatan.

Pada hukum tertulis yang belum dikodifikasikan, ada 4 Undangundang yang menjadi acuan. Keempat UU itu adalah Undang-undang Nomor 40 tahun 2007 tentang Perseroan Terbatas, Undang-undang Nomor 8 tahun 1995 tentang Pasar Modal, Undang-undang Nomor 32 tahun 1997 tentang Perdagangan Berjangka Komoditi dan Undang-undang Nompr 8 tahun 1997 tentang dokumen perusahaan. Adapun pada hukum kebiasaan, hal yang menjadi sumber adalah Pasal 1339 KUH Perdata dan Pasal 1347 KUH Perdata.

Pendukung hak dan kewajiban hukum yang dimiliki oleh manusia sejak lahir hingga meninggal dunia dan juga dimiliki oleh pribadi hukum yang secara sengaja diciptakan oleh hukum sebagai subjek hukum. Definisi lain menjelaskan bahwa subjek hukum adalah setiap orang yang mempunyai hak dan kewajiban sehingga memiliki wewenang hukum (rechtbevoegheid). Dalam hukum dagang, hal yang menjadi subjek hukum adalah badan usaha. Istilah lain dari badan usaha adalah perusahaan, baik perseorangan ataupun telah memiliki badan hukum. Ada 8 jenis badan usaha, yakni:

1. Perusahaan Dagang/Usaha Dagang (PD/UD)

2. Firma (fa)

3. Commanditaire Vennotschap (CV)

4. Perseroan Terbatas

5. Koperasi

6. Perseroan

7. Perum

8. Holding Company/Grup/Concern

\section{Hubungan Hukum Dagang dan Hukum Perdata}

Hukum dagang merupakan hukum perdata khusus yang dirancang atau diciptakan bagi kaum pedagang.(Laila, 2018) Pada mulanya kaidah 
hukum yang dikenal sebagai hukum dagang saat ini mulai muncul di kalangan kaum pedagang sekitar abad ke-17. Kaidah-kaidah hukum tersebut sebenarnya merupakan kebiasaan diantara mereka yang muncul dalam pergaulan di bidang perdagangan. Ada beberapa hal yang diatur dalam KUH Perdata (Kitdab Undang-Undang Hukum Perdata) diatur juga didalam KUHD (Kitab Undang-Undang Hukum Dagang).(Jonaedi Efendi, 2016)

Hukum dagang sebagai bagian dari hukum perdata, secara khusus berada pada hukum perikatan, yaitu tentang perikatan yang timbul sehubungan dengan menjalankan kegiatan dagang atau perdagangan. Oleh karena itu sifat dasar dari hukum dagang adalah privat (perdata). Degan demikian, perdagangan dilihat dari aspek hukum perdata khususnya aspek hukum perikatan sama seperti KUH Dagang. Hal ini merupakan warisan dari hukum Belanda yang menjadi asal dari kedua undang-undang diatas, yang tidak terlepas juga dari hukum Perancis yaitu Code Civil dan Code du Commerce yang disebut bersifat individualis-liberalis.(Sidabalok, 2020)

\section{E-Commerce}

Keunggulan E-commerce adalah kemampuan bertransaksi kapan pun, diakses dari manapun, adanya pemotongan jalur distribusi, dapat langsung melakukan pembelian, dan adanya penghematan biaya.(Sakti, 2014) Hal ini sejalan dengan tujuan dari pengembangan teknologi yaitu mempermudah umat manusia di berbagai aktivitas.

24 Ni Putu Suci Meinarni ... [et al.] 


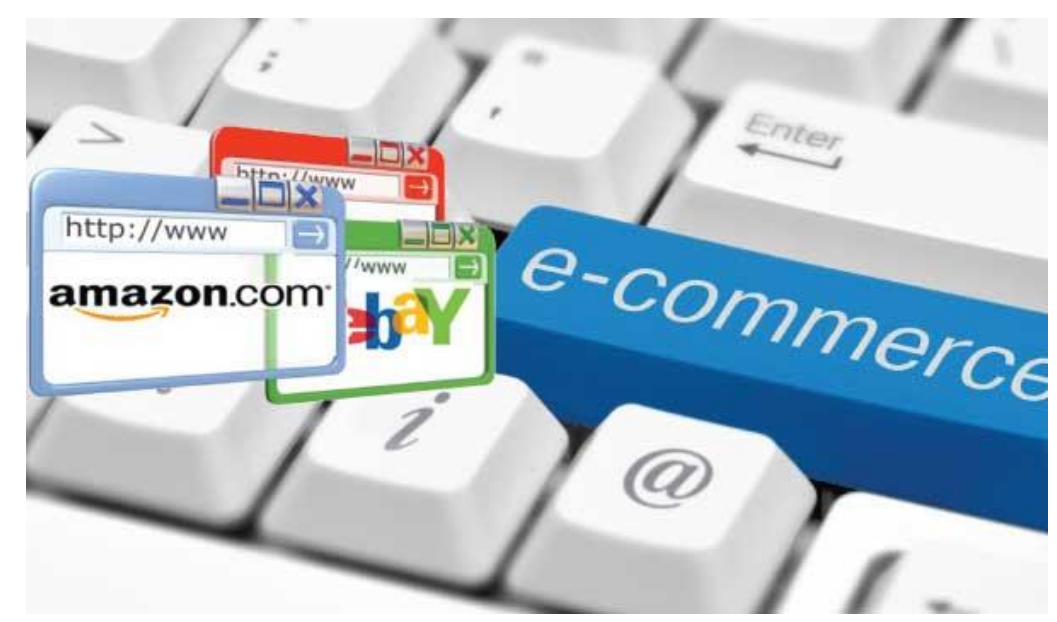

Gambar 7: Ilustrasi E-Commerce (Makalah.id, 2017)

Penerapan electronic commerce bermula di awal tahun 1970-an, dengan adanya inovasi semacam electronic fund transfer (EFT).(Suyanto, 2003) Sedangkan di Indonesia, e-commerce bermula pada tahun 1994 dengan hadirnya IndoNet sebagai Internet Service Provider (ISP) komersil pertama, dimana kehadirannya menjadi pembuka kesempatan dan peluang pemanfaatan teknologi telekomunikasi dan informasi yang sebesarbesarnya dalam segala bidang, termasuk perdagangan.(Romindo; Muttaqin; Saputra, Didin Hadi; Purba, Deddy Wahyudin; Iswahyudi, M.; Banjarnahor, Astri Rumondang; Kusuma, Aditya Halim Perdana; Faried, Effendi; Sulaiman, Oris Kristianto; Simarmata, 2019) E-commerce sudah menjadi bagian dalam kehidupan sehari-hari pada jaman dimana perkembangan teknologi informasi dan telekomunikasi sangat pesat.(Sarwono, Jonathan; Prihartono, 2012)

Pada transaksi e-commerce di Indonesia dikenal istilah "sistem elektronik" yang diatur dalam Pasal 1 angka 5 yaitu:

"Sistem Elektronik adalah serangkaian perangkat dan prosedur elektronik yang berfungsi mempersiapkan, mengumpulkan, mengolah, menganalisis, menyimpan, menampilkan, mengumumkan, mengirimkan, dan/atau menyebarkan Informasi Elektronik." 
Dari uraian tersebut diatas, maka saat ini pengertian perjanjian/kontrak elektronik telah mempunyai pengertian yang pasti serta memiliki landasan hukum kuat apabila ingin dilakukan.

Kemudian selain itu, di dalam Pasal 18 UU ITE telah diuraikan mengenai tata cara penggunaan perjanjian/kontrak elektronik tersebut, yaitu:

1. Transaksi Elektronik yang dituangkan ke dalam Kontrak Elektronik mengikat para pihak;

2. Para pihak memiliki kewenangan untuk memilih hukum yang berlaku bagi Transaksi Elektronik internasional yang dibuatnya;

3. Jika para pihak tidak melakukan pilihan hukum dalam Transaksi Elektronik internasional, hukum yang berlaku didasarkan pada asas Hukum Perdata Internasional;

4. Para pihak memiliki kewenangan untuk menetapkan forum pengadilan, arbitrase, atau lembaga penyelesaian sengketa alternatif lainnya yang berwenang menangani sengketa yang mungkin timbul dari Transaksi Elektronik internasional yang dibuatnya;

5. Jika para pihak tidak melakukan pilihan forum sebagaimana dimaksud pada ayat (4), penetapan kewenangan pengadilan, arbitrase, atau lembaga penyelesaian sengketa alternatif lainnya yang berwenang menangani sengketa yang mungkin timbul dari transaksi tersebut, didasarkan pada asas Hukum Perdata Internasional.

Dari uraian Pasal 18 UU ITE tersebut disimpulkan bahwa:

1. Perjanjian/kontrak elektronik dapat digunakan apabila melakukan perbuatan hukum dengan menggunakan transaksi elektronik. Adapun yang dimaksud transaksi elektronik menurut UU ITE adalah perbuatan hukum yang dilakukan dengan menggunakan komputer, jaringan komputer, dan/atau media elektronik lainnya;

2. Apabila terjadi sengketa hukum akibat dari kontrak elektronik yang dibuat, maka para pihak mempunyai hak untuk memilih pilihan hukum mana yang akan diselesaikan, termasuk memilih untuk diselesaikan melalui forum pengadilan yang ada di negara Indonesia atau diluar yang memakai ketentuan-ketentuan hukum Internasional sepanjang itu diperjanjian di dalam perjanjian/kontrak elektronik; 
3. Apabila para pihak tidak memilih pilihan hukum mana untuk menyelesaikan sengketa yang timbul akibat perjanjian/kontrak elektronik yang dibuatnya, maka yang berlaku adalah hukum perdata Internasional.(Doktorhukum, 2019)

Untuk mengoptimalkan pemanfaatan potensi ekonomi digital atau yang berbasis elektronik, pemerintah perlu mendorong percepatan dan pengembangan sistem perdagangan nasional berbasis elektronik $e$ commerce dan usaha pemula start-up terutama yang bergerak dalam bidang teknologi. Selain itu untuk pengembangan usaha \& percepatan logistik, pemerintah perlu menetapkan peta jalan sistem perdagangan nasional berbasis elektronik roadmap e-commerce yang terintegrasi. Peta jalan ini berfungsi sebagai acuan bagi pemerintah pusat dan daerah untuk menetapkan kebijakan sektoral dan rencana tindak dalam rangka percepatan pelaksanaan e-commerce dan menjalankan kegiatan ecommerce para pemangku kepentingan.(Indonesiabaik.id, 2017) Program ini ditetapkan dalam Peraturan Presiden Nomor 74 tahun 2017 tentang Peta Jalan Sistem Perdagangan Nasional Berbasis Elektronik (Road Map E-Commerce) tahun 2017-2019.

\section{PROGRAM}

PETA JALAN E-COMMERCE 2017-2019

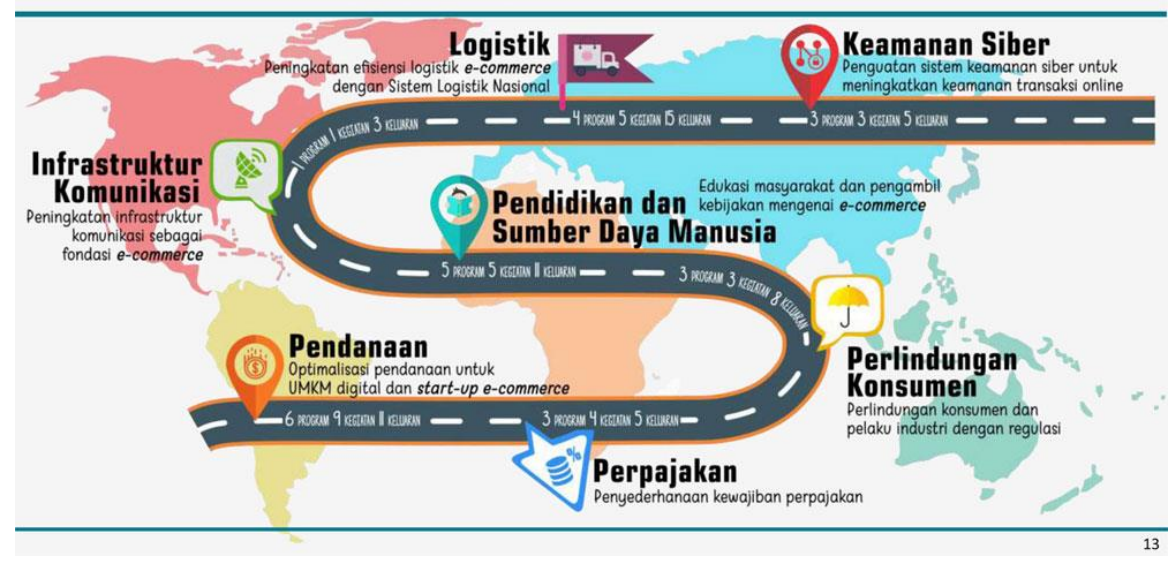

Gambar 8: Peta Jalan Perdagangan Nasional Indonesia. (Bocweb.id, 2017) 


\section{TATA CARA PENDAFTARAN USAHA}

Untuk mendirikan usaha, seorang pelaku usaha hendaknya menentukan terlebih dahulu bentuk usaha yang akan dibangun. Bentuk usaha tersebut menyesuaikan dengan jenis usaha yang akan dibuat. Urgensi pendukung digitalisasi, melalui kebijakan pemerintah mengenai izin usaha terintegrasi,(Peraturan Pemerintah Republik Indonesia Nomor 24 Tahun 2018 Tentang Pelayanan Perizinan Berusaha Terintegrasi Secara Elektronik, 2018) Sebenarnya masyarakat sudah tidak perlu khawatir lagi dalam berusaha. Apabila mereka ingin memulai usahanya, kini telah disediakan platform online oleh pemerintah terkait dengan izin pendirian usaha.

Persyaratan umum yang harus dipenuhi oleh pelaku usaha antara lain:

1. KTP

2. NPWP

3. Surat Keterangan Domisili Usaha

Persyaratan tersebut merupakan persyaratan minimal yang harus dimiliki untuk memulai usaha, paling tidak untuk memulai bisnis UMKM. Selanjutnya akan dijelaskan mengenai surat-surat pelengkap lainnya pada pendirian usaha. Berbagai jenis surat dokumen kelengkapan di dalam usaha yang akan jalankan, hal ini perlu diketahui agar usaha yang dikelola nantinya tidak mendapatkan hambatan atau kendala di mata hukum yang diberlakukan.

Untuk dokumen pelengkap usaha ini banyak sekali yang nantinya perlu dipenuhi saat mendirikan sebuah badan usaha entah itu nanti berupa firma, CV, ataupun perseroan terbatas (PT). Dan dokumen-dokumen ini nanti dikeluarkan oleh instansi terkait, untuk mempersingkat pembahasan dibawah ini telah kami rangkumkan 12 macam jenis surat kelengkapan di dalam mendirikan suatu badan usaha. Berikut adalah jenis-jenis dokumen tersebut:

\section{Surat Keterangan Domisili Usaha (SKDU)}

Surat keterangan domisili usaha ini adalah salah satu dari sekian banyaknya dokumen yang harus dimiliki oleh sebuah badan usaha, sebab nantinya surat ini akan diperlukan untuk memproses dokumendokumen lain seperti dokumen SIUP, NPWP serta TDP serta surat 
pendukung dalam pendirian usaha anda. Surat keterangan domisili ini nantinya diterbitkan oleh kelurahan atau kecamatan dimana lokasi usaha anda didirikan. Bila seluruh persyaratan yang diperlukan untuk mengurus SKDU sudah komplit biasanya surat keterangan domisili ini bisa jadi dalam waktu satu hari. Untuk keterangan mengenai apa saja yang diperlukan untuk membuat SKDU silahkan anda bertanya di masing-masing kelurahan atau kecamatan dimana anda akan mendirikan usaha.(Yogos-Shelter, 2014)

\section{Nomor Pokok Wajib Pajak (NPWP)}

Surat kelengkapan dalam mendirikan usaha selanjutnya adalah dokumen NPWP yang merupakan kependekan dari Nomor Pokok Wajib Pajak. NPWP ini diterbitkan oleh petugas pajak yang diberikan pada wajib pajak yang nantinya digunakan untuk identitas wajib pajak serta proses administrasi selanjutnya. Dengan adanya NPWP ini petugas perpajakan bisa melakukan identifikasi bahwa kewajiban anda dalam membayar pajak ke negara sudah dipenuhi atau belum, dengan kata lain memiliki NPWP menjadikan pihak petugas pajak lebih mudah dalam memantau pajak yang wajib anda keluarkan dari kegiatan bisnis anda. Untuk memperoleh NPWP silahkan anda datang ke kantor Pajak dimana anda tinggal.

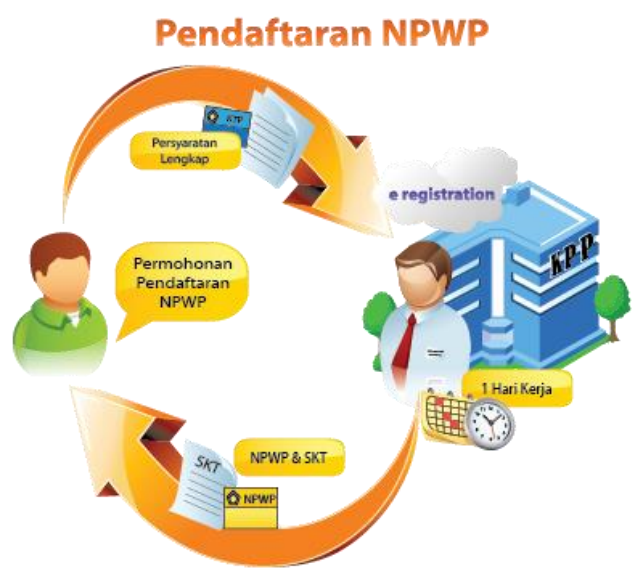

Gambar 9: Alur Pendaftaran NPWP (Maros, 2017) 


\section{Izin Usaha Dagang (UD)}

Salah satu usaha yang dikelola oleh perorangan ialah usaha dagang / perdagangan, walaupun begitu anda tetap harus melakukan perizinan usaha dagang sebagai bukti bahwa usaha atau bisnis anda adalah legal. Jadi sebagai pengusaha yang memiliki usaha kecil sebaiknya jangan menyepelekan dokumen penting yang satu ini. Nah untuk memperolehnya silahkan anda datangi kantor departemen perindustrian dan perdagangan di kota anda.

\section{Surat Izin Tempat Usaha (SITU)}

Setelah memiliki surat izin usaha dagang, surat atau berkas yang harus anda miliki selanjutnya ialah Surat Izin Tempat Usaha atau SITU, SITU adalah surat yang wajib dimiliki oleh pemilik usaha per seorangan maupun yang telah berbentuk badan usaha sebagai bukti yang menyatakan bahwa izin serta legalitas dari usaha yang kalian jalankan adalah legal. SITU ini memiliki dasar hukum yang sah sehingga memiliki SITU merupakan suatu kewajiban bagi anda pelaku bisnis usaha. Biasanya masa berlaku dari SITU ini kurang lebih selama 3 tahun, dan wajib diperpanjang jika masa berlakunya sudah kedaluarsa. Untuk syarat yang dibutuhkan dalam memperbaharui SITU tetap sama seperti ketika anda pertama kali membuatnya, dengan catatan usaha atau bisnis anda juga tidak mengalami perubahan. Proses pembuatan SITU bisa melalui camat maupun bupati dengan melampirkan semua persyaratan yang ada, untuk informasi lebih lanjut silahkan anda bertanya di kantor kecamatan setempat.

\section{Surat Izin Prinsip}

Surat izin prinsip ini di terbitkan oleh pemda dan diberikan pada pelaku usaha perseorangan maupun yang sudah berbentuk badan usaha yang ingin membangun usaha di lingkungan daerah tertentu. Nah dengan dokumen inilah nantinya sumber pendapatan daerah bisa diambil sebagai sumber investasi yang nantinya bisa bermanfaat bagi daerah dimana anda membuka usaha. Untuk memperoleh surat IP ini silahkan anda datangi Badan Perizinan Terpadu yang ada di tingkat kabupaten, kota atau provinsi dimana usaha anda didirikan. 


\section{Surat Izin Usaha Industri (SIUI)}

Surat SIUI ini diperuntukkan oleh mereka para pengusaha kecil menengah sebagai bentuk legalitas usaha yang dimaksudkan agar usaha yang mereka jalankan nantinya bisa beroperasi dan berjalan dengan lancar dan legal. Dokumen SIUI ini wajib dimiliki oleh pengusaha yang memiliki modal bisnis antara 5 juta hingga Rp 200 juta. Untuk memperoleh surat tersebut anda harus mengajukan permohonan ke kantor pelayanan dan perizinan terpadu yang ada di daerah tingkat II, Nantinya bila usaha atau bisnis yang anda kelola berkembang pesat, selanjutnya anda harus mengajukan SIUI ini di kantor pelayanan dan perizinan terpadu di daerah tingkat I. Untuk memperoleh surat SIUI ini berbeda beda di setiap daerah di indonesia, sehingga bila anda ingin membuat surat SIUI ini sebaiknya silahkan anda gali informasi mengenai apa saja persyaratan yang diperlukan untuk membuat SIUI ini di daerah anda, atau jika masih bingung anda bisa langsung datang dan menanyakan semua syarat yang dibutuhkan di kantor pelayanan perizinan terpadu.

\section{Surat Izin Usaha Perdagangan (SIUP)}

Jika pada surat SIUI yang membutuhkan adalah para pelaku usaha di bidang industri, maka untuk para pelaku usaha perdagangan membutuhkan surat perizinan yang disebut dengan Surat Izin Usaha Perdagangan atau SIUP. Surat ini dibuat dan diterbitkan oleh pemda yang ditujukan kepada mereka yang memiliki usaha di bidang perdagangan apapun jenisnya. Umumnya Surat Izin Usaha Perdagangan ini dibagi lagi kedalam 3 golongan yang diantaranya adalah sebagai berikut:

\begin{tabular}{|c|c|c|}
\hline SIUP Kecil & SIUP Menengah & SIUP Besar \\
\hline Diterbitkan untuk & Diterbitkan dan & Diterbitkan dan \\
perusahan di bidang & diperuntukkan kepada para & diperuntukkan kepada \\
perdagangan yang & pelaku usaha perdagangan & para pelaku usaha \\
mempunyai modal & yang mempunyai modal & perdagangan yang \\
serta kekayaan bersih & serta kekayaan bersih & mempunyai modal serta \\
dibawah Rp 200 juta & antara Rp 200 juta hingga & kekayaan bersih diatas Rp \\
diluar nilai lahan serta & Rp 500 juta diluar nilai & 500 juta diluar nilai lahan \\
bangunan tempat & lahan dan bangunan tempat & dan bangunan tempat \\
usaha. & usaha. & usaha. \\
\hline
\end{tabular}




\section{Tanda Daftar Perusahaan (TDP)}

Tanda Daftar Perusahaan atau TDP merupakan tanda bukti yang menyatakan bahwa usaha yang kalian kelola dan jalankan sudah terdaftar dan secara sah dapat beroperasi. Untuk memperoleh TDP ini bisa dilakukan sendiri maupun bisa diwakilkan ke orang lain dengan lampiran surat kuasa. Untuk jenis badan usaha yang wajib memiliki TDP adalah jenis badan usaha berbadan hukum seperti Firma. CV maupun PT, untuk usaha yang tidak termasuk kedalam usaha berbadan hukum tidak perlu mendaftarkan TDP. Untuk bisa memperoleh Tanda Daftar Perusahaan silahkan anda datangi kantor Dinas Industri dan Perdagangan yang ada di kabupaten atau kota dimana domisili perusahaan tersebut berada.

\section{Tanda Daftar Industri (TDI)}

Surat TDI adalah surat bukti perizinan bagi para pelaku usaha di bidang industri baik itu usaha kecil yang memiliki nilai investasi antara Rp 5 juta hingga Rp 200 juta diluar nilai lahan serta bangunan usaha. Untuk bisa memperoleh TDI ini sama, silahkan anda datang dan tanyakan semua persyaratan yang diperlukan untuk mengurus TDI di kantor Dinas Perindustrian yang ada di daerah atau kota anda.

\section{Surat izin gangguan ( HO )}

Surat izin gangguan HO ialah surat bukti pernyataan bahwa anda sebagai pengelola usaha tidak merasakan keberatan dengan situasi serta lokasi dimana anda mendirikan sebuah usaha. Surat izin gangguan ini diterbitkan oleh Dinas Perizinan Domisili Usaha yang ada di kabupaten atau kota. Perlu kalian ketahui juga bahwa nantinya pada saat anda membuat surat $\mathrm{HO}$, dinas perizinan akan memberikan beberapa persyaratan yang perlu anda penuhi dimana setiap daerah memiliki persyaratan yang berbeda beda. Pada umumnya surat HO ini dibutuhkan oleh para pelaku usaha yang ingin mendirikan tempat usaha di lokasi yang penuh dengan risiko serta bahaya yang tinggi dimana bisa mengganggu keamanan dan ketentraman masyarakat sekitar tempat usaha.

11. Surat Izin Mendirikan Bangunan (IMB)

Surat Izin Mendirikan Bangunan atau IMB ialah surat yang diterbitkan oleh pemerintah daerah yang diperuntukkan oleh para 
pengusaha baik yang belum atau sudah berbadan hukum yang nantinya akan mendirikan sebuah bangunan usaha sesuai dengan perizinan yang sudah diberikan. Nantinya saat IMB diterbitkan akan disertai retribusi yang berfungsi sebagai pungutan daerah atas izin yang telah pemerintah daerah berikan. Untuk besaran retribusi di masing-masing daerah tentunya berbeda beda. Dalam mengurus IMB anda bisa melakukannya secara online di www.dppb.go.idmaupun mendatangi langsung ke Kantor Dinas Tata Kota setempat.

\section{Izin BPOM}

Untuk surat perizinan yang terakhir ini dikhususkan bagi anda para pelaku usaha yang menjual produk makanan serta minuman atau produk konsumsi. Surat izin ini berfungsi untuk menjaga keamanan dan kelayakan konsumsi suatu produk makanan, minuman dan produk konsumsi lainnya seperti obat-obatan sehingga layak untuk diedarkan. Untuk memperoleh surat izin ini silahkan langsung datang saja ke kantor BPOM di kota anda.

\section{PAJAK}

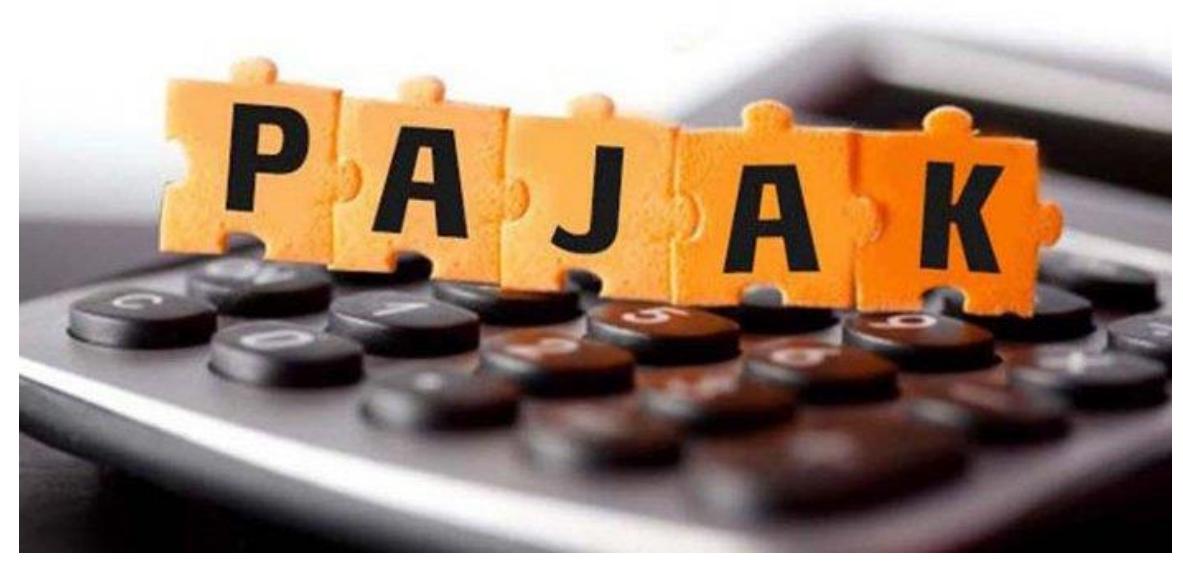

Gambar 10: Ilustrasi Pajak(Tribunnews, 2018) 
Pajak adalah sebuah kewajiban pembayaran iuran kepada kas negara yang harus dipenuhi oleh subjek pajak (istilah dalam peraturan perundangundangan perpajakan untuk perorangan (pribadi) atau organisasi (kelompok) berdasarkan peraturan perundang-undangan perpajakan yang berlaku) di suatu negara. Pengertian pajak dalam peraturan perundangundangan Negara Republik Indonesia tentang perpajakan, Pajak adalah kontribusi wajib kepada negara yang terutang oleh orang pribadi atau badan yang bersifat memaksa berdasarkan Undang-Undang, dengan tidak mendapatkan imbalan secara langsung dan digunakan untuk keperluan negara bagi sebesar-besarnya kemakmuran rakyat.(Undang-Undang Republik Indonesia Nomor 28 Tahun 2007 Tentang Perubahan Ketiga Atas Undang-Undang Nomor 6 Tahun 1983 Tentang Ketentuan Umum Dan Tata Cara Perpajakan, 2007) Pajak merupakan salah satu sumber pendapatan negara dan merupakan sektor pemasukan negara yang terbesar. Pajak digunakan untuk membiayai pembangunan infrastruktur negara serta kegiatan operasional negara. Di Indonesia pemungutan Pajak dilakukan berbeda bagi masing-masing objek pajak (Objek Pajak adalah hal-hal yang dikenai pajak).

Menurut Undang-undang Nomor 20 Tahun 2008 tentang Usaha Mikro Kecil Menengah, klasifikasi UMKM bisa dibedakan dari jumlah aset dan total omzet penjualan. Sedangkan menurut Badan Pusat Statistik, klasifikasi tersebut termasuk juga jumlah karyawan.(Pajak, 2018)
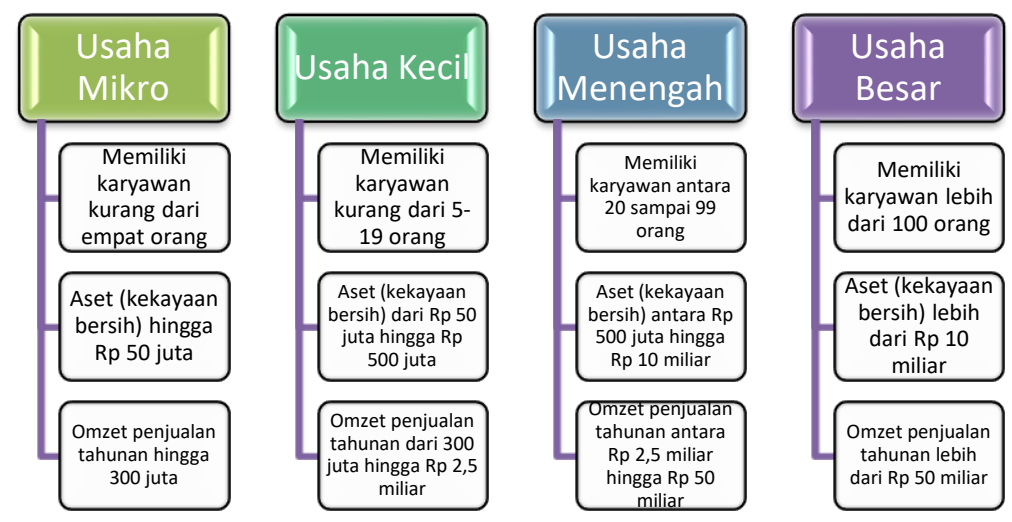
Menurut Peraturan Pemerintah Republik Indonesia Nomor 46 Tahun 2013, PPh Final untuk pajak UMKM adalah pajak atas penghasilan dari usaha yang diterima atau diperoleh Wajib Pajak (Wajib Pajak adalah orang pribadi atau badan yang menurut ketentuan peraturan perundang-undangan perpajakan ditentukan untuk melakukan kewajiban perpajakan, termasuk pemungut pajak atau pemotong pajak tertentu. Wajib pajak bisa berupa wajib pajak orang pribadi atau wajib pajak badan) yang memiliki peredaran bruto atau omzet di bawah Rp 4,8 miliar dalam setahun. Untuk pelaku Usaha Kecil, Mikro dan Menengah (UMKM) yang memiliki omzet maksimal Rp4,8 miliar dikenakan tarif sebesar 0,5\% yang berlaku mulai bulan Juli 2018 hingga sekarang. Tarif ini mengalami penurunan dari yang sebelumnya dikenakan tarif sebesar $1 \%$. Tidak jauh berbeda dengan usaha konvensional, usaha yang dijalankan secara online juga akan dikenai pajak. Permasalahan yang muncul adalah pada transaksi e-commerce berdampak pada pajak tidak langsung (indirect tax) dan pajak langsung (direct tax).(Sakti, 2014)

\section{HUKUM PENGANGKUTAN}

E-Commerce adalah sebuah model perdagangan tanpa batas, artinya transaksi yang dilakukan dapat dilakukan dimana saja dan kapan saja. Transaksi yang dimaksud tidak mengharuskan tatap muka antara pembeli dan penjual. Jika dalam model penjualan konvensional pembeli dan penjual saling berhadap-hadapan, maka transaksi pada $e$-commerce cukup dilakukan dengan menggunakan gadget. Kedua belah pihak akan menghemat waktu dan tenaga yang diakibatkan oleh jarak. Model transaksi jarak jauh yang dimudahkan berkat adanya e-commerce ini, memberi kemudahan dari kedua belah pihak yang bertransaksi dengan lebih efektif dan efisien. Penjual dapat memasarkan produk dengan jangkauan lebih luas. Dan dari sisi pembeli memiliki opsi lebih banyak atas jenis produk yang diinginkan.

Dengan adanya model transaksi tersebut perkembangan bisnis ecommerce berdampak positif pada peningkatan industri logistik. Salah satu perusahaan yang bergerak di bidang logistik adalah PT. JNE yang merupakan perusahaan jasa kurir pengiriman paket dalam wilayah lokal maupun internasional. Adanya Kebijakan MEA memberikan tantangan 
bagi JNE untuk bersaing menghadapi kompetitor dari negara-negara ASEAN, sehingga JNE harus mampu mempertahankan konsumennya dengan meningkatkan mutu pelayanan. Tujuan dari penelitian ini adalah mengidentifikasi dan menganalisis faktor-faktor yang memengaruhi keputusan konsumen dalam menggunakan JNE. Metode pengambilan sampel yang digunakan pada penelitian ini yaitu teknik kuota sampling. Data dianalisis menggunakan analisis deskriptif dan analisis faktor dengan bantuan software SPSS 22. Hasil penelitian ini menunjukkan bahwa ada 13 faktor yang memengaruhi pengambilan keputusan penggunaan JNE yaitu daya saing, motif dan persepsi, pekerjaan dan pelayanan, operasional, komunikasi dan pembelajaran, layanan tambahan, fasilitas layanan, demografi, gaya hidup, pengaruh lingkungan, kondisi, lingkungan fisik dan pengaruh media. Faktor paling dominan adalah daya saing dengan nilai persentase keragaman data mencapai 26,59\%. (M, 2016)

1) Pengertian dan ruang lingkup hukum pengangkutan

Pengertian umum pengangkutan adalah perpindahan orang dan/atau barang dari satu tempat ke tempat lain dengan menggunakan kendaraan di ruang lalu lintas jalan. Pada zaman modern saat ini pengangkutan mempunyai peranan yang penting dan strategis untuk mewujudkan keamanan, kesejahteraan, ketertiban berlalu lintas dan dalam rangka pembangunan ekonomi dan pengembangan ilmu pengetahuan dan teknologi, otonomi daerah serta akuntabilitas penyelenggaraan negara. Peranan yang sangat penting dan strategis dalam kehidupan masyarakat karena didasari oleh berbagai faktor, antara lain: keadaan geografis Indonesia, menunjang pembangunan di berbagai sector, mendekatkan jarak antara desa dan kota, perkembangan ilmu dan teknologi. Ruang lingkup hukum pengangkutan dalam penyelenggaraannya terdapat hubungan hukum antara pengangkut dengan penumpang atau pengirim barang, hubungan hukum tersebut tidak lain suatu perikatan antara pengangkut dengan penumpang.(Mustofa, 2011) 


\section{2) Asas-asas hukum pengangkutan}

\begin{tabular}{|c|c|c|}
\hline $\begin{array}{l}\frac{\text { Asas Dalam }}{\text { Hukum }} \\
\underline{\text { Pengangkutan }} \\
\end{array}$ & $\frac{\text { Penjelasan(Tambunan, Toman }}{\underline{\text { Sony; Tambunan, 2019) }}}$ & Contoh (Prayogo, 2014) \\
\hline $\begin{array}{l}\text { Asas Kepent- } \\
\text { ingan Umum }\end{array}$ & $\begin{array}{l}\text { Setiap pengangkut harus lebih } \\
\text { mengutamakan kepentingan } \\
\text { masyarakat luas daripada } \\
\text { kepentingan perseorangan atau } \\
\text { kelompok dengan memper- } \\
\text { hatikan keselamatan, kea- } \\
\text { manan, kenyamanan dan ket- } \\
\text { ertiban. }\end{array}$ & $\begin{array}{l}\text { PT. POS INDONESIA } \\
\text { memiliki cabang di seluruh } \\
\text { wilayah negara indonesia } \\
\text { guna melayani pengiriman } \\
\text { barang dan jasa demi } \\
\text { kepentingan bersama } \\
\text { masyarakat indonesia. }\end{array}$ \\
\hline Asas Manfaat & $\begin{array}{l}\text { Setiap pengangkut harus dapat } \\
\text { memberikan manfaat yang } \\
\text { sebesar-besarnya bagi kemanu- } \\
\text { siaan, peningkatan kemakmu- } \\
\text { ran rakyat, kesejahteraan } \\
\text { rakyat, dan pengembangan } \\
\text { kehidupan yang berkesinam- } \\
\text { bungan bagi warga negara. }\end{array}$ & $\begin{array}{l}\text { Adanya angkutan Umum Bus } \\
\text { Way di jakarta. Salah satu } \\
\text { solusi efektif dalam menga- } \\
\text { tasi kemacetan di jakarta. } \\
\text { Dimana dengan adanya Bus- } \\
\text { way, masyarakat jauh lebih } \\
\text { mudah dalam hal mengatasi } \\
\text { macet di jakarta sehingga } \\
\text { perekonomian juga bisa ber- } \\
\text { gerak lebih cepat. }\end{array}$ \\
\hline $\begin{array}{l}\text { Asas Usaha } \\
\text { Bersama dan } \\
\text { Kekeluargaan }\end{array}$ & $\begin{array}{l}\text { Penyelenggaraan usaha di } \\
\text { bidang pengangkutan dil- } \\
\text { aksanakan untuk mencapai } \\
\text { tujuan nasional yang dalam } \\
\text { kegiatannya dapat dilakukan } \\
\text { oleh seluruh lapisan masyarakat } \\
\text { dan dijiwai oleh semangat } \\
\text { kekeluargaan. }\end{array}$ & $\begin{array}{l}\text { Pengiriman uang melalui } \\
\text { WESTERN UNION. Dimana } \\
\text { dengan western union, pengi- } \\
\text { riman uang dapat di lak- } \\
\text { sanakan hampir di seluruh } \\
\text { wilayah indonesia guna men- } \\
\text { dukung kemakmuran } \\
\text { masyarakat indonesia melalui } \\
\text { kerja sama PT. POS INDO- } \\
\text { NESIA, Bank di seluruh } \\
\text { Indonesia, dan jasa } \\
\text { Pengangkutan darat, laut, } \\
\text { maupun udara. }\end{array}$ \\
\hline $\begin{array}{l}\text { Asas Adil dan } \\
\text { Merata }\end{array}$ & $\begin{array}{l}\text { Penyelenggaraan pengangkutan } \\
\text { harus dapat memberikan pela- } \\
\text { yanan yang adil dan merata } \\
\text { kepada segenap lapisan } \\
\text { masyarakat dengan biaya yang }\end{array}$ & $\begin{array}{l}\text { Merpati Airlines memiliki } \\
\text { beberapa pesawat perintis di } \\
\text { seluruh indonesia. Tetapi rute } \\
\text { terbanyak di tujukan kepada } \\
\text { rute ke pulau jawa. Dimana, }\end{array}$ \\
\hline
\end{tabular}




\begin{tabular}{|c|c|c|}
\hline$\frac{\underline{\text { Asas Dalam }}}{\underline{\text { Hukum }}}$ & $\frac{\text { Penjelasan(Tambunan, Toman }}{\underline{\text { Sony; Tambunan, 2019) }}}$ & $\underline{\text { Contoh (Prayogo, 2014) }}$ \\
\hline & $\begin{array}{l}\text { terjangkau oleh masyarakat } \\
\text { tanpa membedakan suku, } \\
\text { agama dan keturunan serta } \\
\text { tingkat ekonomi. }\end{array}$ & $\begin{array}{l}\text { mereka memberikan pelayan } \\
\text { terbaik bagi penumpangnya } \\
\text { dengan harga terjangkau. }\end{array}$ \\
\hline $\begin{array}{l}\text { Asas Keseim- } \\
\text { bangan }\end{array}$ & $\begin{array}{l}\text { Setiap Pengangkut harus } \\
\text { diselenggarakan atas dasar } \\
\text { keseimbangan antara sarana } \\
\text { dan prasarana, kepentingan } \\
\text { pengguna jasa dan penyeleng- } \\
\text { gara, kebutuhan dan ketersedi- } \\
\text { aan, kepentingan individu dan } \\
\text { masyarakat, antar daerah dan } \\
\text { antar wilayah, serta antara } \\
\text { kepentingan nasional dan inter- } \\
\text { nasional. }\end{array}$ & $\begin{array}{l}\text { Restruksi pelayanan Perkereta } \\
\text { Apian dewasa ini, dimana } \\
\text { mereka menaikkan harga tiket } \\
\text { kereta api dengan pening- } \\
\text { katan pelayanan di bidang } \\
\text { fasilitas gerbong, stasiun, dan } \\
\text { ticketing guna kenyamanan } \\
\text { dan keamanan pengguna jasa } \\
\text { kereta api. }\end{array}$ \\
\hline $\begin{array}{l}\text { Asas } \\
\text { Keterpaduan }\end{array}$ & $\begin{array}{l}\text { Pengangkutan harus merupakan } \\
\text { kesatuan yang bulat dan utuh, } \\
\text { terpadu, saling menunjang, dan } \\
\text { saling mengisi baik intra mau- } \\
\text { pun antar moda transportasi. }\end{array}$ & $\begin{array}{l}\text { Di dalam dunia penerbangan, } \\
\text { setiap pesawat maskapai } \\
\text { penerbangan wajib di cek } \\
\text { oleh petugas bandara, pilot } \\
\text { harus berkomunikasi dengan } \\
\text { pihak terminal bandara, dan } \\
\text { pihak terminal menentukan } \\
\text { jalur penerbangan, dimana } \\
\text { dari setiap elemen dalam } \\
\text { penerbangan harus selaras } \\
\text { dan berkesinambungan guna } \\
\text { meminimalisirkan setiap } \\
\text { resiko sekecil mungkin. }\end{array}$ \\
\hline $\begin{array}{l}\text { Asas } \\
\text { Kesadaran } \\
\text { Hukum }\end{array}$ & $\begin{array}{l}\text { Mewajibkan kepada pemerintah } \\
\text { untuk menegakkan dan menja- } \\
\text { min kepastian hukum serta } \\
\text { mewajibkan kepada setiap } \\
\text { warga negara Indonesia untuk } \\
\text { selalu sadar dan taat kepada } \\
\text { hukum dalam penyelenggaraan } \\
\text { pengangkutan. }\end{array}$ & $\begin{array}{l}\text { Truk pasir yang membawa } \\
\text { pasir gunung ketika melewati } \\
\text { jembatan timbang selalu } \\
\text { menimbangkan berat beban } \\
\text { kendaraannya dan mengi- } \\
\text { jinkan petugas mengecek } \\
\text { barang bawaannya. }\end{array}$ \\
\hline $\begin{array}{l}\text { Asas Percaya } \\
\text { Diri Sendiri }\end{array}$ & $\begin{array}{lll}\text { Pengangkutan } & \text { harus ber- } \\
\text { landaskan pada } & \text { kepercayaan }\end{array}$ & $\begin{array}{l}\text { Prima Taxi merupakan badan } \\
\text { usaha yang di izinkan memo- }\end{array}$ \\
\hline
\end{tabular}




\begin{tabular}{|l|l|l|}
\hline $\begin{array}{c}\text { Asas Dalam } \\
\text { Pukum } \\
\text { Pengangkutan }\end{array}$ & $\begin{array}{l}\text { Penjelasan(Tambunan, Toman } \\
\text { Sony; Tambunan, 2019) }\end{array}$ & Contoh (Prayogo, 2014) \\
\hline $\begin{array}{l}\text { akan kemampuan dan kekuatan } \\
\text { sendiri, serta bersendikan } \\
\text { kepada kepribadian bangsa. }\end{array}$ & $\begin{array}{l}\text { nopoli jalur taxi di bandara } \\
\text { juanda dimana badan usaha } \\
\text { tersebut berbentuk koperasi } \\
\text { PRIMKOPAL. }\end{array}$ \\
$\begin{array}{l}\text { Asas Kesela- } \\
\text { matan }\end{array}$ & $\begin{array}{l}\text { Setiap penyelenggaraan } \\
\text { pengangkutan penumpang } \\
\text { harus disertai dengan asuransi } \\
\text { kecelakaan. }\end{array}$ & $\begin{array}{l}\text { PT. Lion Air mengasuransi- } \\
\text { kan penumpangnya kepada } \\
\text { PT. Sinar Mas sebagai Perus- } \\
\text { ahaan Asuransi dimana } \\
\text { dengan tujuan menjamin } \\
\text { keselamatan penumpang } \\
\text { penerbangan udara yang } \\
\text { memakai Maskapai Lion Air. }\end{array}$ \\
\hline
\end{tabular}

3) Tanggung Jawab Pengangkut dalam Hukum Pengangkutan

Prinsip-Prinsip Tanggung Jawab Pengangkut Istilah tanggung jawab dalam arti liability dapat diartikan sebagai tanggung gugat yang merupakan terjemahan dari aansprakelijkheid, dan merupakan bentuk spesifik dari tanggung jawab hukum menurut hukum perdata. Tanggung gugat merujuk pada posisi seseorang atau badan hukum yang dipandang harus membayar suatu kompensasi atau ganti rugi setelah adanya peristiwa hukum. Menurut Frans G. Von der Dunk dari International Institute of Air and Space Law - Leiden University istilah liability yang dipersamakan dengan aansprakelijkheid dapat menimbulkan berbagai penafsiran: "Perhaps it may be added, that the Dutch language, although not an authentic language as far as the Outer Space Treaty is concerned, is also confusing in this respect. Whereas 'responsibility' should be translated as "verantwoordelijkheid" and 'liability' as "aansprakelijkheid", 'international state responsibility' turns out to be always translated as "staatsaanprakelijkheid". Dalam berbagai UU di bidang angkutan untuk hal ini selalu menggunakan istilah tanggung jawab, seperti dalam Undang-Undang Nomor 22 Tahun 2009, Undang-Undang Nomor 1 Tahun 2009 tentang Penerbangan dan Undang-Undang Nomor 17 Tahun 2008 tentang Pelayaran. Konsep dasar persoalan 
tanggung jawab apabila dihubungkan dengan suatu perbuatan melawan hukum, dapat dibedakan menjadi 2 (dua) macam prinsip tanggung jawab, yaitu: prinsip tanggung jawab berdasarkan kesalahan dan prinsip tanggung jawab tanpa kesalahan. Prinsip tanggung jawab berdasarkan kesalahan (fault liability principle) dapat lebih dirinci menjadi: Pertama, tanggung jawab berdasarkan kesalahan karena melakukan wanprestasi (tanggung jawab berdasarkan wanprestasi); Kedua, tanggung jawab berdasarkan kesalahan karena melakukan perbuatan melawan hukum, baik seperti yang dimaksud dalam Pasal 1365 KUH Perdata berdasarkan putusan Hoge Raad dalam kasus lindenbum versus cohen sejak tahun 1919 (tanggung jawab berdasarkan perbuatan melawan hukum), maupun karena melanggar peraturan perundang-undangan lainnya, seperti vicarious liability principle, liability based on fault principle, presumption of liability principle maupun presumption of non- liability principle. Sedangkan prinsip tanggung jawab tanpa kesalahan (no fault liability principle) dapat dibedakan menjadi 2 (dua) macam yaitu; strict liability principle dan absolute liability principle.(Nasution, 2014)

\section{PERJANJIAN DAGANG}

Perjanjian adalah peristiwa dua orang atau lebih saling berjanji untuk melakukan atau tidak melakukan suatu perbuatan tertentu, yang biasanya dibuat secara tertulis.(Sarno Wuragil, 2017) Istilah perjanjian berasal dari bahasa Belanda overeenkomst dan verbintenis. Dalam Kitab Undang-Undang Hukum Perdata digunakan istilah perikatan untuk verbintenis dan perjanjian untuk overeenkomst. Pengertian perjanjian menurut Pasal 1313 ayat (1) KUHPerdata disebutkan perjanjian adalah suatu perbuatan dengan mana satu orang atau lebih mengikatkan dirinya terhadap satu orang lain atau lebih. Dari pasal1313 ayat (1) KUH Perdata, dapat diketahui bahwa suatu perjanjian adalah suatu peristiwa di mana seorang berjanji kepada orang lain atau dimana dua orang atau lebih saling berjanji untuk melaksanakan suatu hal. Dari peristiwa tersebut timbul suatu hubungan antara dua orang atau lebih yang dinamakan perikatan. 
Terdapat berbagai bentuk perjanjian dalam bidang perdagangan, namun yang paling dominan muncul dalam transaksi online adalah sebagai berikut :

\section{a) Kontrak}

Kontrak atau perjanjian adalah suatu keadaan dimana kedua belah pihak atau lebih melakukan perjanjian yang bentuk-bentuknya tertulis untuk dilaksanakan bersama pada suatu kegiatan.(Tambunan, Toman Sony; Tambunan, 2019) Dengan demikian kontrak dapat menimbulkan hak dan kewajiban bagi para pihak yang membuat kontrak tersebut, karena kontrak yang mereka buat telah menjadi sumber hukum formal, asal kontrak tersebut adalah kontrak yang sah.(Sarno Wuragil, 2017)

Asas-asas kontrak: (Fuady, 2012)

a. Asas kontrak sebagai hukum yang mengatur. Yang dimaksud dengan hukum mengatur (aanvullen recht, optional law) adalah peraturan-peraturan hukum yang berlaku bagi subjek hukum. Para pihak yang mengikatkan diri dalam suatu kontrak akan terikat dan berjalan sesuai ketentuan hukum yang mengatur.

b. Asas kebebasan berkontrak (freedom of contract), yaitu konsekuensi dari berlakunya asas kontrak sebagai hukum mengatur. Asas kebebasan berkontrak adalah asas yang menekankan bahwa para pihak dalam suatu kontrak pada prinsipnya bebas untuk membuat atau tidak membuat kontrak, begitu juga dengan kebebasannya untuk mengatur sendiri isi kontrak tersebut.

c. Asas janji yang mengikat (pacta sunt servanda), yaitu suatu kontrak dibuat secara sah oleh para pihak mengikat para pihak tersebut secara penuh sesuai isi kontrak.

d. Asas konsensual, yaitu jika suatu kontrak telah dibuat, maka kontrak tersebut telah sah dan mengikat secara penuh, bahkan pada prinsipnya persyaratan tertulis pun tidak diisyaratkan oleh hukum.

e. Asas obligatoir, yaitu asas yang menentukan bahwa jika suatu kontrak telah dibuat maka para pihak telah terikat, tetapi 
keterikatannya itu hanya sebatas timbulnya hak dan kewajiban semata-mata.

f. Asas itikad baik, yaitu suatu kontrak yang dibuat dan disepakati oleh para pihak harus didasari dengan adanya itikad baik, baik sebelum kontrak dibuat, pada saat kontrak dibuat hingga pada saat berlakunya kontrak. Hal ini sesuai dengan pasal 1338 dalam KUH Perdata, yang isinya adalah: "Semua persetujuan yang dibuat bagi mereka yang membuatnya. Persetujuan itu tidak dapat ditarik kembali selain dengan kesepakatan kedua belah pihak, atau karena alasan-alasan yang ditentukan oleh undangundang. Persetujuan harus dilaksanakan dengan itikad baik."

Dan di dalam transaksi online terdapat istilah kontrak elektronik. Kontrak elektronik merupakan salah satu bentuk kontrak baru yang mendapatkan perlindungan secara khusus dalam Undang-Undang Nomor 11 Tahun 2008 tentang Informasi dan Transaksi Elektronik (yang selanjutnya disebut UU ITE), khususnya melalui Pasal 1 angka 17, kontrak elektronik adalah perjanjian para pihak yang dibuat melalui sistem elektronik. Sedangkan sistem elektronik itu sendiri adalah serangkaian perangkat dan prosedur elektronik yang berfungsi mempersiapkan, mengumpulkan, mengolah, menganalisis, menyimpan, menampilkan, mengumumkan, mengirimkan, dan atau menyebarkan informasi elektronik. Hal ini diatur dalam Pasal 1 angka 5 UU ITE.(Roosdiyana, 2010)

\section{b) Memorandum of Understanding (MoU)}

$\mathrm{MoU}$ adalah perjanjian pendahuluan, dalam arti nantinya akan diikuti dan dijabarkan dalam perjanjian lain yang mengaturnya secara detail, karena itu, Memorandum of Understanding berisikan hal-hal yang pokok saja. Adapun mengenai aspek lain-lain dari MoU relatif sama dengan perjanjian lainnya.(Fuady, 2012) 


\begin{tabular}{|c|c|c|}
\hline \multicolumn{3}{|c|}{ Secara singkat tentang Memorandum of Understanding (MoU)(Maxmanroe, n.d.) } \\
\hline 1. & Ciri-Ciri MoU & $\begin{array}{l}\text { - Umumnya isi MoU dibuat secara ringkas, bahkan } \\
\text { seringkali hanya dibuat satu halaman saja. } \\
\text { - Isi di dalam MoU adalah hal-hal yang sifatnya } \\
\text { pokok atau umum saja. } \\
\text { - MoU sifatnya pendahuluan, dimana akan diikuti } \\
\text { oleh kesepakatan lain yang isinya lebih detail. } \\
\text { - MoU jangka memiliki jangka waktu yang cukup } \\
\text { singkat, misalnya sebulan hingga satu tahun. Jika } \\
\text { tidak ada tindak lanjut dengan perjanjian yang lebih } \\
\text { ringci dari kedua belah pihak, maka nota } \\
\text { kesepakatan tersebut batal. } \\
\text { - Umumnya nota kesepahaman dibuat dalam bentuk } \\
\text { perjanjian di bawah tangan. } \\
\text { - MoU digunakan sebagai dasar untuk membuat } \\
\text { perjanjian untuk kepentingan banyak pihak, } \\
\text { misalnya investor, kreditor, pemegang saham, } \\
\text { pemerintah, dan lainnya. }\end{array}$ \\
\hline 2. & Tujuan MoU & $\begin{array}{l}\text { - Memudahkan Proses Pembatalan Suatu } \\
\text { Kesepakatan } \\
\text { - Sebagai Ikatan yang Sifatnya Sementara } \\
\text { - Sebagai Pertimbangan dalam Kesepakatan } \\
\text { - Sebagai Gambaran Besar Kesepakatan }\end{array}$ \\
\hline 3. & Manfaat MoU & $\begin{array}{l}\text { - Manfaat Yuridis: adanya kepastian hukum bagi } \\
\text { kedua belah pihak yang membuat kesepakatan. } \\
\text { Selain itu, MoU dapat berlaku sebagai Undang- } \\
\text { Undang bagi setiap pihak yang membuatnya. } \\
\text { - Manfaat Ekonomis: adanya penggerakan hak milik } \\
\text { sumber daya yang awalnya nilai penggunaannya } \\
\text { rendah menjadi lebih tinggi setelah adanya MoU. }\end{array}$ \\
\hline 4. & $\begin{array}{l}\text { Penambahan } \\
\text { Konsekuensi } \\
\text { Hukum Pada MoU } \\
\text { (bersifat opsional) }\end{array}$ & $\begin{array}{l}\text { - Agar kedua belah pihak terhindar dari } \\
\text { ketidakseriusan salah satu pihak pembuat MoU, } \\
\text { misalnya membatalkan kesepakatan secara sepihak } \\
\text { tanpa alasan yang jelas. } \\
\text { - Agar kedua belah pihak terhindar dari berbagai } \\
\text { kerugian, baik finansial maupun non finansial yang } \\
\text { telah dikeluarkan pihak-pihak tersebut. } \\
\text { - Untuk menjaga kerahasiaan informasi/ data yang } \\
\text { diberikan selama kegiatan pra kontrak. }\end{array}$ \\
\hline
\end{tabular}




\section{c) $\underline{\text { Term } n \text { Conditions }}$}

Syarat-syarat dan kondisi merupakan ketentuan-ketentuan dalam suatu perjanjian berupa persyaratan, kondisi dan jaminan-jaminan tertentu yang harus dipenuhi oleh kedua pihak.(Kamusbesar, n.d.) Dalam dunia bisnis online dimana jual-beli tidak terjadi dalam pertemuan yang intens, maka terms and conditions ini sangat berguna bagi kedua belah pihak untuk menghindari hal-hal yang tidak diharapkan. Dengan adanya syarat dan ketentuan yang jelas akan tercipta prosedur pembelian toko online yang disepakati antara penjual dan pemilik toko online itu sendiri dan pembeli. Persetujuan terhadap terms and onditions dapat menjadi suatu kontrak yang mengikat antara pihak penjual dan pembeli sebuah penyedia layanan.(V. Indonesia, 2020)

Dari paparan diatas manakah jenis perjanjian perdagangan yang patut diketahui pelaku usaha dan manakah yang paling tepat dipergunakan dalam bisnis e-commerce terkait usaha UMKM, pelaku usaha dapat memilih opsi terbaik dengan tetap mengindahkan asasasas hukum yang terkandung didalamnya.

\section{PERLINDUNGAN KONSUMEN}

Prinsip-prinsip hukum perlindungan konsumen, secara garis besar hal-hal yang diatur di dalam Undang-Undang Perlindungan Konsumen(Undang-Undang Perlindungan Konsumen, 1999) terkait dengan perlindungan terhadap konsumen dari sisi hak dan kewajiban konsumen dapat dirumuskan sebagai berikut: (YLKI, 2017)

\section{HAK KONSUMEN:}

1. Hak atas kenyamanan, keamanan, dan keselamatan dalam mengkonsumsi barang dan/atau jasa;

2. Hak untuk memilih barang dan/atau jasa serta mendapatkan barang dan/atau jasa tersebut sesuai dengan nilai tukar dan kondisi serta jaminan yang

3. dijanjikan;

Hak atas informasi yang benar, jelas, dan jujur mengenai kondisi dan jaminan

4. barang dan/atau jasa;

5. Hak untuk didengar pendapat dan keluhannya atas barang dan/atau jasa yang digunakan;

6 Hak untuk mendapatkan advokasi, perlindungan, dan upaya penyelesaian

44 Ni Putu Suci Meinarni ... [et al.] 


\begin{tabular}{|c|c|}
\hline \multicolumn{2}{|r|}{ HAK KONSUMEN: } \\
\hline 7. & sengketa perlindungan konsumen secara patut; \\
\hline 8 . & Hak untuk mendapat pembinaan dan pendidikan konsumen; \\
\hline & $\begin{array}{l}\text { Hak untuk diperlakukan atau dilayani secara benar dan jujur serta tidak } \\
\text { diskriminatif; }\end{array}$ \\
\hline 9. & $\begin{array}{l}\text { Hak untuk mendapatkan kompensasi, ganti rugi dan/atau penggantian, apabila } \\
\text { barang dan/atau jasa yang diterima tidak sesuai dengan perjanjian atau tidak } \\
\text { sebagaimana mestinya; }\end{array}$ \\
\hline & Hak-hak yang diatur dalam ketentuan peraturan perundang-undangan lainnya. \\
\hline \multicolumn{2}{|r|}{ KEWAJIBAN/TANGGUNG JAWAB KONSUMEN: } \\
\hline 1. & $\begin{array}{l}\text { Membaca atau mengikuti petunjuk informasi dan prosedur pemakaian atau } \\
\text { pemanfaatan barang dan/atau jasa, demi keamanan dan keselamatan; }\end{array}$ \\
\hline 2. & Beritikad baik dalam melakukan transaksi pembelian barang dan/atau jasa; \\
\hline 3. & Membayar sesuai dengan nilai tukar yang disepakati; \\
\hline 4. & $\begin{array}{l}\text { Mengikuti upaya penyelesaian hukum sengketa perlindungan konsumen } \\
\text { secara patut. }\end{array}$ \\
\hline
\end{tabular}

Paparan mengenai hal-hal yang disampaikan diatas juga terkait dengan beberapa asas yang dianut dalam perlindungan konsumen, yaitu:

\begin{tabular}{|c|c|c|}
\hline & Asas Manfaat & $\begin{array}{l}\text { : Bahwa perlindungan terhadap konsumen } \\
\text { harus memberikan manfaat baik bag }\end{array}$ \\
\hline$\Rightarrow$ & Asas Keadilan & $\begin{array}{l}\text { Konsumen dan pelaku usaha dalam rangka } \\
\text { mensukseskan perekonomian nasional } \\
\text { memiliki kesempatan untuk memperoleh } \\
\text { hak dan melaksanakan kewajibannya. }\end{array}$ \\
\hline$=$ & $\begin{array}{l}\text { Asas } \\
\text { Keseimbangan }\end{array}$ & $\begin{array}{l}\text { Konsumen, pelaku usaha serta pemerintah } \\
\text { dalam menjalankan asas keadilan secara } \\
\text { harmonis sehingga tercipta keseimbangan } \\
\text { ekonomi nasional. }\end{array}$ \\
\hline$\Rightarrow$ & $\begin{array}{l}\text { Asas Keamanan \& } \\
\text { Keselamatan } \\
\text { Konsumen }\end{array}$ & $\begin{array}{l}\text { Adanya jaminan terhadap konsumen } \\
\text { keamanan dan keselamatan dalam sebaga } \\
\text { pengguna barang/jasa. }\end{array}$ \\
\hline$\Rightarrow$ & Kepastian Hukum & $\begin{array}{l}\text { Konsumen dijamin haknya sebagai bagian } \\
\text { dari masyarakat hukum Indonesia, dalam } \\
\text { rangka penegakan supremasi hukum. }\end{array}$ \\
\hline
\end{tabular}


Sebagai pelaku usaha, perlindungan merupakan salah satu dari kepuasan pelanggan. Kepuasan pelanggan harus terjamin untuk pertumbuhan bisnis yang berkesinambungan.

$46 \square$ Ni Putu Suci Meinarni ... [et al.] 


\section{BAB IV \\ PELUANG DAN TANTANGAN}

\section{PASAR DALAM NEGERI}

Pasar adalah tempat pertemuan antara penjual dan pembeli, atau lebih jelasnya, daerah, tempat, wilayah, area yang mengandung kekuatan permintaan dan penawaran yang saling bertemu dan membentuk harga.(M. Fuad, Christine H, Nurlela, 2000) Pasar mencakup keseluruhan Permintaan dan penawaran, seluruh kontak atau interaksi antara penjual dan pembeli.(Gilarso, 2003)

Salah satu transaksi perdagangan yang potensial dapat digarap melalui platform e-Commerce adalah UMKM. Barang dan jasa UMKM memberikan kontribusi besar untuk memenuhi kebutuhan domestik dan ekspor. GerobakOnline .Com sebagai perusahaan start up e-Commerce memiliki visi dan misi untuk menjadi perusahaan marketplace terkemuka melayani UMKM. Penelitian kualitatif bertujuan untuk mendapatkan pemahaman dan gambaran secara menyeluruh mengenai model bisnis dan strategi GerobakOnline. Hasil dari penelitian menunjukkan bahwa GerobakOnline sebagai perusahaan start up e-Commerce memiliki 6 strategi inti pengembangan bisnis untuk meraih visi dan misi yang memberi solusi dan nilai tambah kepada pasar UMKM. Model bisnis GerobakOnline sejalan dengan 6 strategi inti perusahaan. Tiga pilar model bisnis: Infrastructure Management, Product Innovation, dan Customers Relationship menunjukkan bagaimana perusahaan melalui semua aspek memberikan value sebesar-besarnya kepada UMKM sebagai target mitra bisnis. Financial Aspect sebagai pilar ke empat menunjukkan struktur 
biaya lebih besar dari aliran pendapatan yang disebabkan oleh beban biaya penyusutan dan biaya pengembangan TI.(Nizar, 2017)

Presiden Republik Indonesia Joko Widodo telah mendeklarasikan visi untuk menjadikan Indonesia sebagai 'The Digital Energy of Asia' di Silicon Valley pertengahan Februari tahun ini. Sejalan dengan visi tersebut, Kementerian Komunikasi dan Informatika bersama KIBAR, menginisiasi Gerakan Nasional 1.000 Startup Digital dengan tujuan melahirkan perusahaan rintisan yang berkualitas dan memberikan dampak positif dengan menyelesaikan permasalahan besar di Indonesia. Gerakan ini ditargetkan dapat menciptakan 1.000 perusahaan baru dengan total valuasi bisnis senilai USD 10 miliar pada tahun 2020.(Kominfo, 2016)

Begitu optimisnya pemerintah dalam mendukung perkembangan digital marketing tanah air dapat pula kita lihat dari data Kementerian Koordinator Bidang Perekonomian (Kemenko Perekonomian) jumlah UMKM yang sudah memanfaatkan layanan digitalisasi baru mencapai 13 persen. "Artinya ini masih jauh, jumlah UMKM yang memanfaatkan digitalisasi untuk memperluas cakupan bisnis di dalam negeri," ujarnya. Terlebih, sambung Aviliani, pada tahun 2030 nanti pemerintah melalui Kemenko Perekonomian memproyeksikan ada 135 juta penduduk Indonesia akan memiliki penghasilan bersih diatas USD 43.600 sebagai konsumen. Imbasnya tingkat konsumsi masyarakat diyakini akan terus melonjak hingga berkali lipat. Kemudian, pada tahun yang sama pemerintah juga memprediksi jumlah usia penduduk produktif mencapai 60 persen, 27 persen diantaranya adalah penduduk muda dengan rentang usia 16-30 tahun. "Creative class ini akan juga melahirkan permintaan tinggi akan produk kreatif. Terutama produk yang berbasis media dan ICT (content industry)," tegasnya. Untuk itu, pemerintah baik pusat ataupun daerah didorong perlu memberikan dana alokasi khusus bagi pelatihan pengembangan strategi bisnis UMKM di dalam negeri. Dengan menekankan pemanfaatan digitalisasi dan standarisasi produk berkualitas ekspor.(Liputan6.com, 2020) 


\section{DISTRIBUSI PRODUK UMKM}

Media distribusi paling mudah yang dapat dimanfaatkan oleh pelaku usaha UMKM untuk saat ini adalah Marketplace. Marketplace adalah bagian dari e-commerce, media online berbasis internet (berbasis web) tempat aktivitas bisnis dan transaksi antara pembeli dan penjual. Pembeli dapat menemukan pemasok sebanyak mungkin dengan kriteria yang diinginkan, sehingga mendapatkan harga pasar yang sesuai.(Alam, 2020) Transaksi yang terjadi di dalam marketplace dikelola langsung oleh pihak manajemen marketplace.

Marketplace menyediakan pengelolaan pembayaran, katalog penjualan, stok produk dan informasi mengenai pembeli dan penjual yang sudah diverifikasi oleh pihak manajemen. (Rumondang, Astri; Sudirman, Acai; Sitorus, Samsider; Kusuma, Aditya Halim Perdana; Manuhutu, Melda; Sudarso, Andriansan; Simarmata, Janner; Tasnim, Dian Hasdiana; Arif, 2020) Sehingga penjual tidak perlu lagi membuat website tersendiri untuk model e-commerce. Terdapat banyak sekali perusahaan marketplace yang dapat dipilih untuk menjual produk. Penjual bahkan dapat memilih lebih dari satu tempat untuk lapak dagangannya. Berdasarkan data yang diperoleh dari www.greenhouse.co, Tokopedia menduduki peringkat teratas sebagai marketplace yang paling banyak dikunjungi. Data tersebut dapat dijadikan acuan oleh penjual untuk memilih marketplace terbaik untuk produk mereka. 


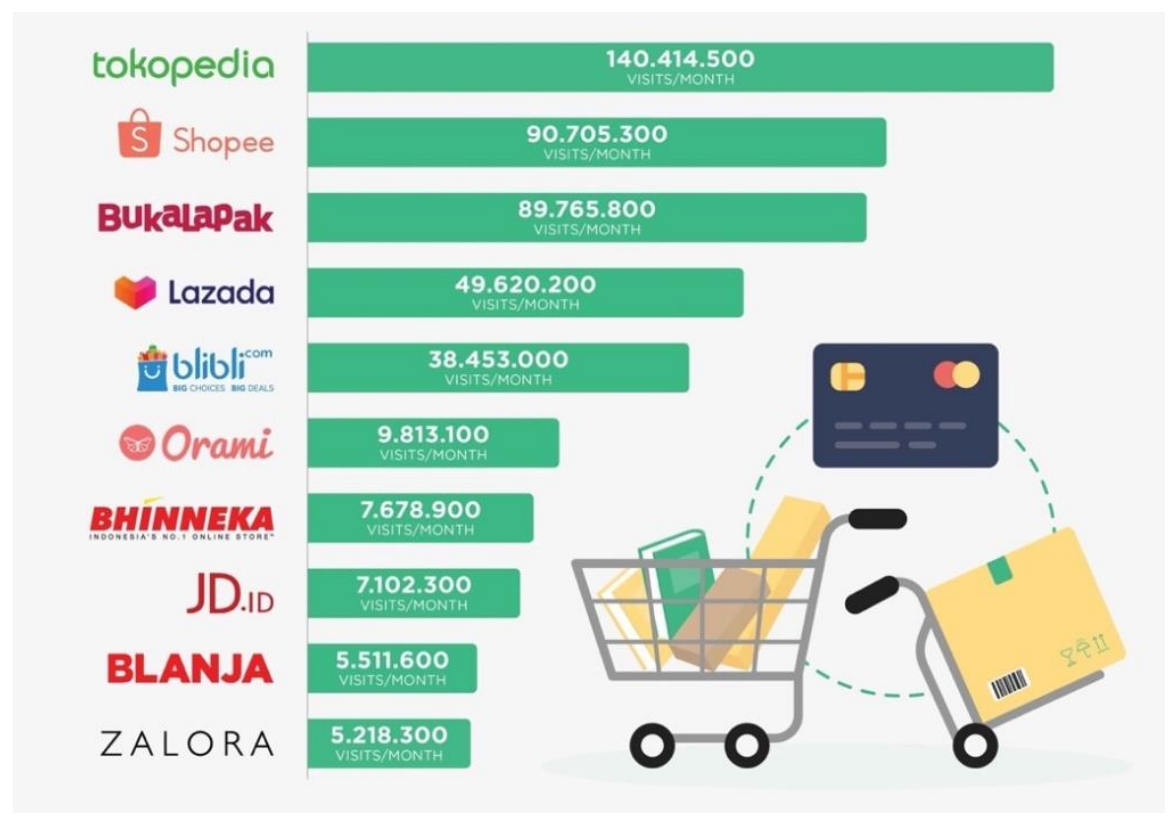

Gambar 11: Sepuluh Marketplace terbesar di Indonesia, diukur berdasarkan jumlah pengunjung pada kuartal kedua tahun 2019.

(Greenhouse, 2019)

Selain marketplace yang terdapat di Indonesia, pelaku usaha juga dapat memasarkan barangnya pada marketplace yang jangkauannya global. Misalnya penjual ingin memasarkan produknya di kawasan Asia Pasifik, untuk Kawasan tersebut beberapa marketplace yang dapat dipilih diantaranya: AliExpress, Amazon China, Fruugo, Taobao, TMall, TradeMe dan masih banyak lagi. Namun perlu diketahui, untuk mengantarkan produk pada ranah global dibutuhkan beberapa pengetahuan umum mengenai perdagangan internasional yang tertuang pada kebijakan GATT dan WTO.

Pola distribusi konvensional terdahulu yang menjadi hambatan dalam proses bisnis kini tidak lagi menjadi permasalahan yang berat. Dengan adaptasi yang dimiliki oleh para pelaku transaksi digital maka bermunculan berbagai solusi-solusi dalam pendistribusian barang yang lebih efektif dan efisien. Salah satunya metode pengiriman barang pada marketplace yang sebagian bersifat swakelola, sehingga memudahkan 
pertumbuhan bisnis penjual itu sendiri. Dan dari sisi kepuasan pelanggan, metode ini dapat pula meningkatkan kepercayaan pelanggan untuk melakukan pemesanan kembali.

Solusi distribusi barang nampaknya memunculkan kekhawatiran, salah satunya ialah tentang ketidak sesuaian barang yang dikirimkan ataupun kerusakan. Namun bagi konsumen yang telah menyadari konsekuensi dari pembelian barang secara online tidak terlalu mempermasalahkan mengenai komplain barang yang dibeli melalui proses transaksi online, hal tersebut dikarenakan oleh beberapa hal:(I Putu Gede Budayasa, I Gede Totok Suryawan, Ni Putu Suci Meinarni, 2018)

1. Proses manajemen yang panjang

2. Penambahan ongkos kirim untuk pengembalian barang

3. Keengganan untuk menunggu respon dari penjual

4. Pelanggan menganggap waktu, tenaga dan pikiran yang tercurah tidak sebanding dengan harga barang

5. Selain itu peran jasa pengiriman dalam distribusi dapat dijabarkan sebagai berikut:(Lalamove, 2020)

\section{Digitalisasi}

Adanya pandemi Covid-19 mendorong proses digitalisasi di berbagai sektor bisnis. Banyak bisnis beralih ke platform bisnis online dan ecommerce agar mampu bertahan. Dengan jasa pengiriman yang ikut terdigitalisasi, pebisnis dapat merasakan otomatisasi dan transparansi melalui pelacakan kendaraan secara real-time, pengarsipan online yang menyeluruh, dan komunikasi dengan driver yang efisien. Hal ini memudahkan bisnis untuk mengambil peran yang lebih aktif dalam proses pengelolaan logistik mereka.

\section{Fleksibel}

Bisnis UKM memiliki potensi untuk bergerak lebih cepat terhadap perubahan yang ada. Di sisi lain, banyak UKM yang menghadapi kesulitan untuk mengakses modal dan skill. Kekurangan ini dapat menghambat bisnis UKM untuk membuat perubahan atau beradaptasi dengan perubahan seperti yang bisa dilakukan oleh perusahaan besar. 
Dengan layanan pengiriman barang on-demand dan terjadwal, pebisnis UKM bisa lebih fleksibel dalam menjalankan bisnis mereka dan beradaptasi dengan lebih mudah. Selain itu, jasa logistik yang terjangkau membantu UKM untuk menghemat biaya operasional.

\section{Jangkauan yang Lebih Luas}

Berinvestasi pada kendaraan maupun tenaga kerja untuk melakukan pengiriman memerlukan biaya yang tak sedikit. Hal ini seringkali menjadi kendala bagi UKM khususnya bagi bisnis yang sedang berusaha untuk mengembangkan jangkauannya.

Jasa pengiriman barang dengan driver yang berpengalaman dan pilihan armada yang beragam dapat membantu UMKM meningkatkan layanan pengiriman mereka. Tanpa perlu berinvestasi pada tenaga kerja dan kendaraan untuk pengiriman, pebisnis bisa lebih fleksibel mengatur alokasi dana untuk pengiriman. Saat permintaan sedang tinggi, pebisnis bisa dengan mudah meningkatkan pengiriman tanpa perlu mengeluarkan modal lebih.

\section{PASAR GLOBAL}

Sejarah Perdagangan Internasional

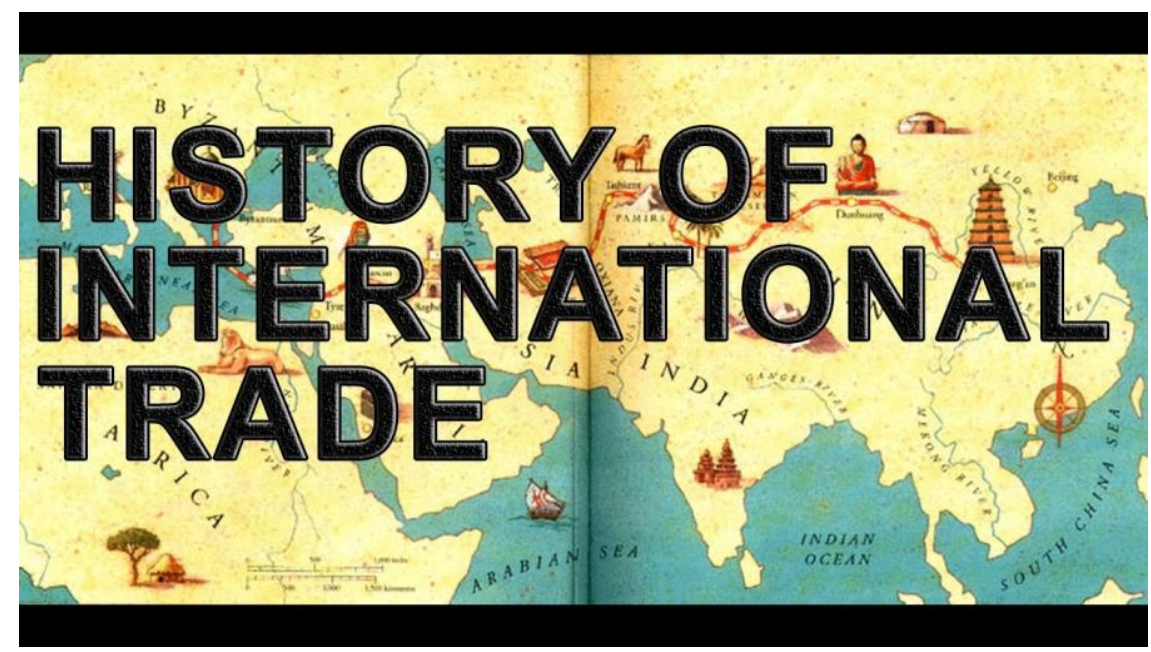

Gambar 12: Ilustrasi Sejarah Perdagangan Internasional.(Highligth Pertukaran Cloth and Food, n.d.) 
Dahulu kala, transaksi dalam bidang perdagangan dilakukan dengan cara tukar menukar barang atau pun jasa yang dikenal dengan istilah barter. Kemudian gagasan mengenai mata uang muncul untuk melakukan efisiensi dan efektivitas dari transaksi ekonomi. Namun, tidak semua barang yang kita inginkan bisa didapat dengan cara barter, melainkan harus ada kesepakatan dengan orang lain mengenai barang yang akan ditukar. Berbeda dengan saat ini, seseorang bisa membeli apa saja jika punya uang. Barter juga menjadikan manusia lebih selektif dalam mendapatkan barang sehingga kualitas barang bisa terjaga dengan baik. Sistem barter dapat pula menipiskan kesenjangan sosial antara si kaya dan si miskin dalam kehidupan. Kemunculan uang pertama di peradaban manusia masih diperdebatkan lantaran ada beberapa versi. Jack Weatherford dalam buku History of Money (1997), misalnya, mendukung pendapat yang mengatakan bahwa uang pertama kali diciptakan dan digunakan oleh bangsa atau orang-orang dari Kerajaan Lydia.(Tirto.id, 2019)

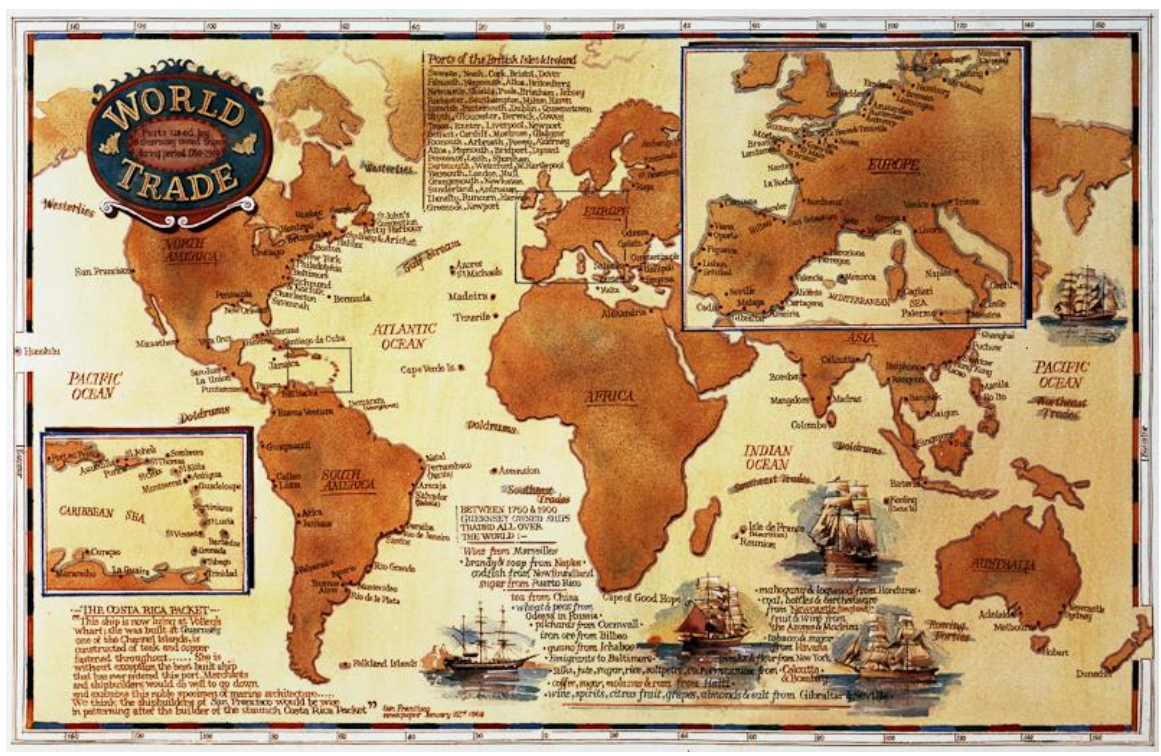

Gambar 13: Ilustrasi rute perdagangan internasional.(Sciencetechnologyandhealth.wordp, 2016) 


\section{SEJARAH SINGKAT RUTE PERDAGANGAN INTERNASIONAL}

Transaksi perdagangan internasional sudah dimulai ribuan tahun yang lalu. Bahkan terdapat catatan mengenai perdagangan internasional tersebut sudah terjadi sebelum masa Yesus Kristus. Perdagangan kuno dilakukan dalam skala yang besar. Di daerah eropa dan timur tengah proses perdagangan masa lampau ditandai dengan gaya transportasi menggunakan bantuan hewan seperti kuda dan unta. Perjalanan yang dilalui oleh model perdagangan ini cukup jauh dengan medan yang juga sulit. Dan pada masa kini seiring perkembangan teknologi, model transportasi yang digunakan jauh lebih canggih sehingga segala sesuatunya jauh lebih efektif. Hanya saja terdapat regulasi-regulasi yang harus disepakati antar pedagang antar negara di seluruh dunia.

\section{Jalur Sutra}

Salah satu jalur perdagangan tertua di dunia adalah jalur sutra. Jalur ini merupakan rute penghubung antar negara di beberapa benua, diantaranya: negara-negara Eropa, Arab, Persia dan China. Secara tidak langsung jalur ini juga membuka jalur cabang ke wilayah Asia Tenggara. Perdagangan melalui jalur sutra telah ada sejak tahun 200 SM, dengan panjangnya rute kurang lebih $6.500 \mathrm{~km}$. Selama 600 tahun rute perdagangan ini membawa dampak yang positif bagi profit para pedagang. Selain itu perdagangan juga memberi pengaruh bagi kebudayaan bagi negara-negara sekitar. Contoh negara Indonesia, memiliki kebudayaan yang sangat diperngaruhi oleh beberapa negara Asia dan Arab. 




Gambar 14 : Jalur Sutra.(Encyclopedia, 2018)

\section{Terusan Panama}

Jalur perdagangan di belahan bumi lainnya adalah terusan Panama. Terusan ini terbentang di Amerika sepanjang $82 \mathrm{~km}$, memotong Amerika Utara dan Amerika Selatan serta menghubungkan Samudra Pasifik dan Atlantik. Terusan ini memotong waktu tempuh kapal laut karena tidak perlu memutar lewat ujung selatan Amerika Selatan.(Wikipedia, 2019) Pembangunan terusan ini sudah mulai muncul pada tahun 1500-an namun baru dibuka pada 15 Agustus 1914. Terusan ini telah membantu 800.000 kapal menyeberang sejak pembukaannya atau 12.000 kapal per tahun. 


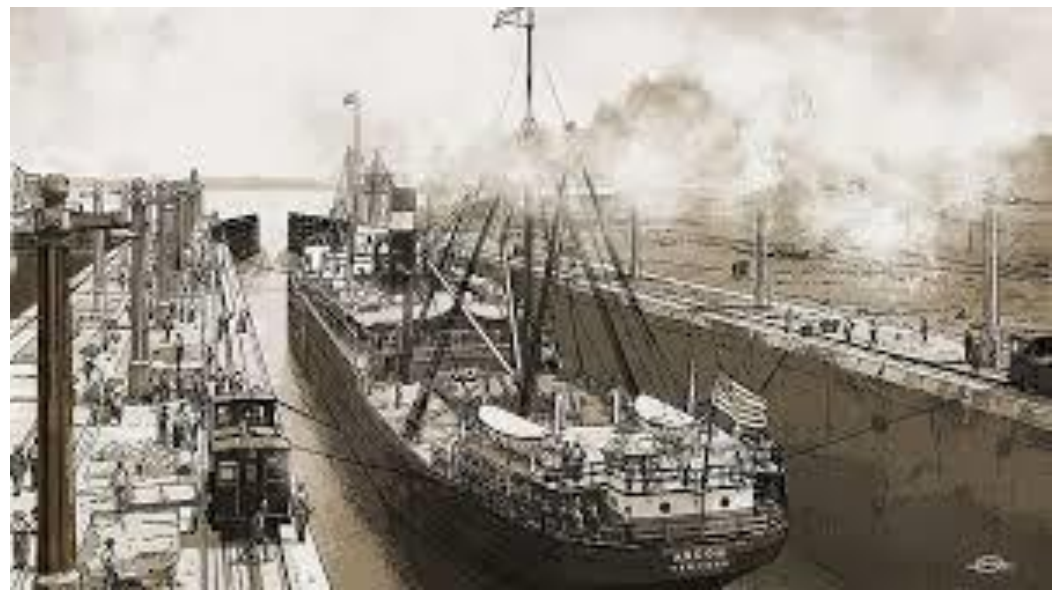

Gambar 15 : Terusan Panama.(Allianz, 2014)

\section{Perkembangan Perdagangan di Indonesia}

Indonesia sebagai poros maritim dunia memiliki keuntungan dari letak geografisnya dalam bidang perdagangan. Sejak zaman nenek moyang, Indonesia telah memiliki potensi tersebut. Berikut penjelasan mengenai perkembangan hubungan dagang internasional Indonesia dari masa ke masa:

1. Masa Klasik

: Pada masa ini dikenal sebagai masa kerajaan di Indonesia. Terdapat dua kerajaan besar di Indonesia pada masa, yaitu kerajaan Sriwijaya (abad ke-8 masehi) dan kerajaan Majapahit (abad ke-13 masehi). Kedua kerajaan tersebut terkenal dengan armada maritim yang kuat. Selain itu kerajaan Sriwijaya dan kerajaan Majapahit juga terkenal sebagai pedagang yang mahsyur dan telah melakukan transaksi dagang internasional di wilayah Asia Tenggara.

2. Masa Kolonial : Di abad ke-16 masehi, negara-negara barat melakukan ekspansi besar-besaran untuk menambah wilayah jajahannya. Negara barat merasa percaya diri melakukan penjajahan 
3. Masa Orde Lama

4. Masa Order Baru tersebut karena pada masa itu negara-negara tersebut memiliki armada niaga dan militer yang lebih kuat dan peralatan yang modern. Alasan mendasar yang menjadikan negaranegara barat melakukan ekspansi adalah penguasaan atas rempah-rempah di wilayah Asia Tenggara, terutama Indonesia.

: Deklarasi Djuanda merupakan titik awal perjuangan bangsa Indonesia di bidang kelautan. Deklarasi Djuanda adalah cikal bakal dari konvensi hukum laut internasional. Hal-hal yang diperjuangkan dalam deklarasi terkait kedaulatan bangsa Indonesia atas wilayah perairannya.

: Masa kemunduran perdagangan namun kejayaan hukum laut, karena disahkannya United Nations on The Law of The Sea (UNCLOS) dimana Deklarasi Juanda merupakan salah satu cikal bakal dari dibentuknya UNCLOS. Pada masa ini pula ditetapkan sebagai alur untuk pelaksanaan Hak Lintas Alur Laut Kepulauan berdasarkan konvensi hukum laut internasional. Alur ini merupakan alur untuk pelayaran dan penerbangan yang dapat dimanfaatkan oleh kapal atau pesawat udara asing diatas laut tersebut untuk dilaksanakan pelayaran dan penerbangan damai dengan cara normal. Penetapan ALKI dimaksudkan agar pelayaran dan penerbangan internasional dapat terselenggara secara terus menerus, langsung dan secepat mungkin serta tidak terhalang oleh perairan dan ruang udara teritorial Indonesia. ALKI ditetapkan untuk menghubungkan dua perairan bebas, yaitu 


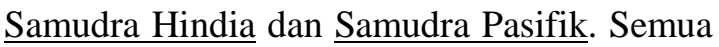
kapal dan pesawat udara asing yang mau melintas ke utara atau ke selatan harus melalui ALKI.

5. Masa Reformasi - Skr : Beberapa momen bersejarah bagi transportasi perdagangan Indonesia dan juga kelautan, diantaranya:

- Deklarasi Bunaken pada masa pemerintahan Presiden B.J. Habibie

- Departemen Eksplorasi Laut dibentuk pada masa pemerintahan Presiden Abdulrahman Wahid

- Dikeluarkannya seruan Sunda Kelapa pada masa pemerintahan Presiden Megawati

- Penyelenggaraan kegiatan World Ocean Conference oleh Dewan Kelautan pada masa pemerintahan Presiden Susilo Bambang Yudhoyono

- Pembangunan maritim dengan 5 pilar oleh Presiden Joko Widodo 


\section{SEJARAH PERKEMBANGAN TRANSPORTASI DAN PERDAGANGAN INTERNASIONAL DI INDONESIA}

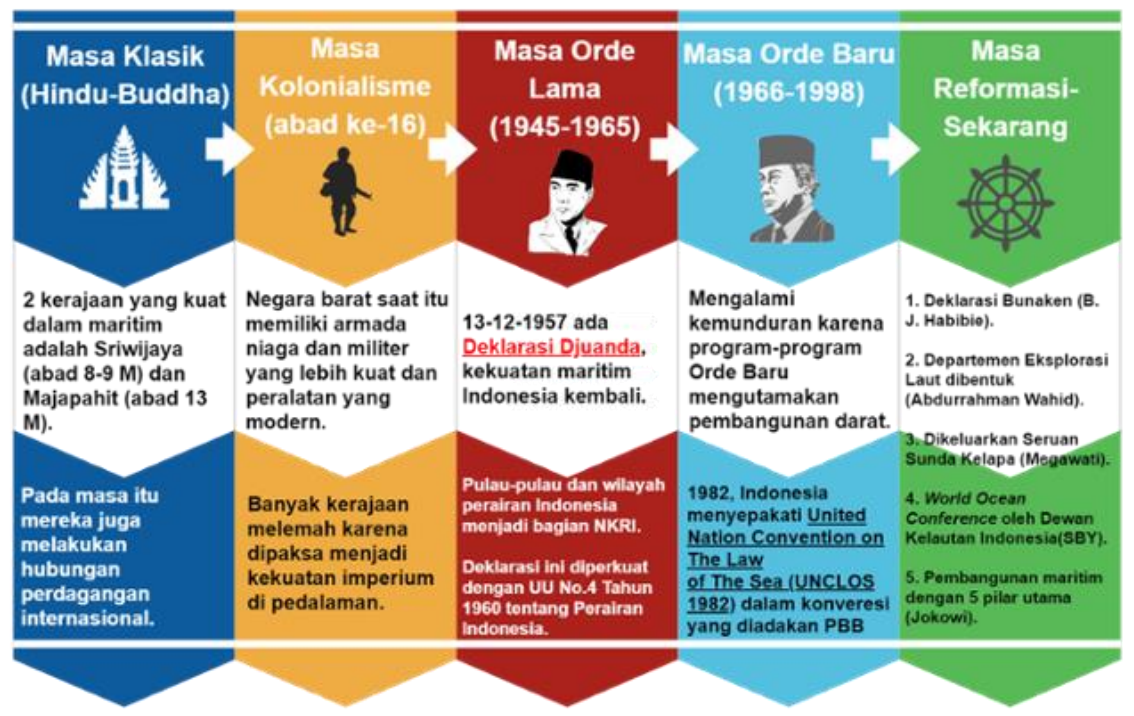

Gambar 16: Ilustrasi Sejarah Perkembangan Transportasi dan Perdagangan Internasional di Indonesia.

\section{World Trade Organization}

Perdagangan antarnegara merupakan bagian dari transaksi internasional. Ketentuan-ketentuan hukum yang mengatur hubungan tersebut menjadi bagian dari Hukum Ekonomi Internasional. Interaksi ekonomi internasional ini melahirkan perjanjian, yaitu:

a. Perjanjian Bilateral : Perjanjian antar 2 negara (contoh: kerjasama

b. Perjanjian Regional : Perjanjian negara-negara di dalam 1 kawasan (contoh: ASEAN)

c. Perjanjian Multilateral : Perjanjian lebih dari 2 negara di seluruh dunia (contoh: WTO)

Hubungan antar negara bukanlah hal yang mudah, terlebih lagi hubungan antar negara yang bersifat multilateral. Hubungan perdagangan antar negara muncul dari kebutuhan antar negara untuk mendistribusikan komoditi ekspor masing-masing negara. 
Hubungan dagang seringkali melibatkan kepentingan yang saling bertentangan. Perjanjian, termasuk yang dengan susah payah dinegosiasikan dalam sistem WTO, seringkali perlu ditafsirkan. Cara yang paling harmonis untuk menyelesaikan perbedaan-perbedaan ini adalah melalui beberapa prosedur netral berdasarkan landasan hukum yang disepakati. Itulah tujuan di balik proses penyelesaian sengketa yang ditulis dalam perjanjian WTO.(WTO, 1995)

WTO lahir dari negosiasi, dan semua yang dilakukan WTO adalah hasil negosiasi. Sebagian besar pekerjaan WTO saat ini berasal dari negosiasi 1986-1994 yang disebut Putaran Uruguay dan negosiasi sebelumnya di bawah General Agreement on Tariffs and Trade (GATT). WTO saat ini adalah tuan rumah bagi negosiasi baru, di bawah Doha Development Agenda yang diluncurkan pada tahun 2001.(WTO, 1995) Pembentukan organisasi ini dilatarbelakangi dengan berakhirnya Perang Dunia II. Perekonomian dunia yang hancur pada waktu itu, karena perang melibatkan negara-negara besar dunia seperti Amerika Serikat, negaranegara Eropa dan negara-negara dikawasan Asia seperti Jepang. Untuk menata kembali perekonomian dunia maka beberapa negara sepakat untuk membentuk lembaga perdagangan yang menjadi wadah yang berfungsi untuk mengatur perdagangan dunia yang menjadi penyokong bagi perekonomian dunia.(Kemendag, 2017) Pada prinsipnya WTO merupakan suatu sarana untuk mendorong terjadinya suatu perdagangan bebas yang tertib dan adil di dunia ini.(Oktaviano, 2017)

Tujuan dan fungsi WTO yaitu mendorong arus perdagangan antar negara melalui pengurangan tarif dan hambatan dalam perdagangan serta membatasi perlakukan diskriminasi dalam hubungan perdagangan internasional, yang kemudian tujuan tersebut tercermin dalam 5 fungsi WTO:(B. H. dan S. I. D. I. B. Indonesia, 2004)

1. Sebagai lembaga yang memberikan fasilitas implementasi, administrasi, dan pelaksanaan dari perjanjian plurilateral.

2. Sebagai lembaga yang menyediakan forum untuk melakukan perundingan di antara anggotanya terkait dengan isu yang diatur dalam perjanjian WTO termasuk menyediakan forum dan kerangka kerja untuk implementasi hasil-hasil perundingan yang telah dicapai. 
3. WTO bertindak selaku administrator dari aturan penyelesaian sengketa (Dispute Settlement Understanding).

4. WTO berfungsi selaku administrator mekanisme pengujian kebijakan perdagangan yang secara reguler melakukan peninjauan terhadap ketentuan perdagangan dari masing-masing negara anggota.

5. WTO bekerja sama dengan organisasi-organisasi internasional seperti International Monetary Fund (IMF) dan Bank Dunia (World Bank).

WTO dalam menjalankan tugas dan fungsinya, memiliki struktur organisasi yaitu:

1. Konferensi Tingkat Menteri: Dihadiri oleh perwakilan semua negara anggota WTO, konferensi ini melaksanakan fungsi-fungsi WTO dan juga memiliki wewenang untuk membuat keputusan yang berkaitan dengan perjanjian perdagangan multilateral.

2. General Council: Terdiri dari perwakilan semua anggota WTO, melaksanakan fungsi yang ditugaskan oleh perjanjian WTO yaitu menetapkan aturan dan prosedur perdagangan internasional.

3. Komite Perdagangan: Terdiri dari komite-komite perdagangan seperti komite untuk perdagangan barang (Council for Trade in Goods), komite perdagangan jasa (Council for Trade in Services), dan komite perdagangan yang berkaitan dengan Hak atas Kekayaan Intelektual (Council for Trade-Related Aspects of Intellectual Property Rights), dimana komite-komite ini bertanggung jawab dalam melakukan kegiatan yang diatur dalam perjanjian WTO Annex 1 (Multilateral Trade Agreements).(Soeparna, 2020) 


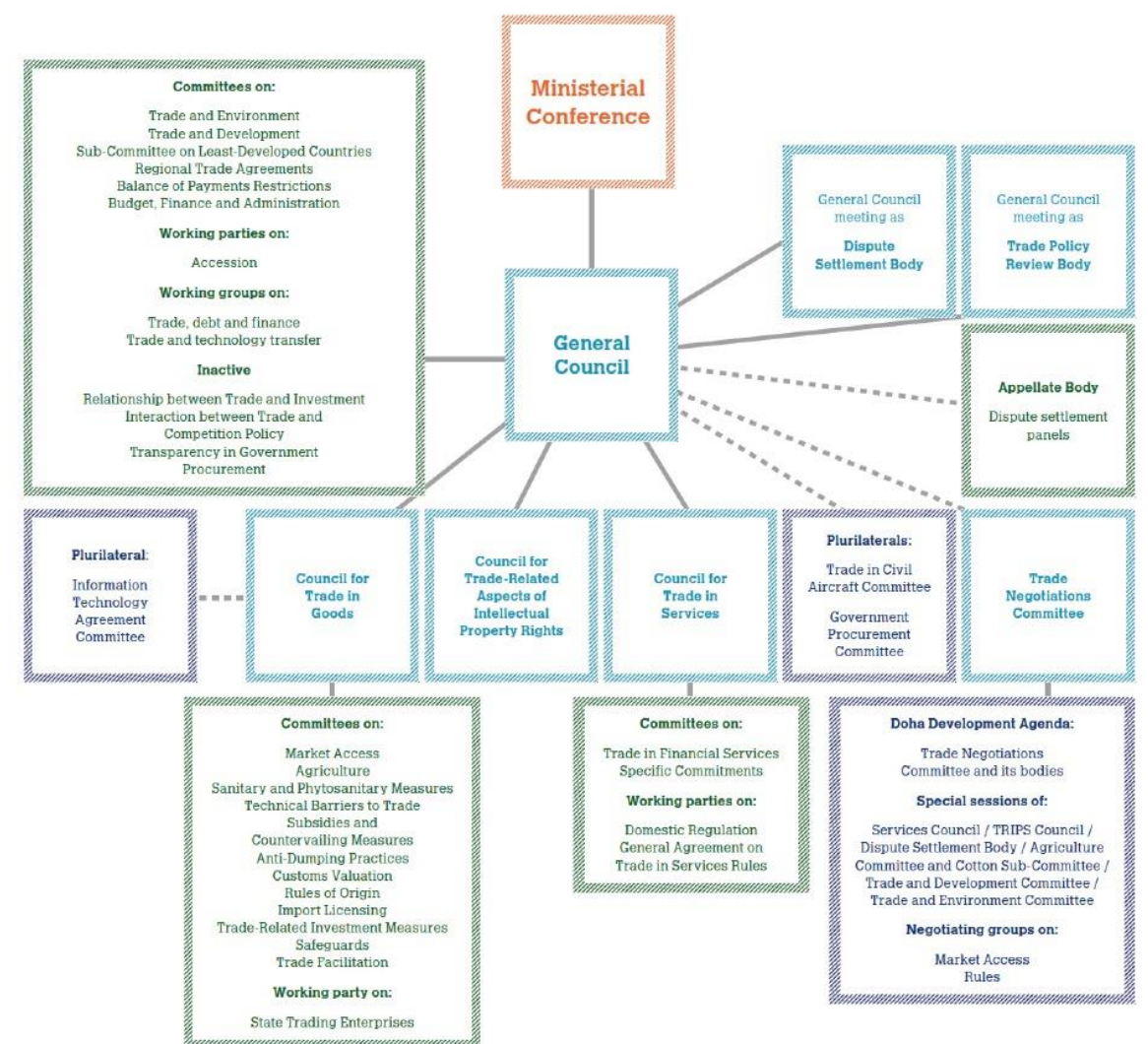

Gambar 17: Struktur Organisasi WTO. (WTO, 1995)

Pengambilan keputusan di WTO umumnya dilakukan berdasarkan konsensus oleh seluruh negara anggota. Badan tertinggi di WTO adalah Konferensi Tingkat Menteri (KTM) yang dilaksanakan setiap dua tahun sekali. Di antara KT, kegiatan-kegiatan pengambilan keputusan WTO dilakukan oleh General Council. Di bawahnya terdapat badan-badan subsider yang meliputi dewan, komite, dan sub-komite yang bertugas untuk melaksanakan dan mengawasi penerapan perjanjian-perjanjian WTO oleh negara anggota. (Kemlu, 2014)

Jumlah anggota WTO hingga saat ini adalah 164 negara dari seluruh dunia. Keanggotaan WTO terbuka untuk negara manapun, dengan syarat bahwa negara tersebut harus tunduk pada seluruh aturan WTO. Indonesia 
merupakan negara anggota WTO berdasarkan ratifikasi Agreement Establishing World Trade Organization (WTO Agreement) melalui undang-undang No.7 Tahun 1994. Dengan demikian Indonesia secara yuridis terikat untuk mengimplementasikan WTO Agreement tersebut, termasuk ketentuan-ketentuan Remidi Perdagangan, dalam hukum nasionalnya. Indonesia sebagai Negara anggota WTO diberikan kebebasan untuk membuat dan mengaplikasikan prosedur hukum nasionalnya sendiri yang secara otomatis harus konsisten dengan ketentuan-ketentuan WTO.(Oktaviano, 2017)

\section{Prinsip-prinsip Dasar dalam WTO}

Di dalam perkembangannya, WTO menyepakati prinsip-prinsip dasar yang menjadi dasar aturan main dalam perdagangan internasional: (Kemendag, 2017)

1. Perlakuan yang sama untuk semua anggota (Most Favoured Nations Treatment-MFN). Prinsip ini diatur dalam pasal I GATT 1994 yang mensyaratkan semua komitmen yang dibuat atau ditandatangani dalam rangka perlakuan yang secara kepada semua negara anggota WTO (azas non diskriminasi) tanpa syarat. Misalnya suatu negara tidak diperkenankan untuk menerapkan tingkat tarif yang berbeda kepada suatu negara dibandingkan dengan negara lainnya. Dengan berdasarkan prinsip MFN, negara-negara anggota tidak dapat begitu saja mendiskriminasikan mitra-mitra dagangnya. Keinginan tarif impor yang diberikan pada produk suatu negara harus diberikan pula kepada produk impor dari mitra dagang negara anggota lainnya.

2. Pengikatan Tarif (Tariff Binding). Prinsip ini diatur dalam pasal II GATT 1994 dimana setiap negara anggota GATT atau WTO harus memiliki daftar produk yang tingkat bea masuk atau tarifnya harus diikat (legally bound). Pengikatan atas tarif ini dimaksudkan untuk menciptakan "prediktabilitas" dalam urusan bisnis perdagangan internasional/ekspor. Artinya suatu negara anggota tidak diperkenankan untuk sewenang-wenang merubah atau menaikan tingkat tarif bea masuk.

3. Perlakuan nasional (National Treatment). Prinsip ini diatur dalam pasal III GATT 1994 yang mensyaratkan bahwa suatu negara tidak 
diperkenankan untuk memperlakukan secara diskriminasi antara produk impor dengan produk dalam negeri (produk yang sama) dengan tujuan untuk melakukan proteksi. Jenis-jenis tindakan yang dilarang berdasarkan ketentuan ini antara lain, pungutan dalam negeri, undangundang, peraturan dan persyaratan yang mempengaruhi penjualan, penawaran penjualan, pembelian, transportasi, distribusi atau penggunaan produk, pengaturan tentang jumlah yang mensyaratkan campuran, pemrosesan atau penggunaan produk-produk dalam negeri. Negara anggota diwajibkan untuk memberikan perlakuan sama atas barang-barang impor dan lokal- paling tidak setelah barang impor memasuki pasar domestik.

4. Perlindungan hanya melalui tarif. Prinsip ini diatur dalam pasal XI dan mensyaratkan bahwa perlindungan atas industri dalam negeri hanya diperkenankan melalui tarif.

5. Perlakuan khusus dan berbeda bagi negara-negara berkembang (Special Dan Differential Treatment For Developing Countries - S\&D). Untuk meningkatkan partisipasi nagara-negara berkembang dalam perundingan perdagangan internasional, S\&D ditetapkan menjadi salah satu prinsip GATT/WTO. Sehingga semua persetujuan WTO memiliki ketentuan yang mengatur perlakuan khusus dan berbeda bagi negara berkembang. Hal ini dimaksudkan untuk memberikan kemudahankemudahan bagi negara-negara berkembang anggota WTO untuk melaksanakan persetujuan WTO.

Sumber hukum pendukung yang terdapat pada aturan hukum WTO terdiri dari beberapa perjanjian internasional lainnya yang terdapat pada lampiran WTO Agreement, yaitu:

1. Perjanjian multilateral atas barang:(Peter Van Den Bosch, 2010)

A. General Agreement on Tariff and Trade 1994, GATT

B. Perjanjian khusus dalam perdagangan barang

- Agreement on Agriculture (Perjanjian dalam bidang pertanian)

- Agreement on the Application of Sanitary and Phytosanitary Measures (Perjanjian mengenai penerapan tindak sanitasi dan Phytosanitasi), SPS Agreement 
- Agreement on Technical Barriers to Trade (Perjanjian mengenai hambatan-hambatan teknis dalam perdagangan), TBT Agreement

- Agreement on Implementation of Article IV of the GATT (Perjanjian terkait tindakan Anti-Dumping), Anti-Dumping Agreement

- Agreement of Subsidies and Countervailing Measures (Perjanjian mengenai subsidi dan tindakan imbalan), SCM Agreement

- Agreement of Safeguards (Perjanjian mengenai Safeguards)

- General Agreement on Trade in Services (Perjanjian mengenai perdagangan di bidang jasa), GATS

2. Agreement on Trade-Related Aspects of Intellectual Property Rights (Perjanjian mengenai aspek-aspek yang berhubungan dengan Hak Kekayaan Intelektual), TRIPS Agreement

3. Perjanjian Mengenai Prosedur penyelesaian sengketa (Understanding on Rules and Procedures Governing the Settlement of Disputes)

4. Mekanisme penilaian kebijakan perdagangan (Trade Policy Review Mechanism), TRPM

5. Perjanjian Plurilateral mengenai pengadaan pemerintah (government procurement) dan perdagangan pesawat sipil (trade in civil aircraft)

Pada dasarnya WTO sebagai organisasi yang mewadahi perdagangan antar negara dengan berbagai kesepakatan di dalamnya. WTO mempersilahkan setiap anggota untuk mengajukan keberatan ketika hak dari negara tersebut terganggu atau apabila suatu negara anggota merasa negara lain telah dengan sengaja ataupun tidak melanggar kesepakatan yang telah ditetapkan bersama dalam WTO.

Manfaat WTO bagi Negara berkembang adalah dapat meningkatkan kinerja, khususnya bagi Indonesia dapat menjamin terciptanya lapangan pekerjaan, meningkatkan produksi dan perdagangan dan mengoptimalkan pemanfaatan sumber daya dunia. Sementara itu terdapat hambatan, antara lain kurangnya komitmen pemerintah dalam meningkatkan dunia usaha akibat mengalami masalah dalam pembangunan, ditambah dengan kurangnya kesiapan sumber daya manusia, baik pengusaha, kalangan 
professional, maupun pejabat pemerintah. Untuk itu, perlu harmonisasi dan sinkronisasi peraturan perundang-undangan, baik yang bersifat nasional maupun internasional dengan tetap mengutamakan kepentingan nasional. (Jamilus, 2017)

\section{TANTANGAN PERDAGANGAN INTERNASIONAL}

Salah satu tantangan bagi perdagangan internasional adalah persaingan dengan produk kompetitor negara lain. Perlu dilakukan antara lain peningkatan daya saing dan diversifikasi produk ke arah yang lebih banyak meningkatkan nilai tambah, umumnya produk manufaktur sehingga dapat meningkatkan nilai produk dan penyerapan tenaga kerja. Selain itu liberalisasi perdagangan yang terjadi saat ini berpotensi mematikan industri dalam negeri. Hal ini disebabkan selama ini industri dalam negeri tidak dilatih untuk berkompetisi secara sehat atau tidak ditumbuhkan budaya bersaing. Permasalahan yang tidak kalah penting untuk diatasi adalah perlu sinkronisasi kebijakan pemetaan industri (road map) yang sejalan dengan pemetaan potensi ekspor sehingga saling mengisi dan jelas penahapannya. Dengan demikian kinerja ekspor akan sangat terkait erat dengan kinerja industri tersebut di dalam negeri.(T. B. Indonesia, 2007)

Menteri Perdagangan, Agus Suparmanto, mengungkapkan, setidaknya terdapat empat tantangan utama dalam perdagangan global di masa pandemi Covid-19 saat ini. Pelaku usaha wajib bisa menyiasati tantangan itu agar tetap bisa menjamah pasar yang saat ini tengah melemah. Agus mengatakan, tantangan pertama yakni perubahan perilaku konsumen dan pola perdagangan global. Konsumen saat ini jauh lebih selektif khususnya untuk produk makanan dan minuman. Food safety dan higienitas menjadi prioritas sekaligus transaksi perdagangan secara online.Tantangan kedua yakni sikap proteksionisme perdagangan. Kebijakan itu akan meningkatkan hambatan perdagangan baik dari sisi hambatan tarif maupun nontarif.

Salah satu bentuk proteksionisme anti-dumping, subsidy safeguards, circumvention, serta anti-fraud. Selain itu, isu lingkungan dan isu keberlanjutan alam juga kerap dijadikan sebagai dalih untuk bisa melakukan proteksionisme. Tantangan selanjutnya yakni sulitnya kerja 
sama perdagangan antar negara di dunia. Akibat pandemi Covid-19, perundingan kerja sama menjadi sulit diselesaikan. Karena itu, pemerintah Indonesia bersama pengusaha disarankan untuk fokus meningkatkan implementasi perjanjian-perjanjian dagang yang sudah disepakati. Tantangan terakhir yang dihadapi secara nyata saat ini yakni potensi defisit dan resesi ekonomi. Hal ini tidak lain merupakan dampak dari Covid-19. "Perang dagang China-AS, China-Uni Eropa, Jepang-Korea Selatan, China-Hong Kong turut menghambat perdagangan. Protes Uni Eropa dan AS ke Turki terkait konversi Haghia Sophia juga berpengaruh. (Republika.co.id, 2020)

UMKM memiliki potensi dan kemampuan dalam mengelola sumber daya manusia terutama pada 5 sektor utama; UMKM mendominasi pada sektor pertanian jasa, hotel dan restaurant. Keterbatasan kualitas dan standarisasi jasa pelayanan dan informasi, kualitas SDM dan teknologi serta kultural berpengaruh pada pengelolaan, eksploitasi sumberdaya dan pengembangan disain produk yang inovatif. Kendala yang dihadapi UKM untuk menghadapi pasar global perlu penggunaan teknologi, media informasi dan komunikasi, internet yang menembus pasar ekspor, karena hambatan pada bidang budaya, komunikasi, aturan regulasi serta tingkat ekonomi daya beli masyarakat.(Tamjuddin, n.d.)

Menteri Pariwisata dan Ekonomi Kreatif (Menparekraf) Wishnutama Kusubandio mengungkapkan sejumlah tantangan harus dihadapi pelaku Usaha Mikro Kecil dan Menegah (UMKM) sektor kreatif untuk memasuki pasar global. Terkait logistik, dokumen dan administrasi, biaya ekspor tinggi karena kebanyakan pelaku ekonomi kreatif masih didominasi UMKM yang tidak semua paham proses ekspor. Tantangan lain yang didapatkan berdasarkan hasil diskusi dengan pelaku ekonomi kreatif yakni UMKM sektor kreatif bukan memproduksi produk massal sehingga kemampuan produksi masih kecil. Selain itu kurangnya mesin produksi, kesulitan informasi pasar terutama terkait pasar potensial untuk produknya, dan kurang berani dalam menjajaki pasar ekspor. Kurang kemampuan pemasaran digital, kurang platform e-commerce untuk ekspor dan konsekuensi biaya tinggi, pelaku UMKM juga masih banyak dihadapkan dengan prasyarat dan sertifikasi yang rumit dan mahal, regulasi perizinan yang harus bisa disederhanakan misalnya perizinan ekspor termasuk biaya 
masuk di negara tujuan. Ketika diberlakukan Pembatasan Sosial Berskala Besar (PSBB) untuk menekan penyebaran COVID-19, banyak pelaku kreatif mendapatkan kesulitan terkait bahan baku karena banyak bahan baku dasar perlu impor luar negeri. PSBB membuat distribusi logistik terganggu yang membuat barang kiriman yang dibeli menjadi lebih lama. Saat PSBB, lanjut dia, pendapatan pelaku kreatif menurun karena tidak ada konsumen yang membeli dan mereka mengalami kesulitan dalam pinjaman modal. Untuk menjawab tantangan itu, Kemenparekraf memiliki program yang mengikutsertakan UMKM terpilih untuk ikut promosi daring di luar negeri dan membuat direktori khusus untuk produk kreatif disebarkan di seluruh perwakilan Indonesia di luar negeri.

Kerja sama dengan pemangku kebijakan terkait untuk memberikan bantuan stimulus dan pinjaman modal kepada pelaku kreatif juga dilakukan termasuk mengajak masyarakat mencintai dan bangga produk dalam negeri serta kerja sama dengan marketplace. Pandemi COVID-19 diharapkan menjadi momentum industri kreatif mengakselerasi digitalisasi dengan memanfaatkan platform e-commerce. Berdasarkan data Kementerian Koperasi dan UKM, jumlah pelaku UMKM tahun 2018 mencapai sekitar 64 juta. Namun, baru sekitar 13 persen atau sekitar delapan juta di antaranya yang sudah digital. (Inditourist, 2020)

Prioritas dalam strategi pasar global, dilakukan dengan pemasaran online, peningkatan ekspor yang optimal maka diperlukan pengembangan merk yang akan meningkatkan minat pembeli produk nasional, melalui upaya Kemendag dan Industri ekonomi kreatif, sejak 2011-2012, promosi produk UKM sudah dikenalkan berbagai merk produk nasional, forum pemasaran produk dilakukan oleh Kadin, Asean-China Free Trade Agreement (ACFTA) pengembangan produk ekspor ke kawasan Asia yang berkapasitas product massal dan customize Strategi pemasaran diperlukan untuk produk ekspor, orientasi produk dan service, lisensi, jalinan kerjasama dan usaha baru, lemahnya persyaratan dan kriteria jenis usaha yang dikembangkan UKM yang memiliki potensi dan berorientasi pada Creating Value.(Tamjuddin, n.d.) 


\section{DAFTAR PUSTAKA}

Abdurohim, D. (2020). Strategi Pengembangan Kelembagaan UMKM

(Cetakan Pe). Bintang Pustaka Madani.

Agung, J. M. (2017). PENERAPAN ASAS FIKSI HUKUM DALAM

PERMA. 31 Agustus 2017.

https://jdih.mahkamahagung.go.id/index.php/beranda/kegiatan/9-

kegiatan/139-penerapan-asas-fiksi-hukum-dalam-

perma\#: :text=Asas Fiksi Hukum beranggapan bahwa, membebaskan\%2Fmemaafkannya dari tuntutan hukum

Alam, M. A. A. \& S. N. (2020). E-Commerce: Dasar Teori Dalam Bisnis Digital (J. H. \& J. Simarmata (Ed.)). Yayasan Kita Menulis.

Allianz. (2014). How The Panama Canal Was Built. 13 Agustus 2014. https://www.allianz.com/en/press/extra/knowledge/mobility/14081 3-how-the-panama-canal-was-built.html

Basri, F. (2003). Dinamika UKM di Antara Gemuruh Retorika Politik dan

Mitos. Seminar Pembangunan Hukum Nasional VIII.

Bocweb.id. (2017). Roadmap E-Commerce.

https://www.boc.web.id/roadmap-e-commerce-indonesia-20172019/

Bratton, B. H. (2015). The Stack: On Software and Soverreignty.

Massachusetts Institute of Technology.

Cannon, Joseph P; Perreault, William D; McCarthy, J. E. J. (2008).

Pemasaran Dasar: Pendekatan Manajerial Global (Basic

Marketing: A Global-Managerial Approach) (Edisi 16). Salemba

Empat.

Doktorhukum. (2019). Pengertian dan Kedudukan Perjanjian/Kontrak

Elektronik. 26 Juli 2019.

Encyclopedia, A. H. (2018). Silk Road. 1 Mei 2018.

https://www.ancient.eu/Silk_Road/

Firmansyah, M. A. (2019). Pemasaran: Dasar dan Konsep. CV. Penerbit Qiara Media. 
Fuady, M. (2012). Pengantar Hukum Bisnis: Menata Bisnis Modern di Era Global. Citra Aditya Bakti.

Gilarso, T. (2003). Pengantar Ilmu Ekonomi Mikro. Kanisius.

Greenhouse. (2019). Indonesia's Digital Economy: Growth Prospects After 2020. https://greenhouse.co/blog/indonesia-digital-economyprospects-after-2020/

Highligth Pertukaran cloth and food. (n.d.).

https://www.youtube.com/watch?v=2isPkhtCcbM\%0D\%0AHighli gth Pertukaran cloth and food\%0D\%0A

Hotels.com. (n.d.). Ubud Art Market in Bali Traditional Market and Shopping Destination in Ubud.

I Putu Gede Budayasa, I Gede Totok Suryawan, Ni Putu Suci Meinarni, W. E. M. \& K. R. W. (2018). Seller's Rights and Obligations of Marketplace in Indonesia. Proceeding: International Conference on Innovation in Research 2018, Section: Economic \& Management Science.

Inditourist. (2020). Ini hambatan UMKM masuk pasar global. 29 Agustus 2020.

Indonesia, B. H. dan S. I. D. I. B. (2004). Kerjasama Perdagangan Internasional Peluang dan Tantangan bagi Indonesia. PT Elex Media Komputindo.

Undang-undang Perlindungan Konsumen, (1999).

Undang-Undang Republik Indonesia Nomor 28 Tahun 2007 tentang Perubahan Ketiga Atas Undang-Undang Nomor 6 Tahun 1983 tentang Ketentuan Umum Dan Tata Cara Perpajakan, (2007).

UU Informasi dan Transaksi Elektronik, Pub. L. No. Undang-Undang Nomor 19 Tahun 2016 perubahan atas Undang-Undang Nomor 11 Tahun 2008 (2016).

Peraturan Pemerintah Republik Indonesia Nomor 24 Tahun 2018 tentang Pelayanan Perizinan Berusaha Terintegrasi Secara Elektronik, (2018).

Indonesia, T. B. (2007). Kerjasama Perdagangan Internasional: Peluang dan Tantangan Bagi Indonesia. PT Elex Media Komputindo.

Indonesia, V. (2020). Tips Membuat Terms and Conditions Yang Baik Untuk Toko Online Anda. 
Indonesiabaik.id. (2017). Peta Jalan E-Commerce 2017-2019.

http://indonesiabaik.id/infografis/peta-jalan-e-commerce-20172019

Infoperbankan. (2018). Daftar Bank Penyalur KUR.

https://www.infoperbankan.com/umum/daftar-bank-penyalur-kurkredit-usaha-rakyat.html

Jamilus. (2017). ANALISIS FUNGSI DAN MANFAAT WTO BAGI NEGARA BERKEMBANG ( KHUSUSNYA INDONESIA ) ( Analysis Of The Function And Benefits Of WTO For Developing Countries ( Especially Indonesia )) Abstrak. Jikh, 11(2), 205-225.

Jonaedi Efendi, I. G. W. \& F. F. L. (2016). Kamus Istilah Hukum Populer (Edisi Pert). Prenadamedia.

Kamusbesar. (n.d.). Terms and Conditions. https://www.kamusbesar.com/terms-and-condition

Kemendag, P. (2017). World Trade Organization (WTO). 4 Desember 2017. http://pusdiklat.kemendag.go.id/v2019/article/world-tradeorganization-wto\#: :text=Sejarah World Trade Organization\&text=WTO adalah organisasi antar pemerintah,dengan berakhirnya Perang Dunia II.

Kemlu. (2014). World Trade Organization (WTO). 8 Juni 2014. https://kemlu.go.id/portal/id/read/133/halaman_list_lainnya/worldtrade-organization-wto

Kominfo. (2016). SIARAN PERS NO.45/HM/KOMINFO/06/2016, Gerakan Nasional 1000 Startup Digital: Gotong Royong Wujudkan Solusi di Era Informasi. https://kominfo.go.id/index.php/content/detail/7684/siaran-persno45hmkominfo062016-tentang-gerakan-nasional-1000-startupdigital-gotong-royong-wujudkan-solusi-di-erainformasi/0/siaran_pers

Kusuma, D. C. (2018). Menjadi Kaya Di Bisnis E-Commerce (Rahasia Mendapatkan 1 Miliar Rupiah dalam 100 Hari) (6th ed.). PT Gramedia Pustaka Utama.

Laila, S. M. \& K. (2018). Hukum Bisnis. Polinema Press. Lalamove. (2020). Mengapa UMKM Penting bagi Perekonomian? Ini 4 Alasannya. 26 Juni 2020. 
https://www.lalamove.com/indonesia/jakarta/id/blog/4-alasanbisnis-umkm-penting\#: :text=Ada alasan kenapa UMKM disebut,punggung dari ekonomi yang sehat.\&text=Sederhananya\%2C UMKM memiliki peran signifikan,dan menciptakan pasar yang seimbang.

Liputan6.com. (2020). Pasar Dalam Negeri Masih Potensial, UMKM Tinggal Optimalkan Sederet Peluang. 8 September 2020.

M. Fuad, Christine H, Nurlela, S. dan P. Y. E. . (2000). Pengantar Bisnis. PT. Gramedia Pustaka Utama.

M, I. P. \& J. (2016). Analisis Faktor-faktor yang memengaruhi Penggunaan Jasa Pengiriman JNE (Studi Kasus Masyarakat yang Tinggal di Kota Bogor).

Makalah.id. (2017). Contoh Makalah E-Commerce Pasar Digital dan Barang Digital. https://www.makalah.id/contoh-makalah-ecommerce-pasar-digital-dan-barang-digital/

Markey. (2019). Pemasaran Konvensional Paling Efektif $\mid$ Strategi

Marketing. https://markey.id/blog/marketing/pemasarankonvensional\#: :text=Pemasaran Konvensional adalah salah satu,muka dan begitu pula sebaliknya.

Maros, K. P. (2017). Pendaftaran NPWP untuk badan tidak susah. 30 September 2017. https://kpppratamamaros.com/2017/09/30/pendaftaran-npwpuntuk-badan-tidak-susah/

Maxmanroe. (n.d.). Arti MoU (Memorandum of Understanding): Pengertian, Tujuan, Manfaat, dan Jenisnya. https://www.maxmanroe.com/vid/bisnis/arti-mou.html

Musfar, T. F. (2020). Buku Ajar Manajemen Pemasaran: Bauran Pemasaran sebagai Materi Pokok dalam Manajemen Pemasaran. CV. Media Sains Indonesia.

Mustofa, E. (2011). TANGGUNG JAWAB PENGANGKUT TERHADAP BARANG BAGASI DALAM PENGANGKUTAN DARAT [Universitas Airlangga]. http://repository.unair.ac.id/11271/ Nasution, K. (2014). PENERAPAN PRINSIP TANGGUNG JAWAB PENGANGKUT TERHADAP PENUMPANG BUS UMUM. Mimbar Hukum UGM, 26(1), 54-69. 
Nizar, N. I. (2017). Analisis Model Bisnis Dan Strategi Perusahaan Start Up E-Commerce: Studi Kasus Pada Gerobakonline .Com. Jurnal Mandiri, 1(1).

Oktaviano, A. (2017). Peran World Trade Organization (Wto) Dalam Menyelesaikan Sengketa Perdagangan Daging Sapi Antara Amerika-Indonesia Tahun 2012-2016. Jom FISIP Bina Widya, $4(2)$.

Pajak, D. (2018). Pajak UMKM/UMKM: Apa Saja Pajak yang Harus Dibayarkan?

Peter Van Den Bosch, D. N. \& J. W. K. (2010). Pengantar Hukum WTO

(World Trade Organization). Yayasan Pustaka Obor Indonesia.

Prayogo, A. (2014). ASAS DALAM HUKUM PENGANGKUTAN. 9 Maret 2014.

Purwanti, E. (2012). Pengaruh Karakteristik Wirausaha, Modal Usaha, Strategi Pemasaran Terhadap Perkembangan Umkm Di Desa Dayaan Dan Kalilondo Salatiga. Among Makarti, 5(9).

Rangkuti, F. (2017). Customer Care Excellence: Meningkatkan Kinerja Perusahaan Melalui Pelayanan Prima Plus Analisis Kasus Jasa RaharjaNo Title. PT Gramedia Pustaka Utama.

Republika.co.id. (2020). Ini Empat Tantangan Perdagangan Global Menurut Mendag. 22 Juli 2020. https://republika.co.id/berita/qdv9nb457/ini-empat-tantanganperdagangan-global-menurut-mendag

Rijanto, Ahmad; Rahayuningsih, S. (2020). Pelatihan \& Pendampingan Usaha Mikro Kerupuk Samiler. Uwais Inspirasi Indonesia.

RM, P. (2017). Cara Laris Jualan Kuliner via Media Sosial. Laksana. Romindo; Muttaqin; Saputra, Didin Hadi; Purba, Deddy Wahyudin; Iswahyudi, M.; Banjarnahor, Astri Rumondang; Kusuma, Aditya Halim Perdana; Faried, Effendi; Sulaiman, Oris Kristianto; Simarmata, J. (2019). E-Commerce: Implementasi, Strategi \& Inovasinya. Yayasan Kita Menulis.

Roosdiyana, F. (2010). Keabsahan Kontrak Elektronik Dalam Penyelenggaraan Transaksi Elektronik [Universitas Islam Indonesia]. https://law.uii.ac.id/wp-content/uploads/2013/01/FHUII-KEABSAHAN-KONTRAK-ELEKTRONIK-DALAM- 
PENYELENGGARAAN-TRANSAKSI-ELEKTRONIK.pdf

Rumondang, Astri; Sudirman, Acai; Sitorus, Samsider; Kusuma, Aditya

Halim Perdana; Manuhutu, Melda; Sudarso, Andriansan;

Simarmata, Janner; Tasnim, Dian Hasdiana; Arif, N. F. (2020).

Pemasaran Digital dan Perilaku Konsumen (A. Rikki (Ed.)).

Yayasan Kita Menulis.

Sakti, N. W. (2014). Buku Pintar Pajak E-commerce Dari Mendaftar

Sampai Membayar Pajak. Visimedia.

Sari, Anggri Puspita; Anggraini, Dina Dewi; Sari, Marlynda Happy

Nurmalita; Gandasari, Dyah; Siagian, Valentine; Septarini, Ri

Sabti; Tjiptadi, Diena Dwidienawati; Sulaiman, Oris Krianto;

Munsarif, Muhammad; Siregar, Prima Andreas; Nugraha, Nur

Arif; Sima, J. (2020). Kewirausahaan Bisnis Online. Yayasan Kita

Menulis.

Sarno Wuragil. (2017). Jenis-jenis Perjanjian dalam Bisnis. 22 Januari 2017.

Sarwono, Jonathan; Prihartono, K. (2012). Perdagangan Online: Cara

Bisnis di Internet. PT Elex Media Komputindo.

Sciencetechnologyandhealth.wordp. (2016). a brief history of international trade routes. 26 April 2016.

https://sciencetechnologyandhealth.wordpress.com/2016/04/26/a-

brief-history-of-international-trade-routes/

Semesta, S. (2020). Kelebihan Serta Kekurangan dari Pemasaran

Tradisional dan Pemasaran Online.

https://suryasemesta.com/kelebihan-serta-kekurangan-dari-

pemasaran-tradisional-dan-pemasaran-online.html

Sidabalok, J. (2020). Hukum Perdagangan (Perdagangan Nasional dan

Internasional). Yayasan Kita Menulis.

Soeparna, I. I. (2020). Hukum Perdagangan Internasional dalam World

Trade Organization. Airlangga University Press.

Sumadi, P. S. (2019). Hukum Dagang Intern-Nasional. Zifatama Jawara.

Supriatna, Yuda; Adiyanto, Yoga; Sunaryo, D. (2019). Induksi Manajemen

Pemasaran. CV. Penerbit Qiara Media.

Suwardi. (2015). Hukum Dagang Suatu Pengantar. Deepublish.

Suyanto, M. (2003). Strategi Periklanan Pada E-Commerce Perusahaan 
Top Dunia. Penerbit Andi.

Syahputro, E. N. (2020). Melejitkan Pemasaran UMKM Melalui Media Sosial. Caremedia Communication Gresik.

Tambunan, Toman Sony; Tambunan, W. R. . (2019). Hukum Bisnis.

Prenada Media Group.

Tamjuddin. (n.d.). KAPASITAS UMKM MENGHADAPI PASAR

GLOBAL. Semnas Fekon: Optimisme Ekonomi Indonesia 2013, Antara Peluang Dan Tantangan.

http://repository.ut.ac.id/5101/1/fekon2012-59.pdf

Tirto.id. (2019). Sejarah Uang dalam Peradaban Manusia: Dari Barter Hingga Bitcoin. 19 Oktober 2019. https://tirto.id/sejarah-uangdalam-peradaban-manusia-dari-barter-hingga-bitcoin-ejXX

Tribunnews. (2018). Wajib Pajak Bakal Diperiksa Ditjen Pajak Kalau Lakukan Ini. 23 April 2018.

Tripadvisor. (n.d.). Trip Advisor Logo. Retrieved April 5, 2019, from https://www.tripadvisor.com/LocationPhotoDirectLink-g34515d9728180-i169200603-Tharoo_Co-Orlando_Florida.html

Wearesocial. (2018). The State of the Internet in Q4 2018. https://wearesocial.com/blog/2018/10/the-state-of-the-internet-inq4-2018

Wikipedia. (2019). Terusan Panama. https://id.wikipedia.org/wiki/Terusan_Panama

Wikipedia. (2020). Hukum dagang. 26 November 2020.

WTO. (1995). About WTO. https://www.wto.org/english/thewto_e/thewto_e.htm

YLKI. (2017). Yayasan Lembaga Konsumen Indonesia. https://ylki.or.id/hak-konsumen/

Yogos-Shelter. (2014). Surat Keterangan Domisili Usaha (SKDU). http://yogos-shelter.blogspot.com/p/surat-izin-domisili.html\#.W509ZMzZE42. 


\section{LAMPIRAN}

\section{UNDANG-UNDANG REPUBLIK INDONESIA NOMOR 20 TAHUN 2008 TENTANG USAHA MIKRO, KECIL DAN MENENGAH DENGAN RAHMAT TUHAN YANG MAHA ESA PRESIDEN REPUBLIK INDONESIA,}

Menimbang:

a. Bahwa masyarakat adil dan makmur berdasarkan Pancasila dan Undang-Undang Dasar Negara Republik Indonesia Tahun 1945 harus diwujudkan melalui pembangunan perekonomian nasional berdasarkan demokrasi ekonomi;

b. Bahwa sesuai dengan amanat Ketetapan Majelis Permusyawaratan Rakyat Republik Indonesia Nomor XVI/MPR-RI/1998 tentang Politik Ekonomi dalam rangka Demokrasi Ekonomi, Usaha Mikro, Kecil, dan Menengah perlu diberdayakan sebagai bagian integral ekonomi rakyat yang mempunyai kedudukan, peran, dan potensi strategis untuk mewujudkan struktur perekonomian nasional yang makin seimbang, berkembang, dan berkeadilan;

c. Bahwa pemberdayaan Usaha Mikro, Kecil, dan Menengah sebagaimana dimaksud dalam huruf $b$, perlu diselenggarakan secara menyeluruh, optimal, dan berkesinambungan melalui pengembangan iklim yang kondusif, pemberian kesempatan berusaha, dukungan, perlindungan, dan pengembangan usaha seluasluasnya, sehingga mampu meningkatkan kedudukan, peran, dan potensi Usaha Mikro, Kecil, dan Menengah dalam mewujudkan pertumbuhan ekonomi, pemerataan dan peningkatan pendapatan rakyat, penciptaan lapangan kerja, dan pengentasan kemiskinan;

d. Bahwa sehubungan dengan perkembangan lingkungan perekonomian yang semakin dinamis dan global, Undang- Undang Nomor 9 Tahun 1995 tentang Usaha Kecil, yang hanya mengatur Usaha Kecil perlu diganti, agar Usaha Mikro, Kecil, dan Menengah di Indonesia dapat memperoleh jaminan kepastian dan keadilan usaha; 
e. Bahwa berdasarkan pertimbangan sebagaimana dimaksud dalam huruf $a$, huruf $b$, huruf $c$, dan huruf d, perlu membentuk UndangUndang tentang Usaha Mikro, Kecil, dan Menengah.

Mengingat:

Pasal 5 ayat (1), Pasal 20, Pasal 27 ayat (2), dan Pasal 33 UndangUndang Dasar Negara Republik Indonesia Tahun 1945.

\section{MEMUTUSKAN:}

Menetapkan:

UNDANG-UNDANG TENTANG USAHA MIKRO, KECIL, DAN MENENGAH

\section{BAB I \\ KETENTUAN UMUM \\ Pasal 1}

Dalam Undang-Undang ini yang dimaksud dengan:

1. Usaha Mikro adalah usaha produktif milik orang perorangan dan/atau badan usaha perorangan yang memenuhi kriteria Usaha Mikro sebagaimana diatur dalam Undang-Undang ini.

2. Usaha Kecil adalah usaha ekonomi produktif yang berdiri sendiri, yang dilakukan oleh orang perorangan atau badan usaha yang bukan merupakan anak perusahaan atau bukan cabang perusahaan yang dimiliki, dikuasai, atau menjadi bagian baik langsung maupun tidak langsung dari Usaha Menengah atau Usaha Besar yang memenuhi kriteria Usaha Kecil sebagaimana dimaksud dalam Undang-Undang ini.

3. Usaha Menengah adalah usaha ekonomi produktif yang berdiri sendiri, yang dilakukan oleh orang perorangan atau badan usaha yang bukan merupakan anak perusahaan atau cabang perusahaan yang dimiliki, dikuasai, atau menjadi bagian baik langsung maupun tidak langsung dengan Usaha Kecil atau Usaha Besar dengan jumlah kekayaan bersih atau hasil penjualan tahunan sebagaimana diatur dalam Undang- Undang ini. 
4. Usaha Besar adalah usaha ekonomi produktif yang dilakukan oleh badan usaha dengan jumlah kekayaan bersih atau hasil penjualan tahunan lebih besar dari Usaha Menengah, yang meliputi usaha nasional milik negara atau swasta, usaha patungan, dan usaha asing yang melakukan kegiatan ekonomi di Indonesia.

5. Dunia Usaha adalah Usaha Mikro, Usaha Kecil, Usaha Menengah, dan Usaha Besar yang melakukan kegiatan ekonomi di Indonesia dan berdomisili di Indonesia.

6. Pemerintah Pusat, selanjutnya disebut Pemerintah, adalah Presiden Republik Indonesia yang memegang kekuasaan pemerintahan Negara Republik Indonesia sebagaimana dimaksud dalam Undang-Undang Dasar Negara Republik Indonesia Tahun 1945.

7. Pemerintah Daerah adalah Gubernur, Bupati, atau Walikota, dan perangkat daerah sebagai unsur penyelenggara pemerintahan daerah.

8. Pemberdayaan adalah upaya yang dilakukan Pemerintah, Pemerintah Daerah, Dunia Usaha, dan masyarakat secara sinergis dalam bentuk penumbuhan iklim dan pengembangan usaha terhadap Usaha Mikro, Kecil, dan Menengah sehingga mampu tumbuh dan berkembang menjadi usaha yang tangguh dan mandiri.

9. Iklim Usaha adalah kondisi yang diupayakan Pemerintah dan Pemerintah Daerah untuk memberdayakan Usaha Mikro, Kecil, dan Menengah secara sinergis melalui penetapan berbagai peraturan perundangundangan dan kebijakan di berbagai aspek kehidupan ekonomi agar Usaha Mikro, Kecil, dan Menengah memperoleh pemihakan, kepastian, kesempatan, perlindungan, dan dukungan berusaha yang seluasluasnya.

10. Pengembangan adalah upaya yang dilakukan oleh Pemerintah, Pemerintah Daerah, Dunia Usaha, dan masyarakat untuk memberdayakan Usaha Mikro, Kecil, dan Menengah melalui pemberian fasilitas, bimbingan, pendampingan, dan bantuan perkuatan untuk menumbuhkan dan meningkatkan kemampuan dan daya saing Usaha Mikro, Kecil, dan Menengah. 
11. Pembiayaan adalah penyediaan dana oleh Pemerintah, Pemerintah Daerah, Dunia Usaha, dan masyarakat melalui bank, koperasi, dan lembaga keuangan bukan bank, untuk mengembangkan dan memperkuat permodalan Usaha Mikro, Kecil, dan Menengah.

12. Penjaminan adalah pemberian jaminan pinjaman Usaha Mikro, Kecil, dan Menengah oleh Lembaga penjamin kredit sebagai dukungan untuk memperbesar kesempatan memperoleh pinjaman dalam rangka memperkuat permodalannya.

13. Kemitraan adalah kerjasama dalam keterkaitan usaha, baik langsung maupun tidak langsung, atas dasar prinsip saling memerlukan, mempercayai, memperkuat, dan menguntungkan yang melibatkan pelaku Usaha Mikro, Kecil, dan Menengah dengan Usaha Besar.

14. Menteri adalah menteri yang tugas dan tanggung jawabnya di bidang Usaha Mikro, Kecil, dan Menengah.

15. Menteri Teknis adalah menteri yang secara teknis bertanggung jawab untuk mengembangkan Usaha Mikro, Kecil, dan Menengah dalam sektor kegiatannya.

\section{BAB II \\ ASAS DAN TUJUAN}

Pasal 2

Usaha Mikro, Kecil, dan Menengah berasaskan:
a. Kekeluargaan;
b. Demokrasi ekonomi;
c. Kebersamaan;
d. Efisiensi berkeadilan;
e. Berkelanjutan;
f. Berwawasan lingkungan;
g. Kemandirian;
h. Keseimbangan kemajuan; dan
i. Kesatuan ekonomi nasional. 
Pasal 3

Usaha Mikro, Kecil, dan Menengah bertujuan menumbuhkan dan mengembangkan usahanya dalam rangka membangun perekonomian nasional berdasarkan demokrasi ekonomi yang berkeadilan.

\author{
BAB III \\ PRINSIP DAN TUJUAN PEMBERDAYAAN \\ Bagian Kesatu \\ Prinsip Pemberdayaan \\ Pasal 4
}

Prinsip pemberdayaan Usaha Mikro, Kecil, dan Menengah:

a. Penumbuhan kemandirian, kebersamaan, dan kewirausahaan Usaha Mikro, Kecil, dan Menengah untuk berkarya dengan prakarsa sendiri;

b. Perwujudan kebijakan publik yang transparan, akuntabel, dan berkeadilan;

c. Pengembangan usaha berbasis potensi daerah dan berorientasi pasar sesuai dengan kompetensi Usaha Mikro, Kecil, dan Menengah;

d. Peningkatan daya saing Usaha Mikro, Kecil, dan Menengah; dan

e. Penyelenggaraan perencanaan, pelaksanaan, dan pengendalian secara terpadu.

\title{
Bagian Kedua \\ Tujuan Pemberdayaan \\ Pasal 5
}

Tujuan pemberdayaan Usaha Mikro, Kecil, dan Menengah:

a. Mewujudkan struktur perekonomian nasional yang seimbang, berkembang, dan berkeadilan;

b. Menumbuhkan dan mengembangkan kemampuan Usaha Mikro, Kecil, dan Menengah menjadi usaha yang tangguh dan mandiri; dan 
c. Meningkatkan peran Usaha Mikro, Kecil, dan Menengah dalam pembangunan daerah, penciptaan lapangan kerja, pemerataan pendapatan, pertumbuhan ekonomi, dan pengentasan rakyat dari kemiskinan.

\section{BAB IV \\ KRITERIA}

Pasal 6

(1) Kriteria Usaha Mikro adalah sebagai berikut:

a. Memiliki kekayaan bersih paling banyak Rp50.000.000,00 (lima puluh juta rupiah) tidak termasuk tanah dan bangunan tempat usaha; atau

b. Memiliki hasil penjualan tahunan paling banyak Rp300.000.000,00 (tiga ratus juta rupiah).

(2) Kriteria Usaha Kecil adalah sebagai berikut:

a. Memiliki kekayaan bersih lebih dari Rp50.000.000,00 (lima puluh juta rupiah) sampai dengan paling banyak Rp500.000.000,00 (lima ratus juta rupiah) tidak termasuk tanah dan bangunan tempat usaha; atau

b. Memiliki hasil penjualan tahunan lebih dari Rp300.000.000,00 (tiga ratus juta rupiah) sampai dengan paling banyak Rp2.500.000.000,00 (dua milyar lima ratus juta rupiah).

(3) Kriteria Usaha Menengah adalah sebagai berikut:

a. Memiliki kekayaan bersih lebih dari Rp500.000.000,00 (lima ratus juta rupiah) sampai dengan paling banyak Rp10.000.000.000,00 (sepuluh milyar rupiah) tidak termasuk tanah dan bangunan tempat usaha; atau

b. emiliki hasil penjualan tahunan lebih dari Rp2.500.000.000,00 (dua milyar lima ratus juta rupiah) sampai dengan paling banyak Rp50.000.000.000,00 (lima puluh milyar rupiah).

(4) Kriteria sebagaimana dimaksud pada ayat (1) huruf a, huruf b, dan ayat (2) huruf a, huruf $b$, serta ayat (3) huruf a, huruf b nilai 
nominalnya dapat diubah sesuai dengan perkembangan perekonomian yang diatur dengan Peraturan Presiden. www.hukumonline.com

\section{BAB V \\ PENUMBUHAN IKLIM USAHA}

\section{Pasal 7}

(1) Pemerintah dan Pemerintah Daerah menumbuhkan Iklim Usaha dengan menetapkan peraturan perundangundangan dan kebijakan yang meliputi aspek:
a. Pendanaan;
b. Sarana dan prasarana;
c. Informasi usaha;
d. Kemitraan;
e. Perizinan usaha;
f. Kesempatan berusaha;
g. Promosi dagang; dan
h. Dukungan kelembagaan.

(2) Dunia Usaha dan masyarakat berperan serta secara aktif membantu menumbuhkan Iklim Usaha sebagaimana dimaksud pada ayat (1).

\section{Pasal 8}

Aspek pendanaan sebagaimana dimaksud dalam Pasal 7 ayat (1) huruf a ditujukan untuk:

a. Memperluas sumber pendanaan dan memfasilitasi Usaha Mikro, Kecil, dan Menengah untuk dapat mengakses kredit perbankan dan lembaga keuangan bukan bank;

b. Memperbanyak lembaga pembiayaan dan memperluas jaringannya sehingga dapat diakses oleh Usaha Mikro, Kecil, dan Menengah;

c. Memberikan kemudahan dalam memperoleh pendanaan secara cepat, tepat, murah, dan tidak diskriminatif dalam pelayanan sesuai dengan ketentuan peraturan perundang-undangan; dan 
d. Membantu para pelaku Usaha Mikro dan Usaha Kecil untuk mendapatkan pembiayaan dan jasa/produk keuangan lainnya yang disediakan oleh perbankan dan lembaga keuangan bukan bank, baik yang menggunakan sistem konvensional maupun sistem syariah dengan jaminan yang disediakan oleh Pemerintah.

\section{Pasal 9}

Aspek sarana dan prasarana sebagaimana dimaksud dalam Pasal 7 ayat (1) huruf $\mathrm{b}$ ditujukan untuk:

a. Mengadakan prasarana umum yang dapat mendorong dan mengembangkan pertumbuhan Usaha Mikro dan Kecil; dan

b. Memberikan keringanan tarif prasarana tertentu bagi Usaha Mikro dan Kecil.

\section{Pasal 10}

Aspek informasi usaha sebagaimana dimaksud dalam Pasal 7 ayat (1) huruf c ditujukan untuk:

a. Membentuk dan mempermudah pemanfaatan bank data dan jaringan informasi bisnis

b. Mengadakan dan menyebarluaskan informasi mengenai pasar, sumber pembiayaan, komoditas, penjaminan, desain dan teknologi, dan mutu; dan

c. Memberikan jaminan transparansi dan akses yang sama bagi semua pelaku Usaha Mikro, Kecil, dan Menengah atas segala informasi usaha.

\section{Pasal 11}

Aspek kemitraan sebagaimana dimaksud dalam Pasal 7 ayat (1) huruf d ditujukan untuk:

a. Mewujudkan kemitraan antar-Usaha Mikro, Kecil, dan Menengah;

b. Mewujudkan kemitraan antara Usaha Mikro, Kecil, Menengah, dan Usaha Besar; 
c. Mendorong terjadinya hubungan yang saling menguntungkan dalam pelaksanaan transaksi usaha antar- Usaha Mikro, Kecil, dan Menengah;

d. Mendorong terjadinya hubungan yang saling menguntungkan dalam pelaksanaan transaksi usaha antara Usaha Mikro, Kecil, Menengah, dan Usaha Besar;

e. Mengembangkan kerjasama untuk meningkatkan posisi tawar Usaha Mikro, Kecil, dan Menengah;

f. Mendorong terbentuknya struktur pasar yang menjamin tumbuhnya persaingan usaha yang sehat dan melindungi konsumen; dan

g. Mencegah terjadinya penguasaan pasar dan pemusatan usaha oleh orang perorangan atau kelompok tertentu yang merugikan Usaha Mikro, Kecil, dan Menengah.

\section{Pasal 12}

(1) Aspek perizinan usaha sebagaimana dimaksud dalam Pasal 7 ayat (1) huruf e ditujukan untuk:

a. Menyederhanakan tata cara dan jenis perizinan usaha dengan sistem pelayanan terpadu satu pintu; dan

b. Membebaskan biaya perizinan bagi Usaha Mikro dan memberikan keringanan biaya perizinan bagi Usaha Kecil.

(2) Ketentuan lebih lanjut mengenai persyaratan dan tata cara permohonan izin usaha diatur dengan Peraturan Pemerintah.

\section{Pasal 13}

(1) Aspek kesempatan berusaha sebagaimana dimaksud dalam Pasal 7 ayat (1) huruf $f$ ditujukan untuk:

a. Menentukan peruntukan tempat usaha yang meliputi pemberian lokasi di pasar, ruang pertokoan, lokasi sentra industri, lokasi pertanian rakyat, lokasi pertambangan rakyat, lokasi yang wajar bagi pedagang kaki lima, serta lokasi lainnya;

b. Menetapkan alokasi waktu berusaha untuk Usaha Mikro dan Kecil di subsektor perdagangan retail;

84 Ni Putu Suci Meinarni ... [et al.] 
c. Mencadangkan bidang dan jenis kegiatan usaha yang memiliki kekhususan proses, bersifat padat karya, serta mempunyai warisan budaya yang bersifat khusus dan turun-temurun;

d. Menetapkan bidang usaha yang dicadangkan untuk Usaha Mikro, Kecil, dan Menengah serta bidang usaha yang terbuka untuk Usaha Besar dengan syarat harus bekerja sama dengan Usaha Mikro, Kecil, dan Menengah;

e. Melindungi usaha tertentu yang strategis untuk Usaha Mikro, Kecil, dan Menengah;

f. Mengutamakan penggunaan produk yang dihasilkan oleh Usaha Mikro dan Kecil melalui pengadaan secara langsung;

g. Memprioritaskan pengadaan barang atau jasa dan pemborongan kerja Pemerintah dan Pemerintah Daerah; dan

h. Memberikan bantuan konsultasi hukum dan pembelaan.

(2) Pelaksanaan ketentuan sebagaimana dimaksud pada ayat (1) dilakukan pengawasan dan pengendalian oleh Pemerintah dan Pemerintah Daerah.

\section{Pasal 14}

(1) Aspek promosi dagang sebagaimana dimaksud dalam Pasal 7 ayat (1) huruf g, ditujukan untuk:

a. Meningkatkan promosi produk Usaha Mikro, Kecil, dan Menengah di dalam dan di luar negeri;

b. Memperluas sumber pendanaan untuk promosi produk Usaha Mikro, Kecil, dan Menengah di dalam dan di luar negeri;

c. Memberikan insentif dan tata cara pemberian insentif untuk Usaha Mikro, Kecil, dan Menengah yang mampu menyediakan pendanaan secara mandiri dalam kegiatan promosi produk di dalam dan di luar negeri; dan

d. Memfasilitasi pemilikan hak atas kekayaan intelektual atas produk dan desain Usaha Mikro, Kecil, dan Menengah dalam kegiatan usaha dalam negeri dan ekspor. 
(2) Pelaksanaan ketentuan sebagaimana dimaksud pada ayat (1) dilakukan pengawasan dan pengendalian oleh Pemerintah dan Pemerintah Daerah.

\section{Pasal 15}

Aspek dukungan kelembagaan sebagaimana dimaksud dalam Pasal 7 ayat (1) huruf h ditujukan untuk mengembangkan dan meningkatkan fungsi inkubator, lembaga layanan pengembangan usaha, konsultan keuangan mitra bank, dan lembaga profesi sejenis lainnya sebagai lembaga pendukung pengembangan Usaha Mikro, Kecil, dan Menengah.

\section{BAB VI \\ PENGEMBANGAN USAHA}

Pasal 16

(1) Pemerintah dan Pemerintah Daerah memfasilitasi pengembangan usaha dalam bidang:

a. Produksi dan pengolahan;

b. Pemasaran;

c. Sumber daya manusia; dan

d. Desain dan teknologi.

(2) Dunia usaha dan masyarakat berperan serta secara aktif melakukan pengembangan sebagaimana dimaksud pada ayat (1).

(3) Ketentuan lebih lanjut mengenai tatacara pengembangan, prioritas, intensitas, dan jangka waktu pengembangan diatur dengan Peraturan Pemerintah. 


\section{Pasal 17}

Pengembangan dalam bidang produksi dan pengolahan sebagaimana dimaksud dalam Pasal 16 ayat (1) huruf a dilakukan dengan cara:

a. Meningkatkan teknik produksi dan pengolahan serta kemampuan manajemen bagi Usaha Mikro, Kecil, dan Menengah;

b. Memberikan kemudahan dalam pengadaan sarana dan prasarana, produksi dan pengolahan, bahan baku, bahan penolong, dan kemasan bagi produk Usaha Mikro, Kecil, dan Menengah;

c. Mendorong penerapan standarisasi dalam proses produksi dan pengolahan; dan

d. Meningkatkan kemampuan rancang bangun dan perekayasaan bagi Usaha Menengah.

\section{Pasal 18}

Pengembangan dalam bidang pemasaran, sebagaimana dimaksud dalam Pasal 16 ayat (1) huruf b dilakukan dengan cara:

a. Melaksanakan penelitian dan pengkajian pemasaran;

b. Menyebarluaskan informasi pasar;

c. Meningkatkan kemampuan manajemen dan teknik pemasaran;

d. Menyediakan sarana pemasaran yang meliputi penyelenggaraan uji coba pasar, lembaga pemasaran, penyediaan rumah dagang, dan promosi Usaha Mikro dan Kecil;

e. Memberikan dukungan promosi produk, jaringan pemasaran, dan distribusi; dan

f. Menyediakan tenaga konsultan profesional dalam bidang pemasaran.

\section{Pasal 19}

Pengembangan dalam bidang sumber daya manusia sebagaimana dimaksud dalam Pasal 16 ayat (1) huruf c dilakukan dengan cara:

a. Memasyarakatkan dan membudayakan kewirausahaan; 
b. Meningkatkan keterampilan teknis dan manajerial; dan

c. Membentuk dan mengembangkan lembaga pendidikan dan pelatihan untuk melakukan pendidikan, pelatihan, penyuluhan, motivasi dan kreativitas bisnis, dan penciptaan wirausaha baru.

\title{
Pasal 20
}

Pengembangan dalam bidang desain dan teknologi sebagaimana dimaksud dalam Pasal 16 ayat (1) huruf d dilakukan dengan:

a. Meningkatkan kemampuan di bidang desain dan teknologi serta pengendalian mutu;

b. Meningkatkan kerjasama dan alih teknologi;

c. Meningkatkan kemampuan Usaha Kecil dan Menengah di bidang penelitian untuk mengembangkan desain dan teknologi baru;

d. Memberikan insentif kepada Usaha Mikro, Kecil, dan Menengah yang mengembangkan teknologi dan melestarikan lingkungan hidup; dan

e. Mendorong Usaha Mikro, Kecil, dan Menengah untuk memperoleh sertifikat hak atas kekayaan intelektual.

\author{
BAB VII \\ PEMBIAYAAN DAN PENJAMINAN \\ Bagian Kesatu \\ Pembiayaan dan Penjaminan Usaha Mikro dan Kecil \\ Pasal 21
}

(1) Pemerintah dan Pemerintah Daerah menyediakan pembiayaan bagi Usaha Mikro dan Kecil.

(2) Badan Usaha Milik Negara dapat menyediakan pembiayaan dari penyisihan bagian laba tahunan yang dialokasikan kepada Usaha Mikro dan Kecil dalam bentuk pemberian pinjaman, penjaminan, hibah, dan pembiayaan lainnya. 
(3) Usaha Besar nasional dan asing dapat menyediakan pembiayaan yang dialokasikan kepada Usaha Mikro dan Kecil dalam bentuk pemberian pinjaman, penjaminan, hibah, dan pembiayaan lainnya.

(4) Pemerintah, Pemerintah Daerah, dan Dunia Usaha dapat memberikan hibah, mengusahakan bantuan luar negeri, dan mengusahakan sumber pembiayaan lain yang sah serta tidak mengikat untuk Usaha Mikro dan Kecil.

(5) Pemerintah dan Pemerintah Daerah dapat memberikan insentif dalam bentuk kemudahan persyaratan perizinan, keringanan tarif sarana dan prasarana, dan bentuk insentif lainnya yang sesuai dengan ketentuan peraturan perundang-undangan kepada dunia usaha yang menyediakan pembiayaan bagi Usaha Mikro dan Kecil.

\section{Pasal 22}

Dalam rangka meningkatkan sumber pembiayaan Usaha Mikro dan Usaha Kecil, Pemerintah melakukan upaya:

a. Pengembangan sumber pembiayaan dari kredit perbankan dan lembaga keuangan bukan bank

b. Pengembangan lembaga modal ventura;

c. Pelembagaan terhadap transaksi anjak piutang;

d. Peningkatan kerjasama antara Usaha Mikro dan Usaha Kecil melalui koperasi simpan pinjam dan koperasi jasa keuangan konvensional dan syariah; dan

e. Pengembangan sumber pembiayaan lain sesuai dengan ketentuan peraturan perundang-undangan.

\section{Pasal 23}

(1) Untuk meningkatkan akses Usaha Mikro dan Kecil terhadap sumber pembiayaan sebagaimana dimaksud dalam Pasal 22, Pemerintah dan Pemerintah Daerah:

a. Menumbuhkan, mengembangkan, dan memperluas jaringan lembaga keuangan bukan bank; 
b. Menumbuhkan, mengembangkan, dan memperluas jangkauan lembaga penjamin kredit; dan

c. Memberikan kemudahan dan fasilitasi dalam memenuhi persyaratan untuk memperoleh pembiayaan.

(2) Dunia Usaha dan masyarakat berperan serta secara aktif meningkatkan akses Usaha Mikro dan Kecil terhadap pinjaman atau kredit sebagaimana dimaksud pada ayat (1) dengan cara:

a. Meningkatkan kemampuan menyusun studi kelayakan usaha;

b. Meningkatkan pengetahuan tentang prosedur pengajuan kredit atau pinjaman; dan

c. Meningkatkan pemahaman dan keterampilan teknis serta manajerial usaha.

\section{Bagian Kedua \\ Pembiayaan dan Penjaminan Usaha Menengah}

Pasal 24

Pemerintah dan Pemerintah Daerah melakukan pemberdayaan Usaha Menengah dalam bidang pembiayaan dan penjaminan dengan:

a. Memfasilitasi dan mendorong peningkatan pembiayaan modal kerja dan investasi melalui perluasan sumber dan pola pembiayaan, akses terhadap pasar modal, dan lembaga pembiayaan lainnya; dan

b. Mengembangkan lembaga penjamin kredit, dan meningkatkan fungsi lembaga penjamin ekspor.

\section{BAB VIII \\ KEMITRAAN}

Pasal 25

(1) Pemerintah, Pemerintah Daerah, Dunia Usaha, dan masyarakat memfasilitasi, mendukung, dan menstimulasi kegiatan kemitraan, yang saling membutuhkan, mempercayai, memperkuat, dan menguntungkan. 
(2) Kemitraan antar-Usaha Mikro, Kecil, dan Menengah dan Kemitraan antara Usaha Mikro, Kecil, dan Menengah dengan Usaha Besar mencakup proses alih keterampilan di bidang produksi dan pengolahan, pemasaran, permodalan, sumber daya manusia, dan teknologi.

(3) Menteri dan Menteri Teknis mengatur pemberian insentif kepada Usaha Besar yang melakukan kemitraan dengan Usaha Mikro, Kecil, dan Menengah melalui inovasi dan pengembangan produk berorientasi ekspor, penyerapan tenaga kerja, penggunaan teknologi tepat guna dan ramah lingkungan, serta menyelenggarakan pendidikan dan pelatihan.

\section{Pasal 26}

Kemitraan dilaksanakan dengan pola:
a. Inti-plasma;
b. Subkontrak;
c. Waralaba;
d. Perdagangan umum;
e. Distribusi dan keagenan; dan
f. Bentuk-bentuk kemitraan lain, seperti: bagi hasil, kerjasama operasional, usaha patungan (joint venture), dan penyumberluaran (outsourching).

\section{Pasal 27}

Pelaksanaan kemitraan dengan pola inti-plasma sebagaimana dimaksud dalam Pasal 26 huruf a, Usaha Besar sebagai inti membina dan mengembangkan Usaha Mikro, Kecil, dan Menengah, yang menjadi plasmanya dalam:

a. Penyediaan dan penyiapan lahan;

b. Penyediaan sarana produksi;

c. Pemberian bimbingan teknis produksi dan manajemen usaha;

d. Perolehan, penguasaan, dan peningkatan teknologi yang diperlukan;

e. Pembiayaan; 
f. Pemasaran;

g. Penjaminan;

h. Pemberian informasi; dan

i. Pemberian bantuan lain yang diperlukan bagi peningkatan efisiensi dan produktivitas dan wawasan usaha.

\section{Pasal 28}

Pelaksanaan kemitraan usaha dengan pola subkontrak sebagaimana dimaksud Pasal 26 huruf b, untuk memproduksi barang dan/atau jasa, Usaha Besar memberikan dukungan berupa:

a. Kesempatan untuk mengerjakan sebagian produksi dan/atau komponennya;

b. Kesempatan memperoleh bahan baku yang diproduksi secara berkesinambungan dengan jumlah dan harga yang wajar;

c. Bimbingan dan kemampuan teknis produksi atau manajemen;

d. Perolehan, penguasaan, dan peningkatan teknologi yang diperlukan;

e. Pembiayaan dan pengaturan sistem pembayaran yang tidak merugikan salah satu pihak; dan

f. Upaya untuk tidak melakukan pemutusan hubungan sepihak.

\section{Pasal 29}

(1) Usaha Besar yang memperluas usahanya dengan cara waralaba sebagaimana dimaksud dalam Pasal 26 huruf c, memberikan kesempatan dan mendahulukan Usaha Mikro, Kecil, dan Menengah yang memiliki kemampuan.

(2) Pemberi waralaba dan penerima waralaba mengutamakan penggunaan barang dan/atau bahan hasil produksi dalam negeri sepanjang memenuhi standar mutu barang dan jasa yang disediakan dan/atau dijual berdasarkan perjanjian waralaba.

(3) Pemberi waralaba wajib memberikan pembinaan dalam bentuk pelatihan, bimbingan operasional manajemen, pemasaran, penelitian, dan pengembangan kepada penerima waralaba secara berkesinambungan. 
(1) Pelaksanaan kemitraan dengan pola perdagangan umum sebagaimana dimaksud dalam Pasal 26 huruf d, dapat dilakukan dalam bentuk kerjasama pemasaran, penyediaan lokasi usaha, atau penerimaan pasokan dari Usaha Mikro, Kecil, dan Menengah oleh Usaha Besar yang dilakukan secara terbuka.

(2) Pemenuhan kebutuhan barang dan jasa yang diperlukan oleh Usaha Besar dilakukan dengan mengutamakan pengadaan hasil produksi Usaha Kecil atau Usaha Mikro sepanjang memenuhi standar mutu barang dan jasa yang diperlukan.

(3) Pengaturan sistem pembayaran dilakukan dengan tidak merugikan salah satu pihak.

\section{Pasal 31}

Dalam pelaksanaan kemitraan dengan pola distribusi dan keagenan sebagaimana dimaksud dalam Pasal 26 huruf e, Usaha Besar dan/atau Usaha Menengah memberikan hak khusus untuk memasarkan barang dan jasa kepada Usaha Mikro dan/atau Usaha Kecil.

\section{Pasal 32}

Dalam hal Usaha Mikro, Kecil, dan Menengah menyelenggarakan usaha dengan modal patungan dengan pihak asing, berlaku ketentuan sebagaimana diatur dalam peraturan perundang-undangan.

\section{Pasal 33}

Pelaksanaan kemitraan usaha yang berhasil, antara Usaha Besar dengan Usaha Mikro, Kecil, dan Menengah dapat ditindaklanjuti dengan kesempatan pemilikan saham Usaha Besar oleh Usaha Mikro, Kecil, dan Menengah. 
(1) Perjanjian kemitraan dituangkan dalam perjanjian tertulis yang sekurang-kurangnya mengatur kegiatan usaha, hak dan kewajiban masing-masing pihak, bentuk pengembangan, jangka waktu, dan penyelesaian perselisihan.

(2) Perjanjian kemitraan sebagaimana dimaksud pada ayat (1) dilaporkan kepada pihak yang berwenang sesuai dengan ketentuan peraturan perundang-undangan.

(3) Perjanjian kemitraan sebagaimana dimaksud pada ayat (1) tidak boleh bertentangan dengan prinsip dasar kemandirian Usaha Mikro, Kecil, dan Menengah serta tidak menciptakan ketergantungan Usaha Mikro, Kecil, dan Menengah terhadap Usaha Besar.

(4) Untuk memantau pelaksanaan kemitraan sebagaimana dimaksud pada ayat (1) dan (2), Menteri dapat membentuk lembaga koordinasi kemitraan usaha nasional dan daerah.

\section{Pasal 35}

(1) Usaha Besar dilarang memiliki dan/atau menguasai Usaha Mikro, Kecil, dan/atau Menengah sebagai mitra usahanya dalam pelaksanaan hubungan kemitraan sebagaimana dimaksud dalam Pasal 26.

(2) Usaha Menengah dilarang memiliki dan/atau menguasai Usaha Mikro dan/atau Usaha Kecil mitra usahanya.

\section{Pasal 36}

(1) Dalam melaksanakan kemitraan sebagaimana dimaksud dalam Pasal 26 para pihak mempunyai kedudukan hukum yang setara dan terhadap mereka berlaku hukum Indonesia.

(2) Pelaksanaan kemitraan diawasi secara tertib dan teratur oleh lembaga yang dibentuk dan bertugas untuk.com mengawasi persaingan usaha sebagaimana diatur dalam peraturan perundang-undangan.

94 Ni Putu Suci Meinarni ... [et al.] 
Pasal 37

Ketentuan lebih lanjut mengenai pola kemitraan sebagaimana dimaksud dalam Pasal 26 diatur dengan Peraturan Pemerintah.

\title{
BAB IX \\ KOORDINASI DAN PENGENDALIAN PEMBERDAYAAN USAHA MIKRO, KECIL, DAN MENENGAH
}

\section{Pasal 38}

(1) Menteri melaksanakan koordinasi dan pengendalian pemberdayaan Usaha Mikro, Kecil, dan Menengah.

(2) Koordinasi dan pengendalian pemberdayaan Usaha Mikro, Kecil, dan Menengah sebagaimana dimaksud pada ayat (1) dilaksanakan secara nasional dan daerah yang meliputi: penyusunan dan pengintegrasian kebijakan dan program, pelaksanaan, pemantauan, evaluasi, serta pengendalian umum terhadap pelaksanaan pemberdayaan Usaha Mikro, Kecil, dan Menengah, termasuk penyelenggaraan kemitraan usaha dan pembiayaan Usaha Mikro, Kecil, dan Menengah.

(3) Ketentuan lebih lanjut mengenai penyelenggaraan koordinasi dan pengendalian pemberdayaan Usaha Mikro, Kecil, dan Menengah diatur dengan Peraturan Pemerintah.

\section{BAB X \\ SANKSI ADMINISTRATIF DAN KETENTUAN PIDANA}

\author{
Bagian Kesatu \\ Sanksi Administratif \\ Pasal 39
}

(1) Usaha Besar yang melanggar ketentuan Pasal 35 ayat (1) dikenakan sanksi administratif berupa pencabutan izin usaha dan/atau denda paling banyak Rp10.000.000.000,00 (sepuluh milyar rupiah) oleh instansi yang berwenang. 
(2) Usaha Menengah yang melanggar ketentuan Pasal 35 ayat (2) dikenakan sanksi administratif berupa pencabutan izin usaha dan/atau denda paling banyak Rp 5.000.000.000,00 (lima milyar rupiah) oleh instansi yang berwenang.

(3) Ketentuan lebih lanjut mengenai tata cara pemberian sanksi administratif sebagaimana dimaksud pada ayat (1) dan ayat (2) diatur dengan Peraturan Pemerintah.

\section{Bagian Kedua \\ Ketentuan Pidana \\ Pasal 40}

Setiap orang yang menguntungkan diri sendiri atau orang lain dengan mengaku atau memakai nama Usaha Mikro, Kecil, dan Menengah sehingga mendapatkan kemudahan untuk memperoleh dana, tempat usaha, bidang dan kegiatan usaha, atau pengadaan barang dan jasa untuk pemerintah yang diperuntukkan bagi Usaha Mikro, Kecil, dan Menengah dipidana dengan pidana penjara paling lama 5 (lima) tahun dan pidana denda paling banyak Rp10.000.000.000,00 (sepuluh milyar rupiah).

\section{BAB XI \\ KETENTUAN PENUTUP \\ Pasal 41}

Peraturan Pemerintah sebagai pelaksanaan Undang-Undang ini ditetapkan paling lambat 12 (dua belas) bulan atau 1 (satu) tahun sejak UndangUndang ini diundangkan.

\section{Pasal 42}

Pada saat Undang-Undang ini mulai berlaku, Undang-Undang Republik Indonesia Nomor 9 tahun 1995 tentang Usaha Kecil (Lembaran Negara Republik Indonesia Tahun 1995 Nomor 74, Tambahan Lembaran Negara Tahun 1995 Nomor 3611) dicabut dan dinyatakan tidak berlaku. 


\section{Pasal 43}

Pada saat Undang-Undang ini mulai berlaku, semua peraturan perundangundangan yang berkaitan dengan Usaha Kecil dan Menengah dinyatakan masih berlaku sepanjang tidak bertentangan dengan ketentuan dalam Undang-Undang ini.

\section{Pasal 44}

Undang-Undang ini mulai berlaku pada tanggal diundangkan. Agar setiap orang mengetahuinya, memerintahkan pengundangan Undang-Undang ini dengan penempatannya dalam Lembaran Negara Republik Indonesia.

Disahkan Di Jakarta,

Pada Tanggal 4 Juli 2008

Presiden Republik Indonesia,

Ttd.

Dr. H. Susilo Bambang Yudhoyono

Diundangkan Di Jakarta,

Pada Tanggal 4 Juli 2008

Menteri Hukum Dan Hak Asasi Manusia

Republik Indonesia,

Ttd.

Andi Mattalatta

Lembaran Negara Republik Indonesia Tahun 2008 Nomor 93

Salinan Sesuai Dengan Aslinya

Sekretariat Negara Ri

Kepala Biro Peraturan

Perundang-Undangan

Bidang Perekonomian Dan Industri,

Setio Sapto Nugroho 


\section{PROFL PENUUS}

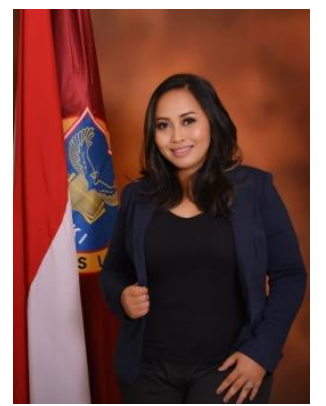

Ni Putu Suci Meinarni, S.H., LL.M., Penulis yang lahir di Tabanan - Bali, 17 Mei 1985 ini adalah dosen di STMIK STIKOM Indonesia. Memulai karir pada dunia akademik pada tahun 2015 adalah hal yang cukup menantang bagi penulis, karena tidak pernah menyangka sebelumnya untuk mengabdikan diri menjadi seorang dosen. Penulis memperoleh gelar sarjana hukum $(\mathrm{SH})$ di Universitas Udayana Denpasar tahun 2008 dan gelar LLM (Master of Law) di Universitas Gadjahmada Yogyakarta tahun 2013. Pada tahun 2004, penulis pernah mewakili Universitas Udayana untuk mengikuti program pertukaran pelajar kultural dengan Hyogo University, Jepang. Saat ini penulis mengajar beberapa mata kuliah yang berkaitan dengan etika dunia maya dan juga menikmati aktivitas sebagai peneliti di bidang ilmu sosial dan hukum dunia maya.

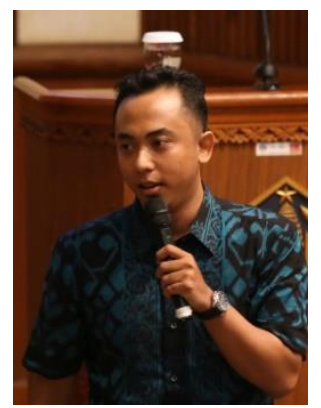

Ida Bagus Ari Indra Iswara, S.Kom., M.Kom., Merupakan anak terakhir dari keluarga yang terlahir di sebuah kota yang sejuk di tengah-tengah pulau Bali. Pendidikan dimulai dari SD-SMA di kota bangli, kemudian melanjutkan ke jenjang sarjana di jurusan ilmu komputer di universitas udayana tahun 2006-2010. Rehat sejenak untuk belajar mengajar di kampus ilmu komputer universitas udayana sampai diberikan beasiswa S2 ke ITS surabaya di jurusan Teknik Informatika dari tahun 2011-2013. Saat ini aktif mengajar di bidang teknik informatika dan juga sering diundang untuk menjadi saksi ahli bidang teknik informatika. Selain itu saat ini juga aktif di Relawan Jurnal Indonesia, dan beberapa organisasi akademis lainya. 


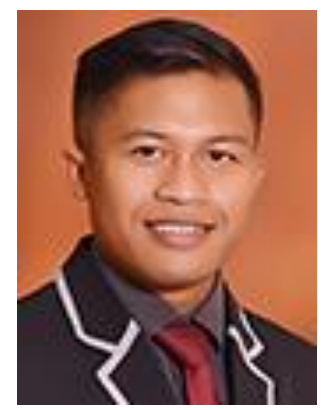

I Nyoman Saputra Wahyu Wijaya, S.Kom., M.Cs., merupakan kelahiran Denpasar, 26 Oktober 1989. Saat ini mengabdikan diri di Universitas Pendidikan Ganesha sebagai Dosen Ilmu Komputer. Sempat mengenyam pendidikan S1 di jurusan Ilmu komputer Universitas Udayana tahun 2007 dan melanjutkan pendidikan S2 di jurusan Ilmu Komputer Universitas Gadjah Mada pada tahun 2012. Memulai karier sebagai seorang dosen di STMIK STIKOM Indonesia tahun 2015 hingga tahun 2019. Saat ini penulis berkesempatan mengampu mata kuliah basis data, sistem digital, dan struktur data.

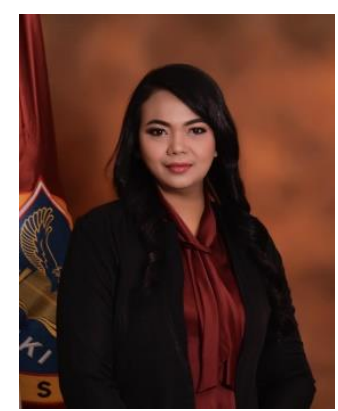

Ayu Gede Willdahlia, S.E., M.M., Lahir di Jimbaran tanggal 28 September 1981. Menyelesaikan pendidikan Magister Manajemen di Universitas Warmadewa. Pengalaman bekerja sebagai penyiar radio swasta di Bali dan menjadi Master Of Ceremony mengantarkan penulis untuk menggali potensi yang dimiliki. Saat ini penulis merupakan seorang Dosen di STMIK STIKOM Indonesia Bali serta menjadi seorang fasilitator, pembicara dalam pelatihan-pelatihan dan workshop diantaranya yang mengangkat topik Presenting your professional Image, Service Excellent, Digital Marketing, Managing Conflict dan 7 Habits. 